\author{
Universidade de São Paulo \\ Faculdade de Filosofia, Letras e Ciências Humanas \\ Departamento de Filosofia \\ Programa de Pós-Graduação em Filosofia
}

Andre Scoralick

\title{
Paixão, Liberdade e Conveniência em dois ensaios de Montaigne (Da vaidade e De poupar a própria vontade)
}




\section{Paixão, Liberdade e Conveniência em dois ensaios de Montaigne (Da vaidade e De poupar a própria vontade)}

Tese apresentada ao Programa de Pós-Graduação em Filosofia, do Departamento de Filosofia da Faculdade de Filosofia, Letras e Ciências Humanas da Universidade de São Paulo, para obtenção do título de Doutor em Filosofia, sob a orientação do Prof. Dr. Sérgio Cardoso

São Paulo 2013 


\section{AGRADECIMENTOS}

À Glaucia, meu amor, pelo imenso apoio e profundo carinho, sem os quais este trabalho não teria sido realizado.

Aos meus pais, a quem tudo devo: o que sou e o que posso.

À CNPq, pelo apoio e financiamento.

À Marie, Maria Helena, Roseli, Luciana, Geni e Verônica, da Secretaria do Departamento de Filosofia, pelo auxílio e atenção.

Ao Prof. Dr. Roberto Bolzani e ao Prof. Dr. Luiz Eva, pelas valiosas contribuições que suas argüições, em minha qualificação, trouxeram para este estudo.

Ao Edson Querubini, pela leitura atenta de todo o estudo, pelas sugestões e correções que deram alguma consistência a este trabalho.

E, muito especialmente, ao Prof. Dr. Sérgio Cardoso, pela orientação meticulosa, profunda atenção e generosidade incomensurável. 


\section{RESUMO}

SCORALICK, A. Paixão, Liberdade e Conveniência em dois ensaios de Montaigne (Da vaidade e De poupar a própria vontade). 2013. 142 f. Tese (Doutorado) - Faculdade de Filosofia, Letras e Ciências Humanas. Departamento de Filosofia, Universidade de São Paulo, São Paulo, 2013

O presente estudo pretende oferecer uma interpretação da reflexão moral de Montaigne que se opõe àquelas que a vêem centrada na alegação da passividade do ensaísta, reduzindo-a à prescrição de uma subordinação pragmática às leis e aos costumes e fazendo dos Ensaios uma mera descrição da condição humana. Através da leitura daqueles ensaios em que Montaigne mais parece passivo (nos quais tais interpretações justamente apóiam suas hipóteses), acreditamos encontrar os modos de operação de uma ação discreta, pautada pela exigência de adequação aos objetos e às circunstâncias,

uma ação que abre espaço para o livre jogo das paixões segundo a conveniência. Espera-se, com isso, resgatar a dimensão normativa dos Ensaios, seja lançando luz sobre as preocupações permanentes do autor com a própria liberdade (sempre ameaçada pelo risco da servidão aos afetos), seja chamando a atenção dos leitores para o Montaigne político, atento aos riscos que a ambição, as inovações e os "remédios extremos" (a perfídia) trazem para ordem pública e, ao mesmo tempo, ocupado em sugerir (através do exemplo de seus mandatos à frente da mairie de Bordeaux) parâmetros para uma ação política discreta.

\section{Palavras-chave}

Montaigne; ética montaigniana; passividade; paixão; liberdade; conveniência. 


\begin{abstract}
SCORALICK, A. Passion, Freedom and Convenience in two essays of Montaigne (Of vanity and Of managing the will). Faculdade de Filosofia, Letras e Ciências Humanas, Departamento de Filosofia, Universidade de São Paulo, 2013. Thesis.

The present study has the purpose of responding to the commentators who interpret Michel de Montaigne's thought under the key of passivity and see a complete absence of an ethics on the essays and reduce all montaigniana morality to a pragmatic subordination to the laws and costumes, and also seeing the Essays as a mere description of the human condition. Reading the essays in which Montaigne's passivity seems attain his higher level (where such commentaries exactly base their hypotheses on) we sought to find the operating ways of a discreet action, ruled by that the objects and their circumstances impose; an action in which passions are gladly admitted only when it is convenient. We expect here to recover the Essays' normative dimension, be it through shedding light on the author's permanent concern with his own freedom (always threatened by the risk of the servitude to affections), be it drawing the readers' attention to the politician Montaigne, aware of the risks that ambition, innovations and "grievous remedies" (the perfidy) bring to the public order and, at the same time, able to suggest (through the example of his mandates ahead of mairie de Bordeaux) some patterns for a discreet political action.
\end{abstract}

\title{
Keywords
}

Montaigne, passivity; passion; liberty; convenience 
Capítulo 1 - Da inconstância aparente à ação conveniente (Da vaidade, III, 9)

1. Montaigne: figura da inconstância? 09

2. Sêneca e a crítica da inconstância. A indiferença do sábio. 16

3. Vaidade do modelo do sábio. As paixões como realidade incontornável. 25

4. O risco da servidão. Montaigne e a defesa da liberdade. 31

5. Senso de conveniência e concessão oportuna às paixões. 37

a. Conveniência na administração da casa. 39

b. Conveniência na política. 44

i. Crítica das iniciativas reformistas. 47

ii. Crítica da perfídia. 56

iii. Cosmopolitismo sem universalismo. 64

c. A conveniência na proximidade da morte. Crítica dos rituais de despedida.

6. Recusa da autarquia estóica. Conhecer e lidar com os próprios condicionamentos.

Cap. 2 - 'A difícil arte de deslizar sobre o mundo' ou 'Montaigne, um político discreto' (De poupar a própria vontade, III, 10)

1. Crítica da Servidão às Paixões e Prescrição de uma Terapia 85

2. Circunscrição ao Campo Político. A Justa Medida do Amor de Si. 88

3. Afastar a Paixão em nome da Ação. 90

4. Economia dos Desejos e Aspirações. Os Costumes como Medida. 91

5. A Política como Teatro. Recusa do Partidarismo sem Crítica. 93

6. A Terapia das Paixões. O Momento Oportuno. Diversão versus Patientia. 97

7. Origem vã das disputas e desfechos vergonhosos 101

8. Prestação de Contas e Crítica da Ambição: o Tato Político de Montaigne 104

9. Uma Ambição Morna e Discreta 108

$\begin{array}{lr}\text { 10. Montaigne Agente } & 110\end{array}$

$\begin{array}{lr}\text { Conclusão } & 113\end{array}$

$\begin{array}{ll}\text { Referências Bibliográficas } & 126\end{array}$ 


\section{Introdução}

O presente estudo tem como objetivo compreender a relação entre paixão e liberdade nos Ensaios de Montaigne. Nele, procuraremos responder a toda uma série de comentadores que interpretam o pensamento do ensaísta pela chave da passividade, seja vendo nos Ensaios a completa ausência de uma ética e reduzindo toda moralidade a uma subordinação pragmática dos indivíduos às leis e costumes, seja encontrando neles uma ética ora classificada como naturalista, ora como irracionalista, e fazendo de Montaigne uma espécie de paladino da autenticidade. Trata-se particularmente de uma certa linhagem do comentário montaigniano, que vem desde intérpretes clássicos como Villey, Auerbach e Friedrich e chega a comentadores contemporâneos, como Brahami.

De maneira geral, tais intérpretes levam ao extremo a crítica cética montaigniana, fazem terra arrasada de toda forma de racionalidade, e a partir daí entendem ou (como Villey) que a crítica da razão dá lugar a uma ética de cunho naturalista - fundada sobre os sentidos e a experiência - e que prescreve a moderação das paixões como a via "natural" (em oposição ao idealismo e ao artificialismo da impassibilidade que os estóicos do período imperial pretendiam fundar sobre a razão), ou (como Auerbach, Friedrich e Brahami) que não há mais a possibilidade de uma ética, não havendo mais qualquer acesso à natureza nem qualquer resquício de racionalidade que servisse de fonte normativa, de tal forma que o projeto levado a cabo pelos Ensaios terminaria sendo puramente descritivo (uma descrição da condição humana) e todo o problema das condutas na vida prática seria solucionado por meio de um acordo pragmático dos indivíduos com as leis e os costumes. 
No que diz respeito a Villey, procuraremos mostrar que, embora este grande comentador tenha sido um dos primeiros intérpretes contemporâneos a identificar com clareza a oposição montaigniana à 'extirpação' das paixões (à impassibilidade pretendida pelo sábio estóico), bem como a via alternativa que o ensaísta propõe para lidarmos com as mesmas (a moderação e a terapia do desvio), e embora sua interpretação dos Ensaios preserve a possibilidade de uma ética, a caracterização e a descrição que dela Villey nos oferece padece de muitas dificuldades, seja por referi-la imediatamente à natureza (o que parece questionável num autor que dá grande peso aos costumes), seja por apoiá-la, sem mais, na sensibilidade e na experiência, afastando toda e qualquer forma de racionalidade das estratégias montaignianas sobre as paixões.

Na perspectiva de Villey, tudo se passa como se Montaigne, ao propor a moderação e o desvio como terapias das paixões, buscasse adequar o seu comportamento aos mandamentos da natureza. Sabemos, no entanto, que não apenas a crítica da razão, mas mesmo a crítica dos sentidos levada a cabo na Apologia a Raymond Sebond, põem em xeque qualquer pretensão de acesso a tais mandamentos. Quando Villey propõe sua ética naturalista de base empírica, ele leva em conta a crítica da razão mas ignora a crítica dos sentidos e da experiência. Ignora igualmente o papel determinante que os costumes têm nos Ensaios, isto é, o fato de que os usos conformam de tal maneira os impulsos dos indivíduos que se torna impossível discernir o que é natural e o que é costumeiro. Sobre este ponto, algumas leituras mais recentes vão ainda mais longe, recusando toda e qualquer substrato natural às condutas humanas, que seriam determinadas pelos costumes desde o nascimento dos indivíduos. 
Villey, acreditamos, leva longe demais a crítica da razão conduzida por Montaigne na Apologia e, inversamente, faz uma aposta grande demais nos sentidos e na experiência, como se a terapia que o ensaísta opõe à impassibilidade estóica fosse destituída de quaisquer elementos racionais e Montaigne se reduzisse a uma espécie de sensualista. Sem dúvida, a crítica da razão conduzida pelo autor vai ao limite da desqualificação de toda e qualquer pretensão de se elaborar uma ciência, mas não põe a perder toda e qualquer forma de racionalidade, ao menos não a razão discursiva, justamente a que permite a Montaigne fazer a crítica das pretensões da ciência, bem como, depois dela, continuar a pensar e a buscar, em meio às diferentes doutrinas legadas pela tradição, caminhos e estratégias para a conduta moral. Mais do que isso, a própria terapia que Montaigne formula para fazer frente aos excessos das paixões depende da atuação desta razão discursiva, pois é por meio dela que o ensaísta constrói as representações com auxílio das quais procurar afastar as (desviar-se das) phantasíai que despertam nele os afetos excessivos.

Enfim, pensamos que Villey descreve de maneira insuficiente a terapia montaigniana das paixões. O comentador fala em "moderação" e "desvio" de maneira relativamente vaga. Ao longo do presente trabalho, procuraremos nos aproximar de uma descrição um pouco mais precisa desta terapia. Percebemos que a tarefa supõe o aprofundamento do trabalho de identificação das fontes iniciado por Villey; sobretudo, requer um cuidado ainda maior no mapeamento dos conceitos assimilados e das noções criticadas pelo ensaísta. Apesar do enorme valor do seu trabalho pioneiro de identificação das fontes dos Ensaios, o comentador frequentemente simplifica as doutrinas (e a relação que 
Montaigne mantém com as mesmas) em nome do seu esquema evolucionista (por exemplo, fazendo do estoicismo um racionalismo não-naturalista e destituindo a moderação dos peripatéticos de qualquer fundo racional - fazendo dela uma terapia 'natural'). Ocorre que Montaigne jamais endossa ou recusa uma escola filosófica em bloco. Procuraremos mostrar como no "último" Montaigne (o cético e simpático a uma afetividade moderada) ainda sobrevivem certos esquemas estóicos (ainda que puramente formais e destituídos de qualquer fundo físico e epistemológico). Talvez uma investigação minuciosa do primeiro livro dos Ensaios possa mostrar (ainda contra o esquema evolucionista simplificador de Villey) que já existem ali indícios da tensão (que Villey restringe ao terceiro livro) entre o ensaísta e a impassibilidade do sábio estóico.

Nossa divergência em relação às posições de Villey, no entanto, é pequena se comparada à que nos opõe aos comentadores que vêem nos Ensaios uma obra meramente descritiva, na qual não haveria sequer o esboço de uma ética (tornada impossível pela crítica montaigniana da razão) e que manteria como horizonte de regulação das condutas apenas as leis e os costumes endossados pragmaticamente pelos indivíduos. Mais uma vez, referimo-nos a alguns dos mais importantes comentadores dos Ensaios, como Auerbach, Friedrich e seus sucessores mais recentes. Sem dúvida, reconhecemos o imenso valor dos trabalhos destes dois comentadores, a importância do aprofundamento que Auerbach deu à discussão em torno do tema da pintura de si e a enorme contribuição deste verdadeiro monumento de erudição que é a obra de Friedrich, que analisa uma grande quantidade de ensaios e retira daí uma visão bastante coerente do conjunto da obra. Apesar 
disso, encontramos algumas dificuldades nas duas interpretações. Especialmente, entendemos que a crítica da razão empreendida por Montaigne na Apologia não põe a perder a possibilidade de uma ética, nem faz dos Ensaios uma obra puramente descritiva e de Montaigne uma figura da passividade (do 'deixar correr' os próprios impulsos, que seriam moderados aqui e ali apenas por uma necessidade pragmática). Isto porque, se a crítica da razão veda toda a possibilidade de uma ciência moral, ela abre espaço para o poder normativo da tradição - e não apenas dos costumes, mas também de toda a tradição da filosofia moral, das diferentes escolas e doutrinas éticas (evidentemente, não mais tomadas pelo ensaísta na forma da autoridade portadora da verdade, mas na forma de um conjunto de opiniões reputadas, que cabe ao indivíduo receber e fazer passar pelo crivo da razão discursiva, que lhe permitirá encontrar neste material os parâmetros de conduta mais adequados).

É o que nós vemos nos Ensaios: um estreito diálogo entre a experiência que Montaigne faz de si mesmo e as opiniões reputadas das diferentes doutrinas de filosofia moral legadas pela tradição. Com base nele, Montaigne ensaia um éthos. Sem dúvida, um éthos medíocre, que permanece abaixo do nível do sábio virtuoso, não pretendendo se alçar à indiferença ou à fortaleza (ideais que ele percebe distantes demais de suas forças), mas que nem por isso deve ser identificado ao vulgo (à massa dos homens passivos ambiciosos, cruéis, pérfidos, mesquinhos etc.). Montaigne busca a posição do homem médio, isto é, do homem de bem que ocupa um lugar entre o sábio (que jamais é arrastado pelas paixões e que aparece no mundo de tempos em tempos - um Sócrates, por exemplo) e a grande massa dos apaixonados ("le 
commun des hommes", diz o ensaísta). Ele é o homem que luta pela própria liberdade, que até mesmo já conquistou uma certa distância em relação aos próprios afetos (já tendo aprendido a lidar com eles), mas ainda erra aqui e ali. É o homem, enfim, que ainda é afetado pela tristeza, pelo medo, pela cólera, mas que sempre se ergue e luta de novo contra a servidão das paixões, recorrendo à terapia que a tradição e a experiência de si mostraram-Ihe ser a mais adequada à sua fragilidade.

Ao ensaiar este éthos, Montaigne ensaia uma ética; e convida o leitor a fazer o mesmo, sugerindo-Ihe que faça a experiência de si e veja se se reconhece tal como ele (um homem medíocre), e se eventualmente encontra em sua terapia das paixões um caminho que também lhe sirva. Montaigne não toma a posição do mestre ou do exemplo, pois não alcançou (nem jamais alcançará) o lugar que o permita fazê-lo (o posto do homem acabado, completo, perfeito). Mas sua terapia (seu exercício, seus ensaios) não deixa de ser exemplar. É isto que o seu leitor pode imitar: seu esforço dramático - que é, ele próprio, belo e bom. Isto é ser um homem de bem: errar, acertar, tentar de novo; enfim, ensaiar.

Ao longo dos capítulos em que analisaremos os ensaios Da vaidade e De poupar a própria vontade procuraremos justamente reconstituir o trajeto montaigniano em busca da própria liberdade, bem como o convite muito discreto que faz ao leitor para que o siga. A escolha destes ensaios tem em vista seu caráter exemplar, pois desejamos mostrar, aí mesmo onde Auerbach, Friedrich e seus sucessores só vêem passividade (a saber, em dois dos últimos ensaios, escritos muito depois da crítica da razão), todo o esforço montaigniano para não se deixar levar pelas paixões. Da vaidade e De poupar a própria 
vontade são particularmente importantes para este propósito porque são justamente os ensaios em que Montaigne pode parecer mais passivo.

No primeiro deles (III, 9), como veremos, o ensaísta é acusado de negligência na administração da casa, de imprudência por, velho e doente, fazer longas viagens, de covardia e de falta de patriotismo por deixar o país em plena guerra civil. Tudo se passa como se Montaigne, ao se lançar em viagem, visasse apenas o próprio prazer e o alívio do sofrimento. Tudo se passa como se ele fosse movido unicamente por seus afetos. No segundo ensaio (III, 10), a mesma crítica. Desta vez, no entanto, referida aos mandatos do ensaísta frente à prefeitura de Bordeaux. Montaigne novamente é acusado de preguiça e de negligência; de não ter se esforçado pelo bem da cidade; de não ter deixado nenhum feito marcante que tivesse ficado na memória de seus concidadãos. Ocorre que num e noutro ensaio Montaigne mostra aos seus acusadores que, longe de simplesmente deixar-se levar de maneira passiva por seus afetos, ele obedece a um senso de conveniência que discerne as ocasiões em que é pertinente conceder espaço às pulsões (como é o caso do amor às viagens no ensaio Da vaidade) e que se pauta por exigências éticas e políticas.

Em ambos os ensaios, de fato, a opção do autor pela discrição e pelo distanciamento visa não apenas assegurar a sua própria liberdade como também o estreitamento dos laços entre os membros das diferentes coletividades das quais ele se reconhece partícipe (a casa, a cidade, o país); ela visa a manutenção da ordem frágil que não deve ser quebrada pela ação indiscreta, pelo desejo de deixar feitos na história, nem (no registro da casa) pelo desejo de acumular riquezas, ganhar cada vez mais e perder cada vez menos. Ambição e cupidez: paixões que escravizam o indivíduo e desfazem os 
laços da família, na qual a desconfiança se vê instaurada, e da sociedade, perturbada pelas inovações trazidas pelos que querem se destacar e entrar para a história.

Em suma, procuraremos compreender no presente trabalho um dos pontos centrais da ética e da política montaignianas, a relação entre paixão e liberdade, problema clássico retomado pelo autor e cuja solução faz dele, muito longe de uma figura da passividade, um homem de ação, mas de uma ação discreta. 


\section{Cap. 1 - Da inconstância aparente à ação conveniente (Da vaidade, III, 9) ${ }^{1}$}

\section{Montaigne: figura da inconstância?}

Todos os leitores dos Ensaios conhecem bem as inúmeras passagens nas quais o autor confessa sua dificuldade de suportar os sofrimentos físicos e morais; também conhecem os diversos trechos em que ele declara sua incapacidade de fazer frente às pressões dos apetites: "Ceux qui doivent avoir soing de moy pourroyent à bon marché me desrober ce qu'ils pensent m'estre nuisible: car en telles choses, je ne desire jamais ny ne trouve à dire ce que je ne vois pas; mais aussi de celles qui se presentent, ils perdent leur temps de m'en prescher l'abstinence". (III, 13, 1101). Um dos ensaios em que este gênero de passagens é mais abundante é o nono capítulo do livro terceiro - Da vaidade. Neste texto, Montaigne chega a fazer destes traços de personalidade o fio condutor de suas reflexões, construindo o ensaio sobre a vaidade em torno das razões pelas quais deixa sua casa e seu país e parte em viagem. Tais razões, ele nos mostra, são certos sofrimentos de ordem moral e as pressões da curiosidade e do desejo. O próprio Montaigne nos diz o quanto the atormentam as pressões da administração da casa e os vícios dos franceses de seu tempo: "Je me destourne volontiers du gouvernement de ma maison." (III, 9, 948) "L'autre cause qui me convie à ces promenades, c'est la disconvenance aux meurs presentes de nostre estat." (III, 9, 956). Também nos conta o quanto the agradam as viagens, os novos lugares a conhecer, os

\footnotetext{
${ }^{1}$ Utilizamos como fonte das citações dos Ensaios a edição Villey-Saulnier. Nas referências aos Ensaios, o algarismo romano refere-se ao livro e os algarismos arábicos referem-se em sequência ao capítulo e à página da edição de Villey.
} 
diferentes cenários e, principalmente, a diversidade dos costumes: "Cette humeur avide des choses nouvelles et inconnues ayde bien à nourrir en moy le desir de voyager" (III, 9, 948). Atormentado pelos sofrimentos que encontra em casa e no seu país e pressionado pelo desejo e a curiosidade, Montaigne cede: deixa para trás seu castelo e as fronteiras da França e se lança no mundo, em busca de tranquilidade e satisfação.

As pressões da casa são inúmeras. Em todos os seus papéis (o de senhor, de proprietário rural, de administrador dos bens e títulos, de gestor das finanças) Montaigne encontra motivos de perturbação, desgostos, incômodos, dificuldades. A administração da casa é uma fonte inesgotável de preocupações, que vêm de todos os lados: "tantost l'indigence et oppression de vostre peuple, tantost la querelle d'entre vos voisins, tantost l'usurpation qu'ils font sur vous, vous afflige" (III, 9, 948). As pressões também advêm dos cuidados que os cultivos exigem deste proprietário rural, como ele alega com o apoio de Horácio:

"Aut verberatae grandine vineae, Fundusque mendax, arbore nunc aquas Culpante, nunc torrentia agros Sidera, nunc hyemes iniquas;" (III, 9, 948. Versos extraídos das Odes, I, 29.)

Também é necessário administrar os bens, fazer o levantamento dos títulos e das propriedades, organizar e cuidar dos negócios: "Que ne feroy je plustost que de lire un contract, et plutost que d'aller secouant ces paperasses poudreuses, serf de mes negoces?" (III, 9, 953) É preciso gerir as 
finanças, fazer o levantamento das receitas e controlar os gastos; é necessário vigiar, entre os seus servos, os potenciais gatunos - tarefa que incomoda particularmente Montaigne, que prefere tolerar os pequenos furtos a se desgastar com uma vigilância constante: "J'oi plus volontiers dire, au bout de deux mois, que j'ai despandu quatre çens escus, que d'avoir les oreilles battues tous les soirs de trois, cinq, sept" (III, 9, 953). Por mais que tente se furtar, os problemas o assediam: "Je me desrobe aux occasions de me fascher, et me destourne de la connoissance des choses qui vont mal; et si ne puis tant faire, qu'à toute heure je ne heurte chez moy en quelque rencontre qui me desplaise." (III, 9, 950) "Il y a tousjours quelque piece qui va de travers", ele acrescenta. O peso de tantas responsabilidades é massacrante: "Je suis, chez moy, respondant de tout ce qui va mal" (III, 9, 954); "C'est pitié d'estre en lieu où tout ce que vous voyez vous enbesongne et vous concerne" (951). E sequer os prazeres da vida de Seigneur, que poderiam aliviar-Ihe as pressões, agradam-Ihe: "ny ce plaisir de bastir qu'on dict estre si attrayant, ny la chasse, ny les jardins, ny ces autres plaisirs de la vie retirée, ne me peuvent beaucoup amuser" (III, 9, 951) "Il y a quelque commodité à commander (...) et à estre obey des siens; mais c'est un plaisir trop uniforme et languissant" (III, 9, 948). Para Montaigne, a gestão da casa representa apenas perturbação: "Ces ordinaires goutieres me mangent" (III, 9, 951). São sofrimentos morais que o pressionam a deixar para trás a casa e partir em viagem: "Tant y a que le dommage qui vient de mon absence ne me semble point meriter, pendant que j'auray dequoy le porter, que je refuse d'accepter les occasions qui se presentent de me distraire de cette assistance penible" (III, 9, 950). 
Mas, há motivos ainda mais fortes para que se afaste não apenas da casa, mas até mesmo de seu país: o espetáculo horrendo dos assassinatos, das traições e dos atos cruéis que ele vê grassarem livremente entre seus conterrâneos no contexto da guerra civil que assola a França: "Je vois, non une action, ou trois, ou cent, mais des meurs en usage commun et reçeu si monstrueuses en inhumanité sur tout et desloyauté, qui est pour moy la pire espece des vices, que je n'ay point le courage de les concevoir sans horreur; et les admire quasi autant que je les desteste" (III, 9, 956). A degradação geral dos costumes causa-Ihe espanto e horror: "J'en suis en particulier trop pressé" (III, 9, 956). Em meio a tal quadro, a perda dos poucos homens de bem do país, vítimas de traição, adquire traços ainda mais perturbadores: "Le bon monsieur de Pibrac que nous venons de perdre: un esprit si gentil, les opinions si saines, les meurs si douces. Cette perte, et celle (...) de monsieur de Foix (...) je ne sçay s'il reste à la France dequoy substituer un autre coupple pareil à ces deux (...). C'estoyent ames diversement belles (...) Mais qui les avoit logées en cet aage, si disconvenables et si disproportionnées à nostre corruption et à nos tempestes?" (III, 9, 957) Sobretudo, perturba Montaigne o avanço descontrolado da perfídia ("la pire espece des vices"), que deixa de ser exceção para se tornar regra, costume geralmente aceito. $\mathrm{O}$ fim do respeito à palavra dada - a fides, fundamento último da vida social - aponta para a morte iminente do Estado: "Ce qui me poise le plus, c'est (...) que le plus voysin mal qui nous menace n'est pas alteration en la masse entiere et solide, mais sa dissipation et divulsion; l'extreme de noz craintes" (III, 9, 961-2). Também põe em risco a vida do próprio Montaigne, que também poderia ser traído e assassinado como seus amigos (também nobres e católicos) Pibrac e De Foix: 
"les invasions et incursions contraires et alternations et vicissitudes de la fortune autour de moy ont jusqu'à cette heure plus exasperé que amolly I'humeur du pays, et me rechargent de dangers et difficultez invincibles." (III, 9, 966) "Je me suis couché mille foys chez moy, imaginant qu'on me trahiroit et assommeroit cette nuict là" (III, 9, 970). Diante do risco iminente de morte, Montaigne se sente pressionado a escapar: "J'eschape” (III, 9, 966).

Outra razão pela qual Montaigne gosta de viajar é o prazer da novidade, da mudança, da variação: "cette humeur avide des choses nouvelles et inconnues ayde bien à nourrir en moy le desir de voyager" (III, 9, 948). A rotina, incessante repetição do mesmo (mesmos cenários, mesmos hábitos, mesmas coisas e pessoas) aborrece-o e entedia-o. A mudança de ares, os novos lugares a conhecer, os diferentes cenários e, principalmente, o espetáculo da diversidade dos costumes despertam-Ihe a curiosidade e o interesse: "je peregrine tres-saoul de nos façons, non pour cercher des Gascons en Sicile (j'en ay assez laissé au logis); je cerche des Grecs plustost, et des Persans: j'acointe ceux-là, je les considere; c'est là où je me preste et où je m'employe" (III, 9, p. 986). Montaigne revela uma excitação quase pueril com a variação dos costumes: "soyent des assietes d'estain, de bois, de terre, bouilly ou rosty, beurre ou huyle de nois ou d'olive, chaut ou froit (...) La diversité des façons d'une nation à autre ne me touche que par le plaisir de la varieté." (III, 9, 985). É um novo mundo que se abre diante dos olhos deste viajante, e o maravilhamento que lhe provoca (contraponto positivo do horror que lhe causa a generalização da perfídia em seu país) tem mesmo algo de infantil: Montaigne é como a criança que se deslumbra diante do novo; que, fascinada pelo desconhecido, tateia-o, investiga-o, experimenta-o. 
Montaigne chega até mesmo a confessar sua imoderação quando se trata de conhecer e experimentar os diferentes costumes: "quand j'ay esté ailleurs qu'en France et que, pour me faire courtoisie, on m'a demandé si je vouloy estre servy à la Françoise, je m'en suis mocqué et me suis tousjours jetté aux tables les plus espesses d'estrangers" (III, 9, 985). Nenhum costume Ihe incomoda; todos Ihe são igualmente agradáveis: "tout m'est un". A novidade causa-lhe tanto prazer que, velho, precisaria moderar um pouco sua curiosidade para que a experimentação do diferente não Ihe causasse mal: "vieillissant, j'accuse cette genereuse faculté, et auroy besoin que la delicatesse et le chois arrestat l'indiscretion de mon appetit et par fois soulageat mon estomac" (III, 9, 985). Enfim, para atestar que só encontra prazer na variação, Montaigne se coloca, com a ajuda de Virgílio e de Horácio, ao lado do patrono dos cirenaicos:

"Aristippus s'aymoit à vivre estrangier partout.

Me si fata meis paterentur ducere vitam

Auspiciis, je choisirois à la passer le cul sur la selle: visere gestiens, Qua parte debacchentur ignes, Qua nebulae pluviique rores."

Se assim é, Montaigne poderia sofrer a mesma acusação de desregramento que Aristipo sofria de seus adversários. Alguém que confessa 
não suportar os sofrimentos morais e ceder diante das pressões da curiosidade e do desejo não mereceria tais epítetos: desregrado, incontinente, fraco? Tanto de um lado quanto de outro, Montaigne confessa ceder. Se nos lembrarmos dos termos em que Aristóteles colocava o problema, poderíamos dizer que o ensaísta não possui nem a virtude da kartería, a fortaleza de ânimo para resistir ao sofrimento, nem a enkráteia - a continência, capacidade de resistir às pressões do desejo. Mas, poderíamos lembrar uma referência teórica ainda mais próxima de Montaigne: o opúsculo De tranquillitate animi, texto no qual Sêneca, em resposta às solicitações de seu atormentado amigo Serennus, formula uma série de prescrições com vistas à tranquilidade da alma. O mal de que Serennus sofre, e para o qual vai buscar remédio junto ao amigo, mestre e médico de almas Sêneca é justamente a inconstância, estado de alma daquele que, mesmo ciente do caminho que deve seguir, cede às pressões do desejo e da dor. No ensaio Da vaidade, Montaigne parece se apresentar como uma espécie de Serennus, lançado de um lado para outro pelo desejo de prazer e pela aversão ao sofrimento. Vale a pena, então, reconstituirmos brevemente os termos nos quais Sêneca apresenta o vício da inconstância no seu opúsculo para podermos medir com mais precisão a proximidade (ou a distância) de Montaigne em relação a esta figura. 


\section{Sêneca e a crítica da inconstância. A indiferença do sábio.}

Sêneca inicia a descrição da inconstância já nas primeiras linhas do opúsculo. Na verdade, a descrição é feita num primeiro momento pelo próprio Serennus, que não sabe exatamente o mal que o acomete e, da mesma forma que um paciente que se dirige ao médico, descreve seus sintomas, à espera de um diagnóstico: "esta fraqueza de alma (...) eu não posso te dizer de uma só vez em que ela consiste, mas apenas te mostrar em detalhe. Eu vou te dizer os sintomas e tu encontrarás um nome para a doença" $(\mathrm{I}, 4)$. Serennus narra os sintomas do mal em três circunstâncias em que o percebe: na sua relação com as riquezas, com a vida política e na escrita. Em cada uma destas ocasiões, o amigo de Sêneca conhece o reto caminho, sabe que preceitos deve seguir e propõe-se firmemente a segui-los; mas, diante das dificuldades e das tentações que encontra pelo caminho, fraqueja, cede - deixa-se levar pelas paixões. Em seguida, arrepende-se e retorna resolutamente, outra vez, para o caminho correto - até que fraqueja novamente. Permanece, assim, dividido entre as paixões e os preceitos, oscilando entre uns e outros, num estado de permanente intranquilidade.

Acompanhemos a descrição dos sintomas do mal. Num primeiro momento, Serennus afirma que sabe que deve levar uma vida modesta, sem luxo. Ele se propõe firmemente a seguir este preceito da escola, a tal ponto que incorpora a frugalidade ao seu próprio caráter: "eu tenho um grande amor pela simplicidade. O que me agrada não são (...) roupas tiradas de um baú perfumado (...) é uma vestimenta interior, que custa pouco e exige pouco para conservar e vestir" (I, 5). No entanto, ao visitar uma casa abastada, a visão do luxo o encanta. As pratarias, os tapetes, o luxo dos móveis, o brilho dos 
ornamentos maravilham-no e seduzem-no: "com todo seu esplendor, o luxo me envolve e atordoa" $(I, 9)$. A tal ponto que, quando retorna ao seu modesto lar, o desgosto e a tristeza começam a se insinuar; a confiança e a tranquilidade que possuía desaparecem: "eu volto para casa não corrompido, mas preocupado. Não caminho mais de maneira tão altiva entre os meus pobres móveis. Uma secreta mordida se insinua em mim" (I, 9). Foi-se embora a certeza que Serennus tinha quanto à veracidade do preceito (de que a vida modesta é a vida melhor). O encantamento com o luxo introduziu a dúvida em seu espírito e pôs fim à sua resolução: "eu me pergunto se aquelas belas coisas não valem mais. Nenhuma delas me transforma; nenhuma delas, no entanto, deixa de me abalar" (I, 9).

O amigo de Sêneca também sabe que deve se dedicar à vida política, ao bem da comunidade - preceito formulado por todos os mestres de sua escola: "eu sigo os conselhos de Zenão, Cleantes e Crisipo. Nenhum deles, sem dúvida, teve acesso aos cargos públicos; nenhum deles, no entanto, deixou de incitar os outros nesta direção" $(I, 10)$. Ele sabe que deve entrar nas disputas pelos cargos, para que possa galgar postos e servir a um conjunto sempre maior de homens: "aos meus amigos, aos meus próximos, aos meus concidadãos e, finalmente, a todos os homens" (I, 10). Convicto da veracidade do preceito da escola (de que a vida dedicada à comunidade é a vida melhor), ele o segue firmemente e entra para a vida pública. No entanto, as dificuldades que encontra pelo caminho, as calúnias e injúrias de que é vítima e as ameaças à sua retidão de caráter ("um incidente que venha a ferir minha alma!") abalam seu firme propósito e fazem-no desistir da carreira política. A vida dedicada às letras, então, passa a lhe aparecer como a vida melhor: 
"como os animais fatigados, meu passos em direção ao abrigo são mais vivazes (...) eu retorno ao meu lazer (...), decido de novo encerrar minha vida entre quatro paredes" (I, 11). Um novo preceito - o do cultivo de si e da preservação do próprio caráter - assume o lugar do anterior. Mais uma vez, Serennus se vê resoluto, empenhado firmemente na realização dos comandos da escola: "que minha alma se fixe em si mesma, que se cultive, que não faça nada que Ihe seja estranho, nada que exija o recurso à opinião do outro; que ela tenha o gosto por uma tranquilidade que ignora as preocupações públicas ou privadas" (I, 12). No entanto, eis que alguma leitura ou a visão de um exemplo de dedicação à comunidade despertam-lhe novamente para o preceito da vida pública ("vem-me então a ideia de correr para o Fórum" - I, 13). Ei-lo novamente empenhado na carreira política, até que uma nova dificuldade se Ihe anteponha outra vez.

Enfim, no registro da escrita, Serennus sabe que deve obedecer ao preceito da simplicidade, da preponderância das coisas (res) sobre as palavras (verba), da clareza e do entendimento da matéria sobre o trabalho com a lexis. Ele conhece o preceito e o segue firmemente quando se dedica à tarefa da escrita: "eu estou de acordo que é preferível encarar as coisas em si mesmas, subordinar-Ihes a linguagem e, de uma maneira geral, dar a palavra às coisas mesmas, a fim de que um estilo sem afetação siga-as aonde elas nos conduzem" $(\mathrm{I}, 14)$. No entanto, se lhe vem à mente uma ideia sublime, uma phantasía que o maravilha e o arrebata ("algum grande pensamento" - I, 15), ele logo abandona o preceito da escrita simples e passa a buscar palavras que correspondam à elevação da matéria ("as palavras vêm [ao meu espírito] 
proporcionadas à sublimidade das ideias" - I, 15). Até que seu arrebatamento cesse e dê lugar, outra vez, ao preceito da escola.

A descrição dos sintomas oferecida por Serennus evidencia o cerne do problema. O amigo de Sêneca padece de uma vontade fraca, que se deixa vencer pela pressão das paixões. Seu problema não é o desconhecimento do bem (do princípio que deve orientar sua conduta), mas sua incapacidade de persistir no caminho certo: "esta fraqueza de uma vontade boa em seu princípio me segue por toda parte" (I, 16). Como ele conhece o bem, propõe-se a buscálo e coloca-se resolutamente na via certa. Mas, diante das pressões das paixões (da aversão às calúnias e à injúria, do amor à riqueza e à glória pela escrita), Serennus fraqueja e se deixa levar. Logo a seguir, sente-se pressionado novamente pela vontade de pôr-se na via certa e de voltar a buscar o bem - até que as paixões outra vez o arrebatam e o levam para a direção oposta. Assim, ele permanece dividido entre as paixões e os preceitos, oscilando entre ambos, num estado de constante perturbação: "[é a] fraqueza de uma alma hesitante entre dois partidos, que não tende com força nem para o bem nem para o mal” $(I, 4)$. Serennus ainda não aderiu plenamente aos comandos da escola; não conseguiu tornar permanente a obediência aos preceitos, a escolha reta; seu caráter ainda não se estabilizou, a ponto de seus propósitos se tornarem inabaláveis: "seu estado de alma", diz-Ihe Sêneca, "é como o das pessoas que se recuperam de uma longa doença (...) seu corpo já está suficientemente curado, mas ainda não se habituou à saúde" (II, 1). Serennus, enfim, ainda não adquiriu a estabilidade característica da constantia: “o que tu procuras (...) é ser inabalável; é este assento estável da alma (...) que eu chamo de tranquilidade" (II, 3). 
Mas, o que significa exatamente dizer que Serennus ainda cede à pressão das paixões? O que são as paixões neste contexto? Todo o problema do amigo de Sêneca reside no fato de que ele ainda cede aos falsos juízos segundo os quais 'as calúnias e injúrias são males' e 'a riqueza e a glória são bens'. As paixões são exatamente os movimentos de alma que seguem estes falsos juízos. Serennus identifica as riquezas e a glória ao bem e passa a buscá-las, esperando encontrar aí contentamento; identifica as calúnias e injúrias ao mal e passa a evitá-las, esperando assim recuperar sua tranquilidade. Ocorre que ele não encontra a satisfação esperada quando alcança o objeto que busca ou quando afasta o motivo da perturbação - e termina se lançando novamente no movimento de busca ou de fuga, que se repõe infinitas vezes: "são pessoas que não obtêm tanto quanto desejam; entregando-se inteiros à esperança, eles são cambiantes e móveis (...) insinuase neles esta agitação de uma alma que não encontra saída (...) que se arrasta entre desejos" (II, 7-8). As coisas exteriores, diz Sêneca, são fins ilusórios, imagens vazias que não trazem satisfação, mas apenas nos levam a retomar o movimento de busca ou de fuga: "não [devemos] compreender tarde demais, para nossa vergonha, a vanidade dos desejos. (...) Não é uma atividade verdadeira que põe em movimento estes agitados; é, como nos loucos, uma imaginação quimérica; pois os próprios loucos não se movem jamais sem alguma esperança; eles são seduzidos por certas aparências, cuja vanidade seu espírito cativo não Ihes desvela" (XII, 1-5). Através da figura de Serennus, e ainda com o auxílio de outros exemplos, Sêneca descreve o movimento sem fim (sem término e sem um alvo verdadeiro) do inconstante; atividade sem sentido e sem propósito, na qual o sujeito se vê arrastado de um lado para o 
outro pelas coisas exteriores, sem jamais encontrar tranquilidade: "é da mesma maneira que aqueles que saem [de casa] apenas para aumentar a multidão são conduzidos aos quatro cantos da cidade pelos motivos mais vãos e mais fúteis"; "eles erram sem desígnio, procurando se ocupar (...) curso irrefletido e vão, como o das formigas que correm ao longo de um arbusto, conduzindo-se ora para cima, ora para baixo e sempre para nada" (XII, 3-6). ${ }^{2}$

As errâncias do viajante aparecem no texto de Sêneca como mais um correlato deste movimento sem sentido e são provocadas pelo mesmo erro. Aquele que viaja em busca de satisfação noutro lugar (em busca de alegrias que não encontra onde está ou para deixar para trás algum sofrimento que não consegue suportar) não a encontrará, pois a insatisfação que o move é um estado de alma que não tem relação com o lugar em que o sujeito está: "para que serve [viajar], se não escapamos de nós mesmos? (...) Devemos sabê-lo: não sofremos pelos defeitos do meio, mas pelos nossos" (II, 14). Daí a necessidade de mudar novamente de ares, reiniciando sempre de novo a busca do contentamento: "assim, adota-se um caminho após o outro, trocamse os espetáculos uns pelos outros" (II, 14). Neste caso, o erro está na associação do lugar com o bem ou o mal:

"Percorremos a costa: um dia no mar, o dia seguinte na terra; por todas as partes manifestamos a mesma instabilidade, o mesmo desgosto do presente. "Vamos, partamos para a Campânia!" Logo, no entanto, queremos descanso dos

\footnotetext{
${ }^{2}$ Os 'homens ocupados' cometem o mesmo tipo de erro de juízo que a figura da esperança: tomam qualquer bobagem, qualquer tarefa vã como um alvo digno, um bem (assim como a figura da esperança toma as coisas exteriores como bens).
} 
refinamentos. "Vejamos então as terras selvagens: embrenhemo-nos nas matas do Bruttium e da Lucânia!" Nestes desertos, entretanto, pomo-nos a desejar algum lugar agradável onde olhos habituados com o luxo possam descansar da longa visão destas paragens ásperas e desumanas. "Rumo a Tarento, seu porto tão celebrado, a suavidade de seu clima no inverno, seu solo suficientemente rico para nutrir as multidões que outrora aí se amontoavam... E agora retomemos o caminho para a capital. Por tempo demais nossos ouvidos foram privados dos aplausos e da algazarra do circo. Eu desejo agora desfrutar deste espetáculo: ver o sangue humano correr"." (II, 13)

A crítica de Sêneca não se limita à vaidade da esperança e da errância. A alma entregue a tais movimentos ainda vê seu mal agravado. Cada expectativa frustrada, cada objeto ou paisagem que não satisfazem tendem a aumentar a carência, aprofundar a insatisfação, ampliar o descontentamento. Sêneca descreve a situação do indivíduo descontente, depois de uma vida dedicada aos negócios, que passa a buscar ("por repugnância de uma vida de esforços sem sucessos!") alguma satisfação no ócio letrado. Tal homem, diz o filósofo, verá seu estado agravado ("e tudo se torna mais grave!"), pois continuará a buscar o contentamento numa coisa exterior (a glória pelas letras), de modo que se verá novamente decepcionado. O mesmo ocorre com aquele que troca uma paisagem pela outra, percorrendo o mundo em busca de satisfação. Ambos, depois de a buscarem por todos os lados, sem encontrá-la, tornam-se presas da melancolia, do taedium vitae: "daí este tédio, este descontentamento de si (...) a tristeza, o langor (...) a inveja que os torna 
furiosos pelos progressos realizados pelos outros (...) a falta de esperança de alcançá-los por si mesmos (...) a irritação contra a sorte, as queixas contra a época" (II, 10). Finalmente, chegam ao seu triste destino: "este estado conduz alguns ao suicídio (...) eles começam a desgostar da vida e do próprio mundo; neles, insinua-se a questão que envenena toda alegria: " - Sempre a mesma coisa! Ah, até quando?'”' (II, 15).

Sêneca ainda fornece uma explicação psicofisiológica ${ }^{3}$ para 0 agravamento da inconstância em função das viagens. Tal vício, diz o filósofo, nasce de um desequilíbrio de uma alma cujas partes estão deslocadas, fora da devida hierarquia; é uma agitação que nasce numa alma que não se encontra perfeitamente coesa. Todo movimento, então, tende a agravar seu estado, assim como aumenta o desequilíbrio de um corpo fora do prumo ("a carga solta no porão afunda o navio" - Ep. 28, 3). A agitação externa agrava a agitação interna; o deslocamento prejudica a alma assim como faz mal a um corpo desconjuntado: "Se alguém quebra a perna ou sofre uma torção, evita andar de carro ou de barco (...) tu crês que os deslocamentos podem fazer bem a uma alma partida e com tantas partes fora do lugar? (Ep. 104, 18). A analogia da doença da alma com a doença do corpo e do agravamento do estado da primeira com o agravamento do estado do segundo não é apenas metafórica, pois, nos quadros da doutrina estóica, a alma é corpórea.

Para uma alma com a doença da inconstância, então, Sêneca recomenda apenas o repouso, o retiro - que ela evite toda agitação, todo estímulo ao seu desequilíbrio: "ela não pode se consolidar senão renunciando antes de tudo à errância. Tu queres disciplinar a alma? Comece por deter o

\footnotetext{
${ }^{3}$ Cf. Epístolas a Lucílio, eps. 28, 69 e 104.
} 
corpo em suas escapadas." (Ep. 69, 1). Ele recomenda que o doente procure buscar contentamento apenas em si mesmo e não mais nas coisas exteriores; que ele aprenda a tomá-las como fins intermediários (skópoı) e não mais como fins em si mesmos (téloı); que ainda as escolha, busque-as, mas sempre visando, para além delas, a retidão da escolha, a virtude; que somente esta seja a razão do seu contentamento: "Não há vício que não ofereça um prêmio: a avareza promete dinheiro; a intemperança, mil prazeres diversos; a ambição, a púrpura e os aplausos (...) Cada vício te solicita pela oferta de um salário. Ora, é necessário viver sem ser pago" (Ep. 69, 4). Assim, o sujeito não mais se decepcionará se perder uma das coisas exteriores (a honra, as riquezas, a saúde, os entes queridos etc.) nem será presa da lógica perversa da esperança e da errância. Ele poderá, então, deixar o repouso (buscar e evitar as coisas exteriores, viajar) sem ser arrastado de um lado para o outro pela esperança, sem errar descontente pelo mundo. Suas viagens não serão mais errâncias, jornadas acompanhadas de expectativa e frustração, mas empresas nas quais ele encontrará alegria e proveito, posto que carrega consigo sua própria tranquilidade (visto que sua satisfação não depende mais do lugar visitado, mas está na virtude, no cumprimento do dever, para o qual a viagem é apenas a ocasião): "Mas também, quando tu tiveres te livrado do mal, todo deslocamento te será agradável. Em vão te exilarão nas extremidades da terra: qualquer que seja o recanto do mundo bárbaro em que te alojarem tu encontrarás (...) um ar hospitaleiro. O importante não é saber onde, mas com qual espírito tu chegas" (Ep. 28, 4). Um exemplo do que seria a viagem estóica (a viagem com vistas ao dever) é dado pelo próprio Sêneca na Epístola 104, na qual ele diz que, ameaçado pela malária em Roma, viaja para Nomentum não 
por medo da morte, mas para assegurar, através da própria sobrevivência, a manutenção da esposa: "Paulina é a causa de eu ter tomado minha saúde em consideração (...) como eu sei que a sua existência depende da minha, eu começo, para poupá-la, a poupar a mim mesmo" (Ep. 104, 2).

\section{Vaidade do modelo do sábio. As paixões como realidade incontornável.}

E quanto a Montaigne? O ensaísta sabe que o seu gosto pelas viagens é um bom motivo para que seja acusado de inconstância: "Je sçay bien qu'à le prendre à la lettre, ce plaisir de voyager porte tesmoignage d'inquietude et d'irresolution." (III, 9, 988) Como ele responde à crítica? Antes de tudo, confessando seu gosto pela variedade, pela mudança: "Ouy, je le confesse, je ne vois rien, seulement en songe et par souhait, où je me puisse tenir; la seule varieté me paye, et la possession de la diversité, au moins si aucune chose me paye." (idem). Ao longo de todo o ensaio, é assim que Montaigne parece se apresentar: como uma figura da inconstância. Ele é movido pelo desejo de prazer e pela aversão ao sofrimento, atribui valor às coisas exteriores e deixase mover por elas: "Parmy les conditions humaines, cette-cy est assez commune: de nous plaire plus des choses estrangeres que des nostres et d'aymer le remuement et le changement. (...) J'en tiens ma part." (III, 9, 948)

Montaigne dá voz a seus críticos, reproduzindo a censura que poderiam fazer ao seu comportamento: "Dequoy avez-vous faute? Vostre maison est elle pas en bel air et sain, suffisamment fournie, et capable plus que suffisamment? (...) Vostre famille n'en laisse elle pas en reiglement plus au dessoubs d'elle qu'elle n'en a au dessus, en eminence?" (III, 9, 987) Em termos 
idênticos aos de Sêneca no De tranquillitate animi, ele aponta a ilusão de quem pensa que vai encontrar contentamento buscando um novo objeto ou mudando de lugar: "Où cuidez vous pouvoir estre sans empeschement et sans destourbier? (...) Voyez donc qu'il n'y a que vous qui vous empeschez, et vous vous suyverez par tout, et vous plainderez par tout" (idem). Enfim, ele expõe o cerne da crítica: não há satisfação possível para 0 desejo; não há preenchimento possível para a carência; nenhum objeto ou lugar (nenhuma das coisas exteriores) é capaz de trazer contentamento. A única solução possível é deixar de tomar os objetos exteriores como fim último e passar a buscar contentamento apenas na virtude: "Reformez vous seulement, car en cela vous pouvez tout (...) Contentez vous du vostre, c'est à dire de la raison." (idem).

Com ironia e sutileza, Montaigne responde aos críticos que compreende a advertência ("Je voy la raison de cet advertissement, et la voy tres-bien" - III, 9,988 ) e concorda que o preceito que lhe propõem (que se contente com a virtude) "é um preceito salutar". Mas, acrescenta que lhe é impossível realizálo. Afinal, seus críticos the propõem nada mais nada menos do que o paradigma do sábio: "Cette resolution est outre la sagesse: c'est son ouvrage et sa production" (idem). Esta firmeza de ânimo, acrescenta o ensaísta, não é fácil nem mesmo para os mais sábios; que dizer então para ele, um homem medíocre? ("L'execution (...) n'en est non plus [facile] aux plus sages qu'en moy. (...) je ne suis qu'homme de la basse forme." - idem) Seus críticos exigem que ele adote a conduta de um modelo infinitamente distante, pedem-lhe uma espécie de conversão miraculosa do vício para a virtude perfeita: "on auroit plustost faict, et plus pertinemment, de me dire en un mot: Soyez sage. (...) 
Ainsi faict le medecin qui va criaillant apres un pauvre malade languissant, qu'il se resjouysse; il luy conseilleroit un peu moins ineptement s'il luy disoit: Soyez sain." (idem) Enfim, pedem-Ihe que realize um projeto impossível - que deixe de tomar como alvo último de suas ações toda e qualquer outra coisa que não a razão: "C'est une parolle populaire, mais elle a une terrible estandue. Que ne comprend elle?" (idem).

Não se trata apenas de recusar um paradigma distante. Trata-se de repelir uma prescrição contrária às inclinações que Montaigne percebe serem as mais comuns e persistentes nos homens ${ }^{4}$ : "La vie est un mouvement materiel et corporel, action imparfaicte de sa propre essence, et desreglée" (III, 9, 988). Montaigne olha em torno de si e vê que todos os homens são movidos pelo desejo do prazer e pela aversão à dor, que buscam e fogem das coisas exteriores, tomando-as como fins últimos. Examina-se e percebe as mesmas tendências. Ele não pode acatar um preceito que vá de encontro e violente este

\footnotetext{
${ }^{4} \mathrm{O}$ texto tensiona explicitamente o paradigma proposto pelos estóicos e certa concepção do homem. Montaigne acusa a vanidade do preceito à luz da impossibilidade dos homens realizarem-no (é um cume sobre o qual "nenhum ser humano pode se sentar"). Outro termo ao qual ele recorre é o "nós" em que ele se inclui e que designa a coletividade humana ("ces regles qui excedent nostre usage e nostre force"). Entendemos que estas noções não implicam necessariamente nenhuma referência à natureza ou a uma universalidade. Quando Montaigne fala dos 'homens' ou deste 'nós' em que se inclui (e que frequentemente aparece como 'nós, homens fracos' - cf. próximo capítulo), pensamos tratar-se de uma noção obtida por experiência (que permanece, portanto, como uma generalidade frouxa, aberta à refutação por experiências futuras), não uma universalidade formulada teoricamente. Da mesma forma, entendemos que Montaigne se refere às inclinações humanas como um fenômeno observável, sem poder dizer se ele exprime uma natureza oculta.
} 
comportamento espontâneo. Passa a propor, então, a aceitação das nossas tendências: "je m'emploie à la servir [à vida] selon elle" (idem).

Na medida em que contraria as inclinações espontâneas da maioria dos homens, o preceito estóico é vão, inútil: "A quoy faire ces poinctes eslevées de la philosophie sur lesquelles aucun estre humain ne se peut rassoir, et ces regles qui excedent nostre usage et nostre force?" (III, 9, 989). Assim, Montaigne volta a acusação de seus críticos contra eles próprios: "Il y a de la vanité, dictes vous, en cet amusement. Mais où non? Et ces beaux preceptes sont vanité, et vanité toute la sagesse" (III, 9, 988). Com uma pincelada satírica, afirma que sequer o proponente deste preceito acredita poder segui-lo; pior: ele nem mesmo o desejaria: "Je voy souvent qu'on nous propose des images de vie, lesquelles ny le proposant ny les auditeurs n'ont aucune esperance de suyvre ny, qui plus est, envie." (III, 9, 989). Enfim, os discursos que o propõem são belas peças retóricas que conseguem nos comover ("I'invention, l'eloquence, la pertinence frape incontinent vostre esprit et vous esmeut"), mas não nos transformar ("il n'y a rien qui chatouille ou poigne vostre conscience").

O rigor excessivo do preceito leva necessariamente à desobediência e à hipocrisia. Forçados a seguir uma regra impossível de ser posta em prática, os homens terminam fingindo que a obedecem, enquanto pressionam os outros para que a sigam:

“De ce mesme papier où il vient d'escrire l'arrest de condemnation contre un adultere, le juge en desrobe un lopin pour en faire un poulet à la femme de son compaignon. Celle à qui vous viendrez de vous frotter illicitement, criera plus asprement tantost, en vostre presence mesme, à l'encontre 
d'une pareille faute de sa compaigne que ne feroit Porcie. Et tel condamne des hommes à mourir pour des crimes qu'il n'estime point fautes. J'ay veu en ma jeunesse un galant homme presenter d'une main au peuple des vers excellens et en beauté et en desbordement, et de l'autre main en mesme instant la plus quereleuse reformation theologienne de quoy le monde se soit desjeuné il y a long temps. Les hommes vont ainsin. On laisse les loix et preceptes suivre leur voie, nous en tenons une autre; non par desreiglement de meurs seulement, mais par opinion souvent et par jugement contraire." (III, 9, 989 - grifos nossos)

O rigor excessivo do preceito leva à desobediência. Em seguida, ele acusa e condena aqueles que ele próprio impeliu ao desvio. De modo que o preceito não é apenas vão como ainda injusto: "[II] semble la visée injuste, à laquelle on ne peut atteindre. (...) L'homme s'ordonne à soy mesme d'estre necessairement en faute. (...) A qui prescript il ce qu'il s'attend que personne ne face? Luy est il injuste de ne faire point ce qu'il luy est impossible de faire? Les loix qui nous condamnent à ne pouvoir pas nous accusent elles mesmes de ne pouvoir pas." (III, 9, 990-991)

Montaigne, enfim, recusa a solução estóica para o problema das paixões, a saber, a imitação da perfeita indiferença do sábio diante dos bens e dos males de opinião (da conduta desta figura que só busca, em última instância, a virtude), pois sabe que esses bens e esses males nos afetam incontornavelmente, despertando impulsos de desejo e de aversão e arrastando alguns até os extremos da paixão (da ambição, da cólera, da tristeza, do medo etc.). A maioria de nós experimenta alguma perturbação 
diante de alguma destas coisas; e não pode evitar experimentá-la. É o que percebe Montaigne quando analisa a si mesmo e os homens à sua volta (e o que o leva a entender que a indiferença do sábio é inatingível para a maioria dos homens). Por mais que tente conter ou moderar seus afetos e evitar perturbar-se, a mera visão de certas coisas (seja efetivamente presentes, seja manifestadas na forma de representações), abala-o, compromete sua serenidade; enfim, desperta nele movimentos de alma que podem apenas incomodar ou provocar grandes sofrimentos:

"Je ne suis pas philosophe: les maux me foullent selon qu'ils poisent; et poisent selon la forme comme selon la matiere, et souvent plus. J'en ay plus de cognoissance que le vulgaire; si j'ay plus de patience. En fin, s'ils ne me blessent, ils m'offencent. C'est chose tendre que la vie et aysée à troubler. Depuis que j'ay le visage tourné vers le chagrin (nemo enim resistit sibi cum coeperit impelli), pour sotte cause qui m'y aye porté, j'irrite l'humeur de ce costé là, qui se nourrit après et s'exaspere de son propre branle; attirant et emmoncellant une matiere sur autre, de quoy se paistre." (III, 9, p. 950)

A paixão é um fato a ser reconhecido e aceito, não algo que possa ser suprimido. Diante da mera imagem de objetos que lhe dão prazer, Montaigne experimenta as pressões do desejo; diante das coisas que lhe causam sofrimento, sente-se pressionado por impulsos de aversão. Em Da vaidade, Montaigne aprende que tais afetos são uma realidade incontornável; que deve aceitá-los. Mas isto lhe coloca um problema, pois aceitar as paixões é correr o 
risco da servidão. Este risco, como veremos ainda agora, o autor não aceita. Se Da vaidade é o ensaio em que Montaigne diz ceder às pressões do desejo e da aversão, também é nele que o ensaísta demonstra todo seu amor à liberdade, todo seu esforço para manter-se independente das coisas exteriores. Mas se é assim, teremos então de nos perguntar se o projeto de liberdade do autor termina por fracassar, ou se ele encontra, a despeito das pressões dos afetos (ou mesmo levando-os em consideração), alguma nova expressão da liberdade, que finalmente seja distinta da perfeita autarquia almejada pelos estóicos.

\section{O risco da servidão. Montaigne e a defesa da liberdade.}

Aceitar o fato incontornável dos impulsos do desejo e da aversão, no entanto, implica em assumir o risco da servidão. Toda uma longa tradição da filosofia moral já assinalara este ponto, e uma das principais escolas que se dedicaram a fazê-lo foi justamente a dos estóicos. Leitor assíduo de Sêneca, Montaigne conhece os inúmeros textos em que o filósofo romano destaca e acusa a servidão do homem que se deixa levar pelo desejo. A crítica da inconstância tem como centro exatamente este ponto. Embora recuse a constantia como modelo de conduta (a virtude como único fim das ações), Montaigne não aceita a servidão. Ele ama demais a liberdade para que se permita escravizar-se às 'coisas exteriores'.

Numa longa passagem bem no meio do ensaio, o autor expõe todo o seu amor pela liberdade, narrando para o leitor os expedientes de que lança mão para se manter livre. Ele começa lamentando as circunstâncias da guerra e a situação de servidão que elas the impuseram. Diz que sempre fizera de 
tudo para se manter livre, mas se viu forçado pelas vicissitudes à servidão. Isto porque seus vizinhos e parentes protestantes, para retribuir o respeito que 0 católico Montaigne sempre Ihes dedicara, poupam-Ihe a vida e o protegem num momento de recrudescimento da guerra. Ocorre que, assim, colocam-no na posição de devedor, fazendo-o assumir a maior de todas as dívidas de gratidão - a da própria sobrevivência:

"Comme les choses sont, je vis plus qu'à demy de la faveur d'autruy, qui est une rude obligation. Je ne veux debvoir ma seureté, ny à la bonté et benignité des grands, qui s'aggréent de ma legalité et liberté, ny à la facilité des meurs de mes predecesseurs et miennes. Car quoy, si j'estois autre? Si mes deportemens et la franchise de ma conversation obligent mes voisins ou la parenté, c'est cruauté qu'ils s'en puissent acquiter en me laissant vivre, et qu'ils puissent dire: Nous luy condonnons la libre continuation du service divin en la chapelle de sa maison, toutes les esglises d'autour estant par nous desertées et ruinées, et luy condonnons l'usage de ses biens, et sa vie, comme il conserve nos femmes et nos beufs au besoing." (III, 9, 966)

Fazendo eco às passagens dos clássicos sobre a virtude da liberalidade, Montaigne aponta a beleza do gesto largo, da doação, sinal de superioridade e de liberdade; da mesma forma, aponta a feiúra da dívida, da aceitação de presentes e favores, indício de inferioridade e de servidão: "Comme le donner est qualité ambitieuse et de prerogative, aussi est l'accepter qualité de summission" (III, 9, 969). Por meio do favor concedido, o benfeitor dá uma 
demonstração de seu próprio valor, coloca-se em posição de superioridade em relação ao beneficiado. O favor obriga o favorecido, coloca-o em dívida de gratidão em relação ao que o favoreceu. No momento em que aceita o benefício, o beneficiado perde algo de sua própria liberdade. Por meio da dívida de gratidão, ele se submete ao outro.

Para um nobre, homem que pretende manter-se livre e dar mostras de seu próprio valor, a dívida de gratidão é insuportável: "Je fuis à me submettre à toute sorte d'obligation, mais sur tout à celle qui m'attache par devoir d'honneur. Je ne trouve rien si cher que ce qui m'est donné et ce pourquoy ma volonté demeure hypothequée par tiltre de gratitude" (III, 9, 966). Recorrendo a uma imagem, Montaigne opõe as relações de comércio às da clientela, dizendo preferir comprar os serviços a recebê-los como favor, posto que no primeiro caso paga-os com dinheiro, enquanto no segundo com sua própria liberdade: "[je] reçois plus volontiers les offices qui sont à vendre. Je croy bien: pour ceuxcy je ne donne que de l'argent; pour les autres je me donne moy-mesme" (idem). A dívida de gratidão o incomoda particularmente porque sua carga simbólica ultrapassa qualquer quitação. A dívida pode ser paga, mas o gesto liberal (que não espera retribuição, mas apenas exaltar o próprio benfeitor) e a posição subalterna do beneficiado nunca se apagam: "Ceux que je voy si familierement employer tout chacun et s'y engager, ne le fairoient pas s'ils poisoient autant que doit poiser à un sage home l'engageure d'une obligation: elle se paye à l'adventure quelquefois, mais elle ne se dissout jamais" (III, 9, 969).

A dívida de gratidão instaura uma relação de heteronomia. Este é o ponto que tanto perturba Montaigne: que o outro the obrigue por meio do 
benefício; que o dever the seja imposto de fora. Para escapar desta relação, ele põe para si mesmo o dever e procura cumpri-lo rigorosamente: "Je suis delicat à l'observation de mes promesses jusques à la superstition (...) A celles qui sont de nul poids je donne poids de la jalousie de ma regle: elle me gehenne et charge de son propre interest" (III, 9, 966). O rigor de Montaigne para consigo mesmo é uma forma de escapar da heteronomia. Na medida em que põe para si mesmo um dever mais estrito do que o que poderiam the cobrar, furta-se às imposições vindas de fora; a autonomia ${ }^{5}$ é a saída para escapar do jugo do outro: "La condemnation que je faits de moy est plus vifve et plus roide que n'est celle des juges, qui ne me prennent que par le visage de l'obligation commune, l'estreinte de ma conscience plus serrée et plus severe. (...) Je suy lachement les debvoirs ausquels on m'entraineroit si je n'y allois." (III, 9, 967)

Outras estratégias são utilizadas por Montaigne com vistas a preservar a própria liberdade. Assim como é rigoroso no cumprimento dos deveres que põe para si mesmo, é displicente na observância dos que lhe são impostos pelo outro: "Où la necessité me tire, j'ayme à lacher la volonté. Quod me jus cogit, vix voluntate impetrent". É como se um certo grau de desobediência aos deveres impostos fosse mais digno (fosse um indício maior de liberdade) do que a obediência estrita: "quia quicquid imperio cogitur, exigenti magis quam

\footnotetext{
${ }^{5}$ Evidentemente, não se trata de uma autonomia de tipo kantiano. Montaigne não espera chegar, pelo exercício da razão, a leis morais universais. Trata-se, segundo cremos, da autonomia de quem reconhece e legitima os costumes de seu país e os valores legados por uma longa tradição da Filosofia Moral ocidental; que os incorpora ao longo de seu processo de formação e os faz seus, seguindo-os voluntariamente. É neste sentido que se pode falar em autonomia e em recusa da heteronomia em Montaigne.
} 
praestanti acceptum refertur." A desobediência aos deveres impostos, porém, tem limites bastante claros para o autor: "J'en sçay qui suyvent cet air jusques à l'injustice: donnent plustost qu'ils ne rendent, prestent plustost qu'ils ne payent, font plus escharsement bien à celuy à qui ils en sont tenus. Je ne vois pas là, mais je touche contre."

Outra estratégia para fugir da obrigação ao outro é usar as ofensas que recebe dos benfeitores para quitar sua dívida, como se não responder a tais ofensas fosse um favor que ele prestasse de volta: "J'ayme tant à me descharger et desobliger que j'ay par fois compté à profit les ingratitudes, offences et indignitez que j'avois receu de ceux à qui, ou par nature ou par accident, j'avois quelque devoir d'amitié, prenant cette occasion de leur faute à autant d'acquit et descharge de ma debte."

Enfim, Montaigne esforça-se para não precisar de nada nem de ninguém. Numa verdadeira profissão de fé de autarquia que lembra certas passagens de Sêneca, ele afirma que tenta reduzir suas necessidades e evitar apegar-se às 'coisas exteriores', que sabe serem contingentes. Ele sabe que sua própria sobrevivência está à mercê das variações da Fortuna e cultiva seu próprio ânimo, preparando-se para as perdas:

"J'essaye à n'avoir expres besoing de nul. In me omnis spes est mihi. (...) II fait bien piteux et hazardeux despendre d'un autre. Nous mesmes, qui est la plus juste adresse et la plus seure, ne nous sommes pas assez asseurez. Je n'ay rien mien que moy et si en est la possession en partie manque et empruntée. Je me cultive et en courage, qui est le plus fort, et encores en 
fortune, pour y trouver de quoy me satisfaire quand ailleurs tout m'abandonneroit." (III, 9, 968)

Até então, todos os seus esforços teriam sido bem sucedidos, todo o conhecimento que empregou da 'ciência dos benefícios' ("qui est une subtile science et de grand usage") teria lhe auxiliado a assegurar a própria liberdade. Montaigne chega a se apresentar como o homem mais livre de sua época, o menos obrigado pelas relações de clientela: "Apres tout (...) je ne vois personne plus libre et moins endebté que je suis jusques à cette heure. Ce que je doibts, je le doibts aux obligations communes et naturelles. II n'en est point qui soit plus nettement quitte d'ailleurs" (III, 9, 968). Ele se felicita por isso, demonstra gratidão pela boa fortuna e desejaria ter podido continuar assim:

“O combien je suis tenu à Dieu de ce qu'il luy a pleu que j'aye receu immediatement de sa grace tout ce que j'ay, qu'il a retenu particulierement à soy toute ma debte! Combien je supplie instamment sa saincte misericorde que jamais je ne doive un essentiel grammercy à personne! Bienheureuse franchise, qui m'a conduit si loing. Qu'elle acheve" (III, 9, 968).

No entanto, por mais que tenha se esforçado em contrário, as circunstâncias o obrigaram a se endividar. Manter-se livre, depender apenas de si mesmo, "é coisa que todos podem, porém mais facilmente aqueles que já têm as necessidades básicas satisfeitas", diz o ensaísta. Pois bem. Eis que as circunstâncias da guerra puseram em risco a mais básica de suas necessidades: sua própria preservação. Eis que, para salvar sua vida, ele foi 
obrigado a rifar a própria liberdade. Montaigne lamenta profundamente a situação: "Cruel garrotage à qui ayme affranchir les coudées de sa liberté en tous sens!" (III, 9, 969) Sobretudo, lamenta ter sido forçado pelas circunstâncias a contrair uma dívida tão grande, praticamente insaldável: "Je veux donc dire que, s'il faut ainsi debvoir quelque chose, ce doibt estre à plus legitime titre que celuy dequoy je parle, auquel la loy de cette miserable guerre m'engage, et non d'un si gros debte comme celuy de ma totale conservation: il m'accable" (III, 9, 970).

\section{Senso de conveniência e concessão oportuna às paixões.}

Os esforços de Montaigne para se manter independente das 'coisas exteriores' fracassaram. Diante do risco da própria morte, o autor cede e aceita a proteção de seus vizinhos. Ele não consegue se manter firme o suficiente e levar a liberdade até os extremos do sacrifício; ele ama demais a vida para isso (não consegue se manter indiferente a ela; enfim, cede às pressões da paixão). Aliás, todo o ensaio Da vaidade é pautado pelas concessões de Montaigne às paixões. Ele não pode evitar encolerizar-se quando se depara com a inépcia de um criado, ou com os furtos de outro ("à toute heure je (...) heurte chez moy en quelque rencontre qui me desplaise" - III, 9, 950), nem contornar a melancolia

que o acomete quando lhe vem à mente a perspectiva da dissolução do estado francês, dilacerado pela perfídia ("l'extreme de noz craintes!"), nem deixar de sentir medo quando analisa as perspectivas da velhice ou quando percebe que, nas circunstâncias da guerra, sua morte pode estar ainda mais próxima ("imaginant qu'on me trahiroit et assommeroit cette nuict là" - III, 9, p. 970). E não consegue fazer frente às pressões destas paixões (nem suportá-las, nem 
moderá-las). Atormentado por elas, Montaigne pode apenas fugir, afastar-se da visão das coisas que the perturbam, buscar um pouco de alegria e de prazer alhures - enfim, deixar-se levar pelos impulsos do desejo e da aversão. Estaríamos, então, diante de uma figura da servidão, de um homem que aceita ser subjugado por seus afetos? Uma leitura superficial do ensaio parece apontar nesta direção. Mas o leitor diligente percebe que, a cada vez que Montaigne cede às paixões que 0 acometem, a cada vez que se deixa levar pelas pressões do desejo e da aversão e lança-se em viagem, ele sabe exatamente o que está fazendo, tem total controle sobre suas ações e não deixa de atender, em nenhum momento, às exigências dos deveres que se the impõem; ao contrário, ele discerne as ocasiões em que ceder aos afetos permite-Ihe cumprir seus deveres ainda mais rigorosamente. Enfim, uma leitura atenta de $\mathrm{Da}$ vaidade mostra-nos que Montaigne possui um senso de conveniência que lhe permite discernir em que circunstâncias é oportuno ceder às paixões $-\mathrm{e}$ viajar.

De fato, se acompanhamos de perto cada uma das alegações que o autor dá para deixar os limites de seu castelo e de seu país, descobrimos uma atenção cuidadosa às exigências mais rigorosas da administração da casa, da vida política e da relação com a própria morte. Sua aparente negligência em relação à própria casa (a falta de vigilância sobre os pequenos furtos praticados pelos servos, as separações periódicas da esposa e da filha por causa das viagens) visa, ao mesmo tempo que a tranquilidade do autor, a renovação e o estreitamento dos laços de afeição e de confiança entre os familiares (a coesão da casa); sua saída da França no momento da guerra civil é semelhante à atitude do médico que observa o corpo doente à distância e 
aguarda o arrefecimento da crise, ciente de que uma intervenção que visasse mudar o estado das coisas no momento de turbulência poderia agravar ainda mais o mal e conduzir o corpo doente à morte; enfim, Montaigne busca o prazer da viagem para temperar as tristezas que acompanham a velhice - a falta de desejo, a doença e a perspectiva da própria morte. Sobretudo, diante do absurdo da guerra e da perspectiva da própria aniquilação, o autor encontra nas pequenas alegrias e nos prazeres mais banais (mais vãos) uma centelha de sentido.

Vale a pena, então, retornar aos movimentos de fuga da casa e do país em busca deste senso de conveniência montaigniano. Após percorrermos cada uma das etapas desse trajeto poderemos nos perguntar novamente se as concessões muito oportunas que Montaigne faz às próprias paixões não revelariam uma nova figura da liberdade, muito distinta da perfeita autarquia e da impassibilidade almejada pelos estóicos.

\subsection{Conveniência na administração da casa. Afeição, confiança e justiça.}

No longo trecho que dedica à descrição dos aborrecimentos que lhe provocam as tarefas da administração da casa, Montaigne parece se mostrar negligente em relação à sua função de administrador, provocando no leitor a impressão de um descuido que poderia ter como consequência o colapso da casa. Particularmente, chama a atenção a relação que o ensaísta mantém com suas finanças, 'considerando-as de longe', 'evitando todo controle miúdo'. A perspectiva de colapso financeiro da família, aliás, já era antecipada por seu 
pai: "celuy qui me laissa ma maison en charge prognostiquoit que je la deusse ruyner, regardant à mon humeur si peu casaniere" (III, 9, p. 998). Com suas viagens, Montaigne parece igualmente negligente em relação à esposa, e é acusado por isso: "aucuns se plaignent dequoy je me suis agreé à continuer cet exercice, marié" (III, 9, p. 974). Em relação às duas tarefas - a administração dos bens e das relações conjugais - salta aos olhos apenas o desinteresse do autor. Mas isto apenas para uma leitura superficial do texto.

Montaigne certamente tinha conhecimento da longa tradição dos lógoi oikonomikói, verdadeiros manuais que prescreviam regras para a boa administração do oîkos (o conjunto do que a família possui: a oikía ou a casa propriamente dita, os bens, os títulos, assim como os valores morais e as tradições herdadas), tendo sido responsável pela publicação dos Econômicos de Xenofonte, traduzidos por La Boétie. O que prescreviam esses escritos? Eles apontavam as qualidades do bom chefe do oîkos, estabeleciam a divisão de tarefas entre o esposo e a esposa, forneciam conselhos a respeito da administração dos bens (como gerir os recursos financeiros da casa, como tornar as terras produtivas) e assinalavam os deveres que o chefe de família deveria cumprir para com seus servos e familiares - vivos e antepassados. Cada um desses tópicos é abordado por Montaigne em Da vaidade. Por exemplo, a necessidade de preservação da memória dos antepassados: "Le soing des morts nous est en recommendation. (...) mon pere (...) je ne laisse pas d'embrasser et practiquer la memoire" (III, 9, p. 996). Ou, ainda, a necessidade de prover o sustento dos servos (o dever de evitar "l'indigence et oppression de vostre peuple" - III, 9, p. 948), de assegurar o futuro dos filhos (“La Fortune (...) m'a osté le besoing de multiplier en richesses pour pourvoir à 
la multitude de mes heritiers. Pour un, s'il n'a assez de ce de quoy j'ay eu si plantureusement assez, à son dam" - III, 9, p. 949), de oferecer uma boa recepção para os hóspedes ("[je] treuve laid qu'on entretienne ses hostes du traictement qu'on leur faict" - III, 9, p. 954) etc. Enfim, se Montaigne é displicente em relação às tarefas da administração da casa, não se pode dizer que as desconhecia. Mas, seria ele realmente negligente no governo do oîkos? Ou, ao contrário, tomando a distância que toma na execução da atividade, não procuraria justamente atender às mais profundas exigências da mesma?

Sem dúvida, seu relativo distanciamento é cuidadosamente calculado e rigorosamente conveniente. Isto porque, mais do que simplesmente multiplicar riquezas e assegurar o sustento material da família e o futuro dos filhos, mais do que somente cumprir com seus deveres sexuais para com a esposa, a tarefa do administrador do oîkos é moral - pois, dentre todos os bens da casa, os maiores são seus valores. Assim, quando diz que não pretende enriquecer, mas apenas, "par retranchement de despence", prevenir a pobreza, Montaigne não faz pouco caso do sustento futuro dos filhos. Tendo apenas uma única, sabe possuir o suficiente para prover suas necessidades quando não estiver mais presente - e, se não se esforça por the deixar ainda mais, é porque procura prover-Ihe este bem maior, a moderação: "pour un [heritier], s'il n'a assez de ce de quoy j'ay eu si plantureusement assez, à son dam; son imprudence ne merite pas que je luy en desire davantage" (III, 9, p. 949). Da mesma forma, quando viaja, Montaigne não negligencia a administração da casa, mas a deixa sob os cuidados da esposa, reivindicando a divisão de tarefas prescrita pelos lógoi oikonomikói: "Je vois avec despit en plusieurs mesnages monsieur revenir maussade et tout marmiteux du tracas des affaires, 
environ midy, que madame est encore apres à se coiffer et atiffer en son cabinet" (III, 9, p. 975). Assim como o cidadão deve zelar pela promoção da justiça na pólis, o administrador deve promovê-la no oîkos.

Quanto aos deveres do marido para com a esposa, Montaigne tem obrigações sexuais que, supostamente, seriam prejudicadas por suas viagens frequentes. Aqui, no entanto, as viagens também tem a função de promover a moderação: "Et ne doibt une femme avoir les yeux si gourmandement fichez sur le devant de son mari qu'elle n'en puisse voir le derriere où besoing est" (III, 9, p. 976). Mas não se trata de um moralismo espiritualista, e sim da busca de uma moderação que só tem por efeito ampliar o prazer, ao afastar o risco da insensibilização decorrente do excesso:

"Quant aux devoirs de l'amitié maritale qu'on pense estre interessez par cette absence, je ne le crois pas. Au rebours, c'est une intelligence qui se refroidit volontiers par une trop continuelle assistance, et que l'assiduité blesse. (...) Et chacun sent par experience que la continuation de se voir ne peut representer le plaisir que l'on sent à se desprendre et reprendre à secousses. Ces interruptions me remplissent d'une amour recente envers les miens et me redonnent l'usage de ma maison plus doux" (III, 9, p. 975)

As viagens tem por efeito estreitar os laços entre os familiares, laços que se afrouxam com a 'presença demasiadamente contínua'. Acima de tudo, a tarefa do administrador do oîkos é zelar por esses laços, e é por isso que Montaigne prefere confiar nos seus servos a controlar de maneira miúda os 
gastos da casa, procurando evitar possíveis furtos. Ele espera conquistar a lealdade dos que estão à sua volta, por meio de provas de confiança: "Qui a la garde de ma bourse en voyage, il l'a pure et sans contre-role: aussi bien me tromperoit il en contant; et, si ce n'est un diable, je l'oblige à bien faire par une si abandonnée confiance" (III, 9, p. 953). Buscando a prevalência da fides nas relações familiares, Montaigne procura assegurar a coesão da casa, estreitando os vínculos entre suas partes. E lamenta quando não encontra a lealdade daqueles que lhe são mais próximos: "Mais quoy? nous vivons en un monde où la loyauté des propres enfans est inconnue" (III, 9, p. 953).

A aparente displicência de Montaigne na administração das finanças tem ainda último objetivo. Lembremo-nos que os lógoi oikonomikói também prescreviam as qualidades do bom chefe do oîkos, que não se limitavam a habilidades administrativas. Para promover a virtude na casa, o chefe de família também deveria buscá-la. Assim, a distância de Montaigne no trato com as finanças, seu relativo descuido no controle dos gastos e receitas, tem por finalidade evitar um risco sempre presente no escrúpulo excessivo em relação ao dinheiro: "O le vilein et sot estude d'estudier son argent, se plaire à le manier, poiser et reconter. C'est par là que l'avarice faict ses aproches" (III, 9, 953). Mesmo uma "liberalité trop ordonnée et artificielle", considera Montaigne, revela a cupidez. A virtude da liberalidade, enfim, exige um pouco de descuido na relação com as finanças - sinal, justamente, de um certo desapego em relação ao dinheiro, que, em si mesmo, diz Montaigne, é indiferente: "La garde ou l'emploite sont de soy choses indifferentes, et ne prennent couleur de bien ou de mal que selon l'application de nostre volonté" (III, 9, p. 955). 
Assim, percebemos que a aparente negligência do ensaísta na administração da casa é a outra face de uma profunda diligência no cumprimento da principal tarefa da economia: a promoção da virtude e do estreitamento dos laços entre os familiares - dos valores que constituem os maiores bens a serem preservados e reforçados pelo administrador do oîkos. Mas, esta negligência diligente - já explorada por outros comentadores do pensamento montaigneano a respeito dos procedimentos de escrita do gênero ensaio - não se aplica apenas à condução dos assuntos da casa: Montaigne também a faz valer, como veremos na sequência, na relação que mantém com os assuntos públicos.

\subsection{A conveniência na política. Crítica das iniciativas reformistas e da perfídia. Cosmopolitismo sem universalismo.}

Quando Montaigne escreve o ensaio Da vaidade, pelos idos de 1586, mais de cinquenta anos haviam se passado desde o início das perseguições aos protestantes na França, e mais de vinte tinham transcorrido desde a deflagração da luta armada (da guerra propriamente dita) entre os exércitos católicos e as milícias huguenotes. Dos oito períodos de guerra que marcariam os anos de 1562 a 1598, sete já haviam se passado, dezenas de batalhas haviam ocorrido por todo o país, e o saldo da guerra (que só haveria de terminar doze anos depois) já era pavoroso: milhares de franceses haviam matado e morrido em nome de sua fé. Em 1572, o episódio mais tenebroso de todas as guerras de religião, a Noite de São Bartolomeu, mostrou até que ponto a Coroa seria capaz de chegar para tentar assegurar a unidade do 
Reino. Pressionado pelo clamor de vingança da multidão protestante que havia chegado em Paris para assistir às festividades do casamento de Henrique de Navarra com Marguerite de Valois e terminara presenciando a tentativa de assassinato de um de seus líderes, Coligny, o rei Carlos IX decide sufocar a rebelião iminente mandando matar os líderes protestantes então reunidos na cidade, o que daria início a sucessivos massacres de huguenotes em diversas cidades francesas nos dias subsequentes. Um banho de sangue inunda algumas regiões do país. Diante da violência dos conflitos que se estenderiam até os dias em que escreve o ensaio Da vaidade (sobretudo, diante do horror da guerra civil, na qual homens até então ligados por laços de origem, cultura e língua passavam a matar uns aos outros), Montaigne não pode deixar de expressar todo o assombro e repulsa que experimenta. Na falta de palavras à altura, ele pede auxílio ao poeta:

"Ai de nós! Nossas cicatrizes, nossos crimes, nossas guerras fratricidas cobrem-nos de vergonha! Filhos de um século bárbaro, ante qual atrocidade recuamos? Até onde não levamos nossos atentados? Algum dia o temor aos deuses reteve a mão de nossa juventude? Quais altares ela poupou?" 6

\footnotetext{
${ }^{6}$ A passagem reproduz, em prosa, os versos de Horácio (Odes, XXXV, 33) citados em latim por Montaigne: "Eheu cicatricum et sceleris pudet / Fratrumque: quid nos dura refugimus / Aetas? quid intactum nefasti / Liquimus? unde manus juventus / Metu Deorum continuit? Quibus / Pepercit aris?" Reproduzimos a tradução que Rosemary Costek Abílio faz da tradução francesa de Pierre Villey.
} 
Montaigne se horroriza principalmente com o espetáculo pavoroso das traições e assassinatos que ele vê grassarem livremente entre seus compatriotas (os casos de perfídia, de quebra da palavra dada, que então deixavam de ser exceção para se tornar regra - um costume geralmente aceito): "Je vois, non une action, ou trois, ou cent, mais des meurs en usage commun et reçeu si monstrueuses en inhumanité sur tout et desloyauté, qui est pour moy la pire espece des vices, que je n'ay point le courage de les concevoir sans horreur; et les admire quasi autant que je les desteste" (III, 9, 956). No século em que o autor escreve seus Ensaios, a dissimulação e o logro haviam se tornado moeda corrente no jogo político, passando a ser considerados peças necessárias da realidade política. O maquiavelismo estava em voga na Itália e fora dela. Após séculos de compreensão da virtude política a partir dos parâmetros da moralidade (o bom governante sendo o líder justo, temperante, prudente, magnânimo, fiel), a virtú do autor de O Príncipe oferecia novos parâmetros para a ação política, afastando-se da phronesis aristotélica (cálculo inseparável das boas disposições morais) e aproximando-se da astúcia, da mentira, da dissimulação, do logro (enfim, da perfídia), que estavam assim autorizados, caso o bem público os exigisse.

Montaigne presencia na prática aquilo que a nova teoria política parecia autorizar. Inúmeros casos de traição, emboscadas e tentativas (bem e mal sucedidas) de assassinato puderam ser contados durante as guerras de religião - todos supostamente a serviço da verdade e do bem comum. Dentre os casos mais notórios estão as tentativas de assassinato dos líderes dos partidos católico e protestante. Em maio de 1560, os huguenotes concebem um plano para matar François de Guise, chefe da Liga dos católicos (a conjuração 
de Amboise, que terminou fracassando e foi punida com severidade por François II). Dois anos depois, uma emboscada durante o cerco de Orléans conseguiu levar a cabo o que os conjurados não haviam conseguido em Amboise: Guise é assassinado. Em julho de 1568, os católicos respondem na mesma moeda, tentando capturar, embora sem sucesso, os líderes protestantes Condé e Coligny no castelo de Noyers e em Tanlay, respectivamente. Mas, os casos mais emblemáticos de perfídia foram justamente aqueles que ocorreram durante as festividades do casamento de Henrique de Navarra e Marguerite de Valois: a tentativa de assassinato de Coligny e o massacre dos líderes protestantes durante a Noite de São Bartolomeu. Neste último caso, o próprio Carlos IX, tomando a decisão e ordenando o assassinato dos líderes huguenotes, rompia os laços de confiança com os súditos e abria um perigoso precedente político, arriscando-se a avalizar, indiretamente, a desobediência do povo.

\subsubsection{Crítica das iniciativas reformistas}

Montaigne experimenta uma forte repulsa moral diante dos casos de perfídia ("je n'ay point le courage de les concevoir sans horreur"). EscandalizaIhe o próprio mecanismo desse vício, a perversidade inerente ao ato da traição, em que alguém se vale da boa fé do outro para prejudicá-lo. Apenas uma mente perversa poderia conceber a instrumentalização da fides contra o fiel. A feiúra da perfídia ("la pire espece des vices") é diretamente proporcional à beleza da fides: fé depositada em nós; ato de desprendimento, abertura e generosidade. Como é possível valer-se da confiança que o outro deposita em nós para atacá-lo? A mera imagem da perfídia é insuportável para o homem de 
bem. Mais do que isso: é inconcebível ("je n'ay point le courage de les concevoir"). Daí a aversão de Montaigne misturar-se a uma grande dose de espanto ("[je] les admire quasi autant que je les desteste"). Ele não pode acreditar que seus compatriotas chegaram a tal ponto: "tout [les] est egalement loisible (...) la plus part ne peut meshuy empirer son marché envers nostre justice, d'où naist l'extreme degré de licence" (III, 9, 965).

Contudo, Montaigne recusa a perfídia principalmente por suas implicações políticas. Isto porque a fidelidade aos compromissos estabelecidos, como já sustentava Cícero no De Officiis, fornece as bases para a vida em comum - é a virtude que une os indivíduos em sociedade. Sem ela (isto é, sem que cada indivíduo possa esperar que o outro vá cumprir com os compromissos firmados com ele, respeitando os acordos e as leis que regulam as relações de ambos), não se estabelecem laços entre os indivíduos; não há sociedade. Daí o escândalo ciceroniano e montaigniano diante da perfídia, vício que mina as próprias condições de possibilidade da vida em comum. No De Officiis, Cícero prescreve o respeito aos compromissos estabelecidos até mesmo nos casos mais extremos, como em relação aos indivíduos que outrora nos prejudicaram ou, no caso dos Estados, em relação aos inimigos de guerra. Ele cita o exemplo de Regulus que, feito prisioneiro pelos cartagineses e enviado a Roma para negociar a troca de presos com a promessa de retornar, preferiu voltar para o suplício a quebrar a palavra dada. Montaigne é ainda mais rigoroso na exigência de fidelidade aos compromissos ("Il y a des regles en la philosophie et faulses et molles" - III, 1, p. 801). Tanto um autor como outro tem a mesma preocupação: que a prática reiterada da perfídia desfaça os 
laços de confiança que unem os indivíduos em sociedade e solape as próprias condições da vida em comum.

O avanço da perfídia no contexto das guerras de religião provoca tanta perturbação em Montaigne porque a perspectiva que se lhe apresenta é a da morte iminente do Estado francês: "Ce qui me poise le plus, c'est (...) que le plus voysin mal qui nous menace n'est pas alteration en la masse entiere et solide, mais sa dissipation et divulsion; l'extreme de noz craintes" (III, 9, 961-2). Diante deste horizonte trágico, restar-Ihe-ia apenas buscar motivos de consolo: "il n'en est point de si malotru qui ne trouve mille exemples où se consoler" (III, 9, 960). Montaigne os procura analisando a situação dos demais Estados do mundo conhecido, nos quais ele vê a mesma ameaça de ruína: "Or tournons les yeux par tout: tout crolle autour de nous; en tous les grands estats, soit de Chrestienté, soit d'ailleurs, que nous cognoissons" (III, 9, 961). O autor encontra consolo nesta "solidariedade universal de mal e de ameaça": não apenas os franceses sofrem, mas todos os povos. Este traço comum fornece-lhe ainda mais: Montaigne tenta extrair dele alguma esperança de sobrevivência do Estado. Se todas as nações estão doentes, diz o ensaísta, então nenhuma está; se a doença é um desvio da norma geral e a saúde a conformidade, então a França à beira do colapso, rodeada por países em igual situação, não se encontra enferma:

"Nous n'avons pas seulement à tirer consolation de cette société universelle de mal et de menasse, mais encores quelque esperance pour la durée de nostre estat; d'autant que naturellement rien ne tombe là où tout tombe. La maladie 
universelle est la santé particuliere; la conformité est qualité ennemie à la dissolution." (III, 9, 961)

Montaigne acumula argumentos com vistas a sustentar os ânimos, buscando motivos para ter esperanças da sobrevivência do Estado francês: "Nous ne sommes pas pourtant, à l'avanture, à nostre dernier periode" (III, 9, 959). A dúvida cética é chamada ao combate da certeza do colapso, que talvez não seja mais do que uma conclusão apressada: "Pour nous voir bien piteusement agitez, (...) je ne vay pas soudain me resolvant (...). La conservation des estats est chose qui vray-semblablement surpasse nostre intelligence" (III, 9, 959). O recurso à autoridade dos filósofos também serve de argumento:

"C'est, comme dict Platon, chose puissante et de difficile dissolution qu'une civile police. Elle dure souvent contre des maladies mortelles et intestines, contre l'injure des loix injustes, contre la tyrannie, contre le debordement et ignorance des magistrats, licence et sedition des peuples.” (III, 9, 959)

Sobretudo, há o exemplo de Roma, que suportou os mais diversos e fortes abalos; que resistiu à quase ausência de governo durante o período dos primeiros imperadores (“A peine reconnoit-on l'image d'aucune police!”), e ainda tendo de manter sob controle tantas nações distantes, de tão variados costumes ("si mal affectionnées, si desordonnéement commandées et injustement conquises"). Se Roma pôde sobreviver a tais provas, talvez a França também possa: "Qui se doit desesperer de sa condition, voyant les 
secousses et mouvemens dequoy celuy-là fut agité et qu'il supporta?" (III, 9, 960). Enfim, Montaigne recorre a metáforas para encontrar esperanças em relação à sobrevivência do Estado, que perdeu sua base (a unidade da religião) bem como a costura que unia suas partes (a fides); talvez a antiguidade de suas instituições, diz o ensaísta, assegure sua sobrevivência: "comme les vieux bastimens, ausquels l'aage a desrobé le pied, sans crouste et sans cyment, qui pourtant vivent et se soustiennent en leur propre poix" (III, 9, 960).

Apesar de todos os argumentos, parece difícil crer que o Estado francês ainda dure muito, pois os vícios e crimes de seus cidadãos vêm se prolongando há tanto tempo que já se tornaram costume, moldando a própria face da sociedade civil e do Estado: "nous sommes tantost par la longue licence de ces guerres civiles envieillis en une forme d'estat si desbordée (...) qu'à la verité c'est merveille qu'elle se puisse maintenir" (III, 9, 956). Um Estado que se assenta sobre costumes doentes é ele próprio enfermo e tende a uma vida curta. A perda dos poucos cidadãos de bem, vítimas de traição e de assassinato, colabora igualmente para o enfraquecimento e a morte do Estado francês:

"Le bon monsieur de Pibrac que nous venons de perdre: un esprit si gentil, les opinions si saines, les meurs si douces. Cette perte, et celle qu'en mesme temps nous avons faicte de monsieur de Foix, sont pertes importantes à nostre couronne. Je ne sçay s'il reste à la France dequoy substituer un autre coupple pareil à ces deux gascons en syncerité et en suffisance pour le conseil de nos Roys. C'estoyent ames diversement belles et certes, selon le siecle, rares et belles, chacune en sa forme. Mais 
qui les avoit logées en cet aage, si disconvenables et si disproportionnées à nostre corruption et à nos tempestes?" (III, 9, 957)

Ocorre que Montaigne recusa a tese de que a saúde do Estado depende da qualidade ou do conteúdo dos costumes e das leis. Quaisquer que eles sejam, diz o ensaísta, o Estado pode se manter com saúde e longevidade:

"la societé des hommes se tient et se coust, à quelque pris que ce soit. (...) La necessité compose les hommes et les assemble. Cette cousture fortuite se forme apres en loix; car il en a esté d'aussi farouches qu'aucune opinion humaine puisse enfanter, qui toutesfois ont maintenu leurs corps avec autant de santé et longueur de vie que celles de Platon et Aristote sçauroyent faire." (III, 9, 956-7; grifos nossos)

Montaigne leva o argumento ao extremo recorrendo a uma anedota retirada dos anais da história:

"Le Roy Philippus fit un amas, des plus meschans hommes et incorrigibles qu'il peut trouver, et les logea tous en une ville qu'il leur fit bastir, qui en portoit le nom. J'estime qu'ils dressarent des vices mesme une contexture politique entre eux et une commode et juste societé." (III, 9, 956)

Segundo o ensaísta, a organização de uma sociedade e o funcionamento de um Estado dependem da obediência dos indivíduos aos costumes que vigoram no país e não do conteúdo dos usos. O Estado extrai sua organização e funcionamento (sua forma) da observância aos costumes. Assim como a 
repetição de determinados hábitos molda o corpo e o caráter de um indivíduo, conferindo-lhes uma forma ou 'disposição habitual', do mesmo modo a repetição e a transmissão dos costumes de geração para geração moldam a sociedade e o Estado, conferem-lhes uma forma, uma 'disposição' regular e estável. Esta forma é justamente a 'saúde' do Estado. Pouco importa que forma seja essa e que costumes a engendraram. O importante é que haja uma forma, uma disposição regular e estável; uma sociedade e um Estado que funcionem. E eles funcionam não por causa da qualidade dos valores, formas de sociabilidade e instituições que os constituem, mas por causa do longo trabalho do tempo, que estabelece a autoridade ${ }^{7}$ dos costumes, tornando-os passíveis de reconhecimento e observância.

Sem dúvida, Montaigne acrescenta, podemos conceber racionalmente um Estado ideal (o "melhor regime", fruto das "melhores leis"). Poderíamos até mesmo, hipoteticamente, pretender imprimir esta forma ideal sobre uma coletividade no momento da fundação de um novo Estado. Mas, ela não poderia ser aplicada sobre um Estado existente, nem servir de regra ou alvo com vistas ao qual ele pudesse ser corrigido ('curado'), sob pena de se pôr a perder justamente a sua saúde (sua forma e estabilidade, por mais frágil que ela seja), que depende do longo processo de sedimentação dos costumes. Toda intervenção com vistas a corrigir ou aperfeiçoar um Estado rompe o processo que the dá forma e estabilidade. Em nome de uma 'correção' com

\footnotetext{
${ }^{7}$ É o tempo que estabiliza as formas que constituem a sociedade e o Estado. Quanto mais antigos e imemoriais são os costumes (quanto menos acesso temos à sua origem), tanto mais os tomamos como naturais e necessários, e tanto maior é nossa propensão a segui-los (tanto maior é o seu poder normativo). Cf. Ensaios, I, 23, p.
} 
vistas a uma forma ideal, põe-se a perder sua forma possível; o Estado perde sua antiga forma sem receber uma nova:

"Toutes ces descriptions de police, feintes par art, se trouvent ridicules et ineptes à mettre en practique (...) Telle peinture de police seroit de mise en un nouveau monde, mais nous prenons les hommes obligez desjà et formez à certaines coustumes (...) Par quelque moyen que nous ayons loy de les redresser et renger de nouveau, nous ne pouvons guieres les tordre de leur ply accoustumé que nous ne rompons tout. (...) Non par opinion mais en verité, l'excellente et meilleure police est à chacune nation celle soubs laquelle elle s'est maintenue. Sa forme et commodité essentielle despend de l'usage." (III, 9, 957)

Assim, Montaigne desliza da esperança com vistas à sobrevivência do Estado francês (que não deve perecer apenas porque os costumes se corromperam) para a crítica das iniciativas reformistas (verdadeira causa da dissolução dos Estados). Ele enfatiza o caos que segue as ações dos reformadores: "entreprendre à refondre une si grande masse et à changer les fondements d'un si grand bastiment, c'est à faire à ceux qui pour descrasser effacent, qui veulent amender les deffauts particuliers par une confusion universelle et guarir les maladies par la mort" (III, 9, 958). Os reformadores tentam dar uma nova forma ao Estado, instituir uma nova regularidade. No entanto, entre a derrubada da velha ordem e o tempo em que a nova ordem ganharia regularidade e estabilidade (tornar-se-ia costumeira) há um longo hiato de ausência de forma, um período em que reina o conflito entre as normas (as antigas, que ainda comandam as ações dos indivíduos, habituados 
a elas, e as novas, que surgem como normas estranhas só podem ser obedecidas à força). Abre-se espaço para a desobediência e para punições consideradas injustas à luz dos antigos costumes. Enfim, abre-se caminho para o surgimento de uma figura redentora que prometa pôr fim aos conflitos e restituir a ordem e a justiça perdidas: "Rien ne presse un estat que l'innovation: le changement donne seul forme à l'injustice et à la tyrannie" (III, 9, 958).

Com sua crítica aos reformadores, Montaigne não ignora que os costumes podem se corromper, nem prescreve a resignação aos usos corrompidos. Apenas recomenda que se evitem as iniciativas de mudança, que põem em xeque as regularidades costumeiras que dão forma e estabilidade ao Estado. Se algo vai mal, é porque houve um desvio da disposição habitual (da 'saúde') do Estado. Para corrigi-lo, não se deve propor mudanças ou inovações, que justamente levariam adiante o desvio da disposição habitual, agravando o mal. O caminho a seguir, ao contrário, é o de favorecer o retorno à disposição habitual do Estado, chamar os indivíduos de volta aos costumes, lembrá-los dos princípios que deixaram de seguir: "Quand quelque piece se démanche on peut l'estayer: on peut s'opposer à ce que l'alteration et corruption naturelle à toutes choses ne nous esloingne trop de nos commencemens et principes." (III, 9, 958). Montaigne concebe a 'saúde' e a 'doença' do Estado nos mesmos termos que certas doutrinas da medicina antiga concebiam o equílibrio e os males do corpo: como a regularidade oriunda da repetição dos hábitos e como o desvio da disposição habitual, respectivamente. E da mesma forma como aplica à política as concepções de saúde e doença da medicina, propõe o mesmo tratamento que ela prescreve: "La fin du chirurgien n'est pas de faire mourir la mauvaise chair: ce n'est que 
l'acheminement de sa cure. II regarde au delà, d'y faire renaistre la naturelle et rendre la partie à son deu estre" (III, 9, 958 - grifos nossos).

\subsubsection{Crítica da perfídia: repulsa moral e realismo político. A disconvenance montaigniana.}

A disseminação da perfídia em seu país faz com que Montaigne se sinta fora de lugar, extemporâneo, "disconvenable" (III, 9, p. 956). À sua volta, ele vê uma massa de celerados ("ces babouyns capettes!" - III, 9, p. 993), enquanto os raros homens de bem que ainda restam, igualmente fora do lugar e extemporâneos, vão pouco a pouco caindo, vítimas da própria boa fé ("Le bon monsieur de Pibrac (...) [et le] monsieur de Foix..."). A perda dos poucos homens nos quais Montaigne ainda se reconhecia aumenta o sentimento de inadequação, de desacordo com o próprio tempo - e de solidão. Ao mesmo tempo, a visão do espetáculo pavoroso dos casos de perfídia que vão se acumulando o atormenta: "J'en suis en particulier trop pressé." (III, 9, p. 956). De um lado e de outro, ele se sente impelido a partir em viagem, a buscar em outras paragens costumes melhores, homens de cuja companhia seja-lhe prazeroso e proveitoso desfrutar; enfim, o afastamento da visão do horror: "Si on me dict que parmy les estrangers il y peut avoir aussi peu de santé (...) je respons (...) qu'il est mal-aysé” (III, 9, p. 972).

Do ponto de vista moral, a perfídia provoca repulsa em Montaigne sobretudo porque implica em servidão. Por todos os lados para onde o ensaísta olha, os franceses fazem concessões à realidade política e vão de encontro às suas convicções morais mais profundas, chegando ao ponto da traição e do assassinato de seus compatriotas. Montaigne não admite ceder a 
tal ponto à realidade política. Ele não avaliza as práticas de seus contemporâneos e não aceita pautar-se por regras que sua própria vontade não possa acatar. Ele recusa a heteronomia. Para manter-se íntegro e livre num tempo em que só os pérfidos parecem sobreviver, prefere partir em viagem e afastar-se da França: "l'autre cause qui me convie à ces promenades, c'est la disconvenance aux meurs presentes de nostre estat" (III, 9, p. 956); “je respons ordinairement à ceux qui me demandent raison de mes voyages: que je sçay bien ce que je fuis" (III, 9, p. 972).

As viagens para fora da França no contexto das guerras de religião simbolizam a distância relativa que Montaigne toma da vida política. O autor faz pessoalmente a prova de sua incompatibilidade ("disconvenance") com ela quando tenta aplicar na vida pública os princípios morais que segue em sua vida privada. Neste momento, ele percebe a inconveniência da franqueza na política (da transparência, da falta de 'verniz' e de máscara; da naturalidade típica do homem rústico). Num mundo de dissimulação e de logro, como é o da política, a sinceridade constante não tem lugar. Quem a emprega arrisca-se a fracassar em suas empreitadas, correndo até mesmo grande perigo:

"J'ay autresfois essayé d'employer au service des maniemens publiques les opinions et reigles de vivre ainsi rudes, neufves, impolies ou impollues, comme je les ay nées chez moy ou raportées de mon institution, et desquelles je me sers sinon commodéement au moins seurement en particulier, une vertu scholastique et novice. Je les y ay trouvées ineptes et dangereuses." (III, 9, p. 991) 
Diante da incompatibilidade entre o seu caráter de homem que zela pela própria liberdade nos atos e nas palavras e a vida política, Montaigne prefere se afastar, evitando ocupações e cargos que o mergulhassem diretamente no jogo político:

“Je sens que, si j'avois à me dresser tout à faict à telles occupations, il m'y faudroit beaucoup de changement et de rabillage. Quand je pourrois cela sur moy (et pourquoy ne le pourrois je, avec le temps et le soing?), je ne le voudrois pas. De ce peu que je me suis essayé en cette vacation, je m'en suis d'autant degousté. Je me sens fumer en l'ame par fois aucunes tentations vers l'ambition; mais je me bande et obstine au contraire: At tu, Catulle, obstinatus obdura. On ne m'y appelle guieres, et je m'y convie aussi peu. La liberté et l'oisiveté, qui sont mes maistresses qualitez, sont qualitez diametralement contraires à ce mestier là." (III, 9, p. 992)

Ocorre que esta distância relativa que o ensaísta toma da política tem de ser bem mensurada, porquanto jamais equivale, malgrado a aparência, a um afastamento de todo e qualquer tipo de atividade política (à ruptura em bloco do moralista com 'o mundo da política', condenada como ‘o lugar do vício'). Isto porque Montaigne não permanece insensível aos argumentos do realismo político maquiaveliano. Embora ele reconheça que a fides é o fundamento da vida em comum e que a prática reiterada da perfídia pelos cidadãos arrisca a solapar as próprias bases da sociedade, compreende igualmente que existem circunstâncias excepcionais (casos de necessidade extrema, como aqueles em que a salvação pública está em jogo) nas quais o agente político se vê 
obrigado a quebrar a palavra dada - e que é bom, embora trágico, que ele assim o faça. Como os maquiavelianos de seu tempo, Montaigne sabe que a ação política se dá na história, que ela está submetida às circunstâncias e contingências do tempo e é condicionada por elas; que fatos, eventos, personagens, circunstâncias materiais, enfim, toda e qualquer vicissitude histórica obriga o agente político a se adaptar, a adequar suas ações - e eventualmente a ter de ir de encontro às normas de sua consciência e 'sujar as mãos'. Noutras palavras, Montaigne compreende que o político é um sujeito histórico, não um agente fora do tempo; que ele não pode pretender pautar suas ações por critérios supratemporais e fixos, como são os da moralidade, mas deve saber ceder às exigências das circunstâncias. É exatamente nesta direção que vai sua crítica à inflexibilidade moral de Catão, que se mostrava inconveniente às exigências políticas de sua época:

"La vertu de Caton estoit vigoreuse outre la mesure de son siecle; et à un homme qui se mesloit de gouverner les autres, destiné au service commun, il se pourroit dire que c'estoit une justice, sinon injuste, au moins vaine et hors de saison. (...) Celuy qui va en la presse, il faut qu'il gauchisse, qu'il serre ses couddes, qu'il recule ou qu'il avance, voire qu'il quitte le droict chemin, selon ce qu'il rencontre; qu'il vive non tant selon soy que selon autruy, non selon ce qu'il se propose mais selon ce qu'on luy propose, selon le temps, selon les hommes, selon les affaires." (III, 9, p. 991 - grifos nossos)

Sensível aos argumentos do realismo político maquiaveliano, o autor dos Ensaios compreende ainda que o agente político é o sujeito em relação ("qui va 
en la presse"), que participa de uma comunidade e deve portanto aprender a negociar, ceder ("gauchisser", "serrer ses couddes", "reculer ou avancer") e até mesmo eventualmente ir de encontro às normas de sua consciência ("quitter le droict chemin"), conforme as condições e os limites que o outro impõe às suas ações ("selon ce qu'on luy propose"). Assim como os maquiavelianos, Montaigne entende que o outro também tem exigências, projetos e interesses (que nem sempre são nobres e) que põem limites às ações e projetos do agente político. Ele percebe, enfim, que a ação na esfera pública ("vie commune", campo de relações), exige que o agente abandone a pretensão de se pautar somente por seus próprios princípios ("vivre selon soy", "selon ce qu'il se propose") e se submeta ao duro aprendizado das concessões, para que possa, enfim, realizar alguma coisa (aquilo que os outros permitem-lhe realizar; o possível naquele momento e diante daqueles homens).

Enfim, Montaigne aprende com o maquiavelianismo que o político deve ser capaz de se adaptar à realidade do mundo humano, à imperfeição constitutiva dos homens, isto é, ao seu caráter "mesclado" (misto de virtude e vício, ideais nobres e interesses excusos, bondade e maldade), pois ele vive no mundo dos homens, em meio aos homens, devendo portanto estar preparado para lidar com as mentiras, as trapaças, a dissimulação e o logro. Para tanto, o político não pode pretender se manter sempre íntegro, falar sempre a verdade, agir sempre retamente; caso contrário, será vítima das artimanhas dos outros homens. Ao contrário, ele próprio deve ser "meslé" (devendo investir-se de uma virtude "mista"), sabendo também fingir e recorrer a artimanhas quando necessário; somente assim responderá adequadamente ao caráter e às intenções "mescladas" dos outros homens: 
"La vertu assignée aus affaires du monde est une vertu à plusieurs plis, encoigneures et couddes, pour s'apliquer et joindre à I'humaine foiblesse, meslée et artificielle, non droitte, nette, constante, ny purement innocente." (III, 9, p. 991)

Em suma, o que o maquiavelianismo mostra (e que Montaigne endossa) é que a retidão de caráter, a inflexibilidade e a constância morais são inconvenientes para a atividade política - que, em circunstâncias extremas, pode exigir que o agente "saia do reto caminho": "les affaires d'estat ont des preceptes plus hardis!" (III, 9, p. 991). À luz disso (isto é, à luz dos apelos das circunstâncias) a inflexibilidade moral do virtuoso é inoportuna (é vaidade, tolice). A este homem que quer se manter puro, imaculado, Montaigne só pode recomendar então que ele se afaste da vida política, do mundo das relações; enfim, que vá viver sozinho:

"Qui a ses meurs establies en reglement au dessus de son siecle, ou qu'il torde et émousse ses regles, ou, ce que je luy conseille plustost, qu'il se retire à quartier et ne se mesle point de nous." (III, 9, p. 993)

Mas se é assim, e quanto ao próprio Montaigne? Qual é o seu lugar em relação à política? Ele é o moralista que, esforçando-se para manter-se íntegro e livre, rompe com a vida pública e retira-se em isolamento? Ou é o homem que considera legítimas as exigências da política e concorda em se lhes submeter, aceitando praticar a perfídia? Ele é o político que expulsa o moralista do convívio dos homens ou é o moralista que se retira? Lembremos que 
Montaigne aponta a incompatibilidade entre a sua própria liberdade, que ele se esforça por manter, e a atividade política, que implica em heteronomia (em dobrar-se às circunstâncias e aos limites que o outro nos impõe); lembremos as decepções que ele diz ter experimentado quando participou ativamente da vida pública ("je m'en suis d'autant degousté") e todo o esforço que alega para evitar o retorno à arena política ("je m'y convie aussi peu”). Tudo se passa como se o jogo político fosse baixo demais para ele; como se ele fosse o moralista destinado ao retiro. Ocorre que a incompatibilidade entre o seu caráter e a vida política também pode ser vista em sentido inverso. Examinando suas próprias disposições morais Montaigne subitamente percebe-se semelhante a Catão; não tanto pela perfeição moral, da qual considera-se muito distante, mas pela vaidade de não aceitar fazer concessões num tempo em que o rigorismo moral é inadequado (o tempo em que a Monarquia francesa, como outrora a República romana, sofre o risco da dissolução):

"La vertu de Caton estoit vigoreuse outre la mesure de son siecle; et à un homme qui se mesloit de gouverner les autres, destiné au service commun, il se pourroit dire que c'estoit une justice, sinon injuste, au moins vaine et hors de saison. Mes moeurs mesmes, qui ne disconviennent de celles qui courent à peine de la largeur d'un poulce, me rendent pourtant aucunement farouche à mon aage, et inassociable. Je ne sçay pas si je me trouve desgousté sans raison du monde que je hante, mais je sçay bien que ce seroit sans raison si je me pleignois qu'il fut desgouté de moy plus que je le suis de luy." (III, 9, p. 991) 
O reconhecimento da vaidade do rigorismo moral leva, então, Montaigne a abandonar a via do moralista e tomar a trilha do político, a aceitar fazer as concessões que as circunstâncias the obrigariam e, enfim, adequar-se? Não. Entre a adequação e a inadequação, Montaigne opta pela última; mas não mais sob o exemplo da vaidade orgulhosa de um Catão, que se considerava melhor que o seu tempo e que escolheu abandoná-lo, e sim à luz do modelo de um Sócrates, que permaneceu deslocado entre os seus contemporâneos ao longo de toda a sua vida, mas nem por isso os abandonou; ao contrário, permaneceu entre eles, até que sua inadequação os levou a sacrificá-lo:

"Estoit-il à croire que Socrates eust appresté aux Atheniens matiere de rire à ses despens, pour n'avoir onques sçeu computer les suffrages de sa tribu et en faire raport au conseil? Certes la veneration en quoy j'ay les perfections de ce personnage merite que sa fortune fournisse à l'excuse de mes principales imperfections un si magnifique exemple." (III, 9, p. 992)

O exemplo de Sócrates torna a incompetência montaigniana para a política 'perdoável'. A ironia desta passagem reside no fato de que o verdadeiro defeito não está nesta 'imperfeição' de Sócrates e de Montaigne, mas, justamente ao contrário, nas pretensas perfeições de que ambos desejam fugir: na suposta perfeição de caráter de um Catão, que o leva à ruptura com o mundo dos homens, e na pretensa adequação perfeita do político às circunstâncias, que leva tantos indivíduos, sem perceber, ao crime. Comparada a tais extremos, a imperfeição socrático-montaigniana talvez seja virtude. Em 
relação ao mundo dos homens, ela não é nem a total inadequação de um Catão nem a absoluta adequação do político. Montaigne, como Sócrates, permanece no meio de seus contemporâneos, sendo ao mesmo tempo diferente deles. Mantém-se à distância do jogo político, mas não totalmente fora da política. Ele ocupa este estranho lugar que é o lugar do filósofo; reivindica esta capacidade que não é aptidão para a política, mas não deixa de ter efeitos salutares sobre ela: "tel se conduict bien qui ne conduict pas bien les autres et faict des Essais qui ne sauroit faire des effaicts" (III, 9, p. 992).

\subsubsection{Cosmopolitismo sem Universalismo. As viagens e a abertura para o outro.}

A saída montaigniana da França no contexto das guerras de religião encontra ainda justificação em argumentos cosmopolitas. Diante das pressões que sofre dentro da própria pátria, lançar-se ao mundo parece a Montaigne uma opção bastante justificável. A seu favor, ele alega a anterioridade do nosso vínculo com o mundo e com os demais homens em relação ao laço com a pátria e os compatriotas, bem como o valor maior das relações livremente estabelecidas em comparação com as impostas pelas circunstâncias de nascimento e respeitadas por obrigação:

“j'estime tous les hommes mes compatriotes, et embrasse un Polonois comme un François, postposant cette lyaison nationale à l'universelle et commune. Je ne suis guere feru de la douceur d'un air naturel. (...) Les amitiez pures de nostre acquest emportent ordinairement celles ausquelles la communication du climat ou du sang nous joignent. Nature nous a mis au monde 
libres et desliez; nous nous emprisonnons en certains destroits (...) par sottise" (III, 9, p. 973)

Montaigne faz a crítica da naturalização dos costumes, que compromete a liberdade dos homens e torna impossível o estabelecimento de relações com o outro. Na contramão da tendência geral da época, ele revela o gosto pelas viagens e pela diferença, que teria conquistado justamente por seus passeios por outras paragens, que o teriam desprendido de seus próprios usos e o tornado permeável aos costumes alheios:

"le voyager me semble un exercice profitable. L'ame y a une continuelle exercitation à remarquer les choses incogneues et nouvelles; et je ne sçache point meilleure escolle, comme j'ay dict souvent, à former la vie que de luy proposer incessamment la diversité de tant d'autres vies, fantasies et usances, et luy faire gouster une si perpetuelle varieté de formes de nostre nature." (III, 9, p. 973)

"J'ay honte de voir noz hommes enyvrez de cette sotte humeur de s'effaroucher des formes contraires aux leurs (...) Où qu'ils aillent, ils se tiennent à leurs façons, et abominent les estrangeres. Retrouvent ils un compatriote en Hongrie? (...) les voylà à se ralier et à se recoudre ensemble, à condamner tant de meurs barbares qu'ils voient." (III, 9, p. 986)

"Au rebours, je peregrine tres-saoul de nos façons, non pour cercher des Gascons en Sicile (j'en ay assez laissé au logis); je cerche des Grecs plustost, et des Persans: j'acointe ceux-là, je 
les considere; c'est là où je me preste et où je m'employe." (III, 9, p. 986)

Tudo se passa, até aqui, como se Montaigne reivindicasse um vínculo natural com o mundo e com a humanidade como um laço superior ao vínculo parcial e costumeiro com a pátria e os compatriotas; tudo se passa como se ele recomendasse a experiência reiterada dos diferentes costumes como uma prática capaz de nos fazer reconhecer, para além de suas determinações parciais, o elemento racional e natural que eles compartilham, o que nos desprenderia dos nossos usos e nos tornaria permeáveis aos costumes alheios. Nada mais distante do que Montaigne está dizendo efetivamente, malgrado as aparências e o uso constante de termos típicos do discurso naturalista-essencialista ("Nature", "Iyaison universelle et commune" etc.), instrumentalizado intencionalmente pelo ensaísta com vistas a sustentar o discurso oposto, corroborado pelo efeito irônico do expediente retórico-poético. Longe de recomendar a experiência dos diferentes costumes para que reconheçamos, para além de suas determinações parciais, o elemento racional e natural que eles compartilhariam, Montaigne a recomenda para que reconheçamos que só há determinações parciais (e que os nossos próprios costumes, portanto, são tão contingentes quanto os alheios). Montaigne recomenda menos a experiência do que os costumes tem em comum do que a do que eles tem de diferente $^{8}$, experiência que teria por efeito não tanto a

\footnotetext{
${ }^{8}$ Nossa leitura, assim, diverge da interpretação que Géralde Nakam (Les Essais, Miroir et Procès de leur Temps, p. 413-19) dá ao cosmopolitismo de Montaigne, na medida em que o acento da comentadora recai sobre "os laços dos homens entre si, sua indestrutível unidade"
} 
estabilização de alguma coisa quanto a contínua desestabilização dos hábitos do indivíduo, que não devem naturalizar-se:

"L'ame y a une continuelle exercitation à remarquer les choses incogneues et nouvelles (...) la diversité de tant d'autres vies, fantasies et usances (...) une si perpetuelle varieté de formes" (III, 9, p. 973-4; grifos nossos)

“je cerche des Grecs plustost, et des Persans: j'acointe ceux-là, je les considere; c'est là où je me preste et où je m'employe." (III, 9, p. 986; grifos nossos)

que Montaigne faria ver, pois encontraria no outro nada mais do que um "outro si mesmo, que o instrui sobre si mesmo". Os outros, diz Nakam, são "formas de nossa natureza" diferentemente desenvolvidas. "Cada um deles está em cada um de nós, e nos enriquece se o reconhecemos." (idem, p. 414) Esta é a verdade que "funda a antropologia dos Ensaios", prossegue a comentadora. "Cada ser é o fruto de uma "mistura" e porta em si, não somente em espírito e em potência, mas materialmente e em verdade, "a forma inteira [...] da humana condição" (idem, p. 412). Daí a postura tolerante de Montaigne e disponível à experiência do que the é "estranho". "Os outros expulsam o estranho de perto deles e deles mesmos. Montaigne o instala em si” (idem). Enfim, para o viajante cosmopolita que é Montaigne, na visão da intérprete, nada é estranho, a ele que "habita o universo". Seu pertencimento à humanidade, reconhecido, leva-o a acusar todo particularismo e limite das "fronteiras mentais da intolerância" dos homens do tempo e convida-os a "se libertar". Em resumo: Nakam pretende fundar a abertura montaigniana para o outro sobre a noção de condição humana. Nós, por sua vez, acreditamos que a proposta do ensaísta é ainda mais radical, posto que somente a experiência reiterada da diferença pode fundar uma abertura efetiva para a alteridade. Buscar no outro a condição humana é novamente buscar-me no outro, abrir-me para o outro na medida em que me vejo nele. Montaigne, segundo entendemos, não opõe o comum (seja natureza, seja condição) ao próprio, mas o outro ao mesmo. 
Ora, mas se é assim, o cosmopolitismo defendido por Montaigne possui um inestimável valor político, na medida em que representa uma abertura efetiva para a alteridade, e não uma falsa abertura, que se baseia numa relação estabelecida entre diferentes na medida em que eles compartilham algo em comum (isto é, na medida em que não são totalmente diferentes). O exercício de flexibilização dos próprios costumes (numa palavra, de flexibilização do próprio) tem por efeito muito mais do que produzir o homem do mundo: ele engendra o verdadeiro político, isto é, o homem não só capaz de acatar o outro como mesmo de buscá-lo: "c'est là où je me preste et où je m'employe".

A defesa da perspectiva cosmopolita, enfim, não equivale a uma recusa do patriotismo, mas apenas a recolocá-lo no seu devido lugar, temperando a relação com a pátria por meio da recusa da adesão apaixonada aos próprios costumes e valores ("je ne suis guere feru de la douceur d'un air naturel"). Enquanto abertura para o outro, ela tem efeitos ainda sobre as relações entre os próprios compatriotas, entre os quais também há diferenças e dissensões, bem como grupos que se opõem. De tal forma que o cosmopolitismo alegado por Montaigne como argumento para deixar a pátria durante as guerras de religião acaba por ser uma resposta direta ao mal que dilacera a França por dentro, isto é, à estreiteza e à parcialidade dos partidos católico e protestante, cujos membros apaixonados tornam impossível uma solução moderada. Montaigne abordará este ponto no ensaio De poupar a própria vontade. Ele não tem dúvidas quanto ao partido correto: o católico, herdeiro da tradição e do costume. Está seguro de que o partido errado é o que vem a romper com a legalidade costumeira que dá forma ao Estado. No entanto, abre-se para uma 
convivência pacífica com os novos costumes que começam a se estabelecer por todo o país.

\subsection{A conveniência na proximidade da morte. Crítica dos rituais de despedida.}

Enfim, a perfídia representa um risco à vida de Montaigne. No momento em que escreve o ensaio, católicos estão sendo massacrados por protestantes. A recente perda dos amigos Pibrac e De Foix escandaliza o ensaísta e o faz tomar consciência de que talvez seja o próximo a cair. Sem dúvida, o respeito que dedicava aos vizinhos e a liberdade e a generosidade com que tratava os habitantes de sua região tornavam favoráveis as opiniões e humores a seu respeito e afastavam, a princípio, os perigos: "Comme maison de tout temps libre, de grand abbord, et officieuse à chacun (...), ma maison a merité assez d'affection populaire, et seroit bien malaisé de me gourmander sur mon fumier" (III, 9, p. 965). Montaigne se regozija por sua casa ser a única da região que não sofreu nenhuma violência até então: "et [je] estime à un merveilleux chef d'oeuvre, et exemplaire, qu'elle soit encore vierge de sang et de sac, soubs un si long orage, tant de changemens et agitations voisines." A violência entre os partidos, no entanto, não dá mostras de arrefecimento, levando o ensaísta a ver-se em permanente perigo - o risco de morte é iminente: "les invasions et incursions contraires et alternations et vicissitudes de la fortune autour de moy ont jusqu'à cette heure plus exasperé que amolly l'humeur du pays" (III, 9, p. 965-6). 
A propriedade de Montaigne encontra-se numa região particularmente propícia aos confrontos; nestas paragens, diz o ensaísta, a violência nunca cessa, a turbulência jamais arrefece, a tranquilidade nunca se faz presente: "Le lieu où je me tiens est tousjours le premier et le dernier à la batterie de nos troubles, et où la paix n'a jamais son visage entier" (III, 9, p. 971). No momento em que escreve estas linhas, a agitação não permanece fora do castelo: ela atravessa seus portões e adentra a casa de Montaigne sob a forma do medo. O autor se vê cada vez mais acuado em sua fortaleza, apavorado com a perspectiva da morte iminente: "Je me suis couché mille foys chez moy, imaginant qu'on me trahiroit et assommeroit cette nuict là, composant avec la fortune que ce fut sans effroy et sans langueur" (III, 9, p. 970). O horror frente à violência geral e o medo diante da perspectiva da própria morte invadem o lar de Montaigne. Mesmo deste refúgio a paz foi sequestrada. $\mathrm{O}$ autor lamenta profundamente o contínuo terror a que se vê submetido dentro de sua própria casa: "Les guerres civiles ont cela de pire que les autres guerres, de nous mettre chacun en eschauguette en sa propre maison. (...) C'est grande extremité d'estre pressé jusques dans son mesnage et repos domestique." (III, 9, p. 971)

Diante da perspectiva do pior, Montaigne busca razões para ter esperanças. Até mesmo imagens e aproximações poéticas valem no esforço de confiar: oxalá os assassinos que rodeiam seu castelo aspirassem todos os males do ar e o purificassem de todos os vícios, afastando todos os perigos!, "comme disent aucuns jardiniers, que les roses et violettes naissent plus odoriferantes pres des aulx et des oignons, d'autant qu'ils sucent et tirent à eux 
ce qu'il y a de mauvaise odeur en la terre" (III, 9, 971). Mas há poucos motivos para ter esperanças. Resta ao autor buscar argumentos de consolo:

"mais de cecy il en peut estre quelque chose: que la bonté est plus belle et plus attraiante quand elle est rare" (...)

Ou então,

"Nostre fièvre est survenue en un corps qu'elle n'a de guere empiré: le feu y estoit, la flamme s'y est prinse; le bruit est plus grand, le mal de peu." (III, 9, p. 972)

Ironicamente, o próprio medo da morte termina conduzindo Montaigne a algo parecido com a tranquilidade que os filósofos inutilmente procuram conquistar por meio da razão. Diante do terror permanente em que vive, uma morte violenta e breve ("numa investida súbita"; "de um salto e num instante"), que desse lugar imediatamente ao nada (à absoluta insensibilidade e ausência de sofrimento), torna-se inesperadamente desejável. Talvez o único modo de se alçar a algo semelhante à firmeza buscada pelos filósofos seja finalmente através do medo - do terror levado ao limite, e da vontade de nele pôr fim:

"Je tire par foys le moyen de me fermir contre ces considerations de la nonchalance et lacheté: elles nous menent aussi aucunement à la resolution. II m'advient souvant d'imaginer avec quelque plaisir les dangiers mortels et les attendre: je me plonge la teste baissée stupidement dans la mort, sans la considerer et recognoistre, comme dans une profondeur muette et obscure qui m'engloutit d'un saut et accable en un instant d'un puissant sommeil plein d'insipidité et indolence. Et en ces morts courtes et 
violentes, la consequence que j'en prevoy me donne plus de consolation que l'effait de trouble." (III, 9, p. 971)

A idéia da própria aniquilação e desaparecimento é por princípio insuportável; o medo da morte, incontornável. Inutilmente, as escolas de filosofia pretenderiam afastar o temor por meio de uma premeditação que tencionasse nos habituar à idéia da morte - torná-la 'familiar'. Somente quando a vida se torna insustentável (quando o sofrimento que se experimenta torna-se maior do que o medo de perdê-la) é que alguma firmeza diante da perspectiva da própria morte torna-se possível. Nestas circunstâncias extremas, nem mesmo cabe falar de 'firmeza' ou 'tranquilidade' - a morte, antes, é o bálsamo para todos os males.

O risco iminente de morte dá a Montaigne o ensejo para uma reflexão sobre os limites da firmeza e o único recurso que talvez nos reste diante da perspectiva do nosso próprio fim: aliviar suas circunstâncias. Se não é possível mantermo-nos tranquilos no momento da nossa própria morte, talvez seja possível, ao menos, tornar o morrer um pouco menos doloroso, afastando outras causas de sofrimento. Montaigne desenvolve este ponto quando responde aos que o acusavam de inconveniência por viajar na velhice, arriscando-se a morrer longe de casa e a deixar de cumprir com seu último grande dever: "despedir-se dos amigos" (III, 9, p. 978). O autor thes responde que, se pudesse escolher, preferiria morrer assim: em terras estrangeiras e em meio a estranhos, pois então evitaria todo o sofrimento do ritual de despedida pouparia a si mesmo e a seus familiares das lágrimas e das palavras inúteis de 
consolo. Assim, ao mesmo tempo em que inverte a acusação, apontando a inconveniência do ritual de despedida, Montaigne revela o desejo de uma morte menos sofrida: "plustost à cheval que dans un lict, hors de ma maison et esloigné des miens" (III, 9, 978).

Montaigne começa a responder aos críticos narrando o sofrimento do moribundo em meio ao ritual de despedida. Na cama, cercado de parentes, amigos e figuras cuja amizade é suspeita, ele não tem sossego; ajeitam-no, dão-lhe beberagens, falam com ele sem cessar: "I'un tourmente vos yeux, l'autre vos oreilles, l'autre la bouche; il n'y a sens ny membre qu'on ne vous fracasse" (III, 9, p. 978). Pessoas entram e saem incessantemente do quarto. Uma multidão rodeia a cama. Há movimento demais, barulho demais, cuidados demais: a assistência é excessiva e inconveniente. Há também a tristeza provocada pelos lamentos dos amigos e dos parentes, e a raiva pelas lágrimas fingidas de alguns: "Le coeur vous serre de pitié d'ouyr les plaintes des amis, et de despit à l'avanture d'ouyr d'autres plaintes feintes et masquées" (III, 9, p. 978). Além do pavor com a perspectiva da própria morte, o moribundo é atormentado por emoções provocadas pelos outros: "j'ay assez affaire à me consoler sans avoir à consoler autruy, assez de pensées en la teste sans que les circonstances m'en apportent de nouvelles" (III, 9, p. 979). E ainda esperase dele serenidade! Montaigne recusa tal pretensão. Diz-se incapaz de firmeza numa tal circunstância: "Ce n'est pas mon advis de faire en cette action preuve ou montre de ma constance" (III, 9, p. 978). "Para quê", acrescenta com ironia, "se então cessará todo interesse que tenho à reputação?” (III, 9, p. 979).

O moribundo não é o único a sofrer com o ritual de despedida. A dor dos amigos e parentes é imensa. Montaigne gostaria de partir em viagem e morrer 
longe de casa não apenas para se poupar, mas ainda para poupar aos seus. Ele acusa a insensatez de certos doentes, que valorizam os próprios males para incitar a compaixão nos amigos: "Nous faisons valoir nos inconveniens outre leur mesure, pour attirer leurs larmes. (...) Nous ne nous contentons pas qu'ils se ressentent de nos maux, si encores ils ne s'en affligent" (III, 9, p. 979). "Humor pueril e desumano!", avalia o autor. Melhor seria nos afastarmos dos entes queridos nas nossas últimas horas para poupá-los da dor: "Il faut estendre la joye, mais retrencher autant qu'on peut la tristesse. (...) Vivons et rions entre les nostres, allons mourir et rechigner entre les inconneus" (III, 9, 979).

Antes mesmo dos momentos finais de despedida, a própria velhice e as doenças que a acompanham já são um peso para a família. Acometido há anos pelos cálculos renais, Montaigne lamenta importunar seus parentes há tanto tempo com suas queixas e gemidos, a ponto de insensibilizá-los ao seu sofrimento: "Vous apprenez la cruauté par force à voz meilleurs amis, durcissant et femme et enfans, par long usage, à ne sentir et plaindre plus vos maux. Les souspirs de ma cholique n'apportent plus d'esmoy à personne" (III, 9, p. 981). Ele descreve a inconveniência do velho que passa os dias a resmungar e gemer, reclamando dos próprios males: "A qui ne se rendent-ils en fin ennuyeux et insupportables?" (III, 9, p. 981). Pouco a pouco, suas queixas e gemidos vão minando o prazer da convivência, até restar apenas raiva e ressentimento: "Plus je les verrois se contraindre de bon coeur pour moy, plus je plainderois leur peine.” (III, 9, p. 981). Daí, a recomendação do afastamento - que o velho deixe sua família em paz e poupe-a de tanta dor: "La decrepitude est qualité solitaire. (...) il [est] raisonnable que meshuy je 
soustraye de la veue du monde mon importunité, et la couve à moy seul, que je m'appile et me recueille en ma coque, comme les tortues. (...) II est temps de tourner le dos à la compagnie.” (III, 9, p. 982)

Os deveres ordenam que a família cuide dos seus durante o tempo que for necessário, que os assista até o seu último suspiro e finalmente lamente e chore sua morte à beira da cama. Determinam que o velho doente permaneça junto aos amigos e parentes nos seus últimos momentos, despedindo-se e dando provas de firmeza ao longo de todo o processo. Montaigne acusa a inconveniência destes deveres, a crueldade a que submetem a família e o indivíduo já fragilizado pela velhice e pela doença: "Les offices communs n'en vont point jusques là" (III, 9, p. 981). Ele acusa o velho que exige os cuidados da própria família durante tempo demais de abusar de seus direitos: "n'est-ce pas trop d'en abuser tout un aage? (...) Nous avons loy de nous appuyer, non pas de nous coucher si lourdement sur autruy et nous estayer en leur ruyne" (III, 9, p. 981). Por outro lado, diz que lhe pedimos demais quando exigimos que se submeta ao ritual de despedida: "J'oublie volontiers ce devoir de nostre entregent, car des offices de l'amitié celuy-là est le seul desplaisant (...) j'ay assez affaire à me consoler sans avoir à consoler autruy" (III, 9, p. 978-9). No lugar desses deveres, o velho Montaigne gostaria de seguir uma outra conduta, que lhe parece mais conveniente (mais humana, menos cruel): afastar-se de sua própria família e deixá-la em paz, buscando em outras paragens um pouco de tranquilidade nos seus últimos momentos ("une mort recueillie en soy, quiete et solitaire" - III, 9, p. 979).

Eis como Montaigne gostaria de morrer: em terras estrangeiras e em meio a estranhos, para os quais sua morte seria indiferente. De preferência, 
sendo assistido por alguém que cobrasse por seus serviços, e não por quem os fizesse por obrigação moral (sobre quem sentiria que pesaria e em relação a quem não teria toda a liberdade): "On trouve, en payant, qui vous tourne la teste et qui vous frote les pieds, qui ne vous presse qu'autant que vous voulez, vous presentant un visage indifferent, vous laissant vous entretenir et plaindre à vostre mode." (III, 9, p. 979). Finalmente, gostaria de morrer num lugar confortável, mas sem luxo: "Je veus estre logé en lieu qui me soit bien particulier, sans bruict, non sale, ou fumeux, ou estouffé. (...) je n'y mesle pas la pompe et l'amplitude: je la hay plustost; mais certaine proprieté simple" (III, 9, p. 983-5). Dessa forma, o ensaísta esperaria tornar seu próprio fim um pouco menos sofrido. Na medida em que a firmeza no enfrentamento da morte é-lhe impossível, restar-lhe-ia evitar acrescentar-Ihe outras causas de sofrimento: "Je cherche à flatter la mort par ces frivoles circonstances, ou, pour mieux dire, à me descharger de tout autre empeschement, affin que je n'aye qu'à m'attendre à elle, qui me poisera volontiers assez sans autre recharge" (III, 9, p. 983).

Assim, Montaigne esperaria tornar sua morte coerente com sua vida; procuraria não romper com o modo como se conduziu até então: buscando sempre, dada sua fraqueza insuperável, aliviar o peso dos obstáculos, contornar as dificuldades: "Je veux qu'elle [la mort] ayt sa part à l'aisance et commodité de ma vie. Ce en est un grand lopin, et d'importance, et espere meshuy qu'il ne dementira pas le passé" (III, 9, p. 983). Ele se apropria e faz sua a exigência estóica da perfeita coerência consigo mesmo (do não desmentir-se; da inabalável constância de propósitos), mas a preenche com 
um conteúdo radicalmente oposto ${ }^{9}$, recusando o ideal da firmeza e buscando reduzir ${ }^{10}$ os tormentos no momento da morte por uma via mais humana (a do homem medíocre).

\footnotetext{
${ }^{9}$ Parece-nos vir daí a dificuldade de parte da tradição do comentário em chegar a um acordo sobre a posição do autor relativamente ao estoicismo. Os intérpretes ora classificam Montaigne
} como estóico, ora recusam-Ihe o pertencimento à escola porque ora identificam a apropriação de certos temas e preceitos da stoa ora reconhecem críticas contundentes à escola e a adoção de condutas e teses contrárias ao estoicismo. Ocorre que Montaigne, segundo pensamos, põe em prática ambos os expedientes: ele se apropria de certos esquemas estóicos (de certas estruturas formais) e as preenche com um conteúdo avesso ao que a escola lhe dava (dota-as de um significado oposto ao que os estóicos lhe davam). Daí o dissenso entre os comentadores; daí alguns chegarem mesmo a falar de uma "contradição montaigniana". Mas, Montaigne não se contradiz quando reivindica a coerência estóica e, ao mesmo tempo, a falta de firmeza de alma do homem medíocre (talvez de inspiração horaciana). Apenas preenche um esquema extraído de uma escola com o conteúdo retirado de outra. Enfim, isto sequer compromete a tese (com a qual, aliás, concordamos) do ceticismo do autor dos Ensaios (pois Montaigne se apropria de esquemas formais, de tópicas com as quais ele não tem nenhum compromisso doutrinário - tomando-as apenas como opiniões reputadas). Apenas, acreditamos que falta aos comentadores que enfatizam o ceticismo montaigniano reconhecer a importância das outras escolas helenísticas (e mesmo helênicas) para a obra do autor, bem como explicar os mecanismos através dos quais o autor pode se apropriar (sem prejuízo da coerência interna de sua obra) de temas, categorias e preceitos dessas escolas, sem que isto traga prejuízo algum para as suas convicções céticas. Entendemos que frequentemente tais comentadores equivocam-se ao pretender explicar a obra montaigniana única e exclusivamente por meio de categorias derivadas das obras dos céticos.

${ }^{10}$ Trata-se apenas de uma redução dos tormentos, que não podem ser eliminados. Montaigne não aceita entregar-se à perturbação, como faz o vulgo, nem pretende alcançar uma perfeita tranquilidade, como quer o sábio. Ele insiste na posição intermediária do homem medíocre que procura, lançando mão dos poucos recursos de que dispõe (não a firmeza, mas uma 
Montaigne sabe que as circunstâncias da morte tem muito pouco significado em comparação com a própria morte (com a perspectiva da própria aniquilação e desaparecimento - este, sim, o fato grave), mas não pode deixar de se preocupar com a maneira como deve morrer (deixar de temer o sofrimento durante seus últimos momentos). Contra os críticos que lhe acusam de tolice ("Tant sottement nostre crainte regarde plus au moyen qu'à l'effect" III, 9, p. 984) e apontam a indiferença do tipo de morte, Montaigne diz que não pode deixar de sentir tal diferença. Mais uma vez, ele recusa a avaliação puramente racional e destituída de páthos do sábio estóico e afirma sua condição de homem medíocre, incontornavelmente afetado pela paixão (no caso, pelo medo): “j'imagine plus mal aiséement un precipice qu'une ruine qui m'accable et un coup tranchant d'une espée qu'une harquebousade (...) Et, quoy que ce soit un, si sent mon imagination difference comme de la mort à la vie" (III, 9, p. 984).

Ora, se mesmo as circunstâncias da nossa própria morte podem nos trazer sofrimento, talvez possamos, no entanto, aliviá-las (já que não podemos evitar a própria morte): "La mort a des formes plus aisées les unes que les autres, et prend diverses qualitez selon la fantasie de chacun. (...) puisque chacun a quelque chois entre les formes de mourir, essayons un peu plus avant d'en trouver quelqu'une deschargée de tout desplaisir" (III, 9, p. 983-4). Montaigne lembra os exemplos extremos daqueles que chegaram até mesmo a mesclar alguma volúpia ao próprio morrer ("comme les commourans d'Antonius et de Cleopatra..." - III, 9, p. 984) e prescreve que aprendamos com eles a

capacidade de desviar-se das dificuldades), evitar ou reduzir um pouco a perturbação. Montaigne busca, o tempo todo e em todas as esferas, a melhor conduta possível. 
tornar nossa morte menos dolorosa, mas sem chegarmos a tal extremo desonroso: "Ne sçaurions nous imiter cette resolution en plus honneste contenance?" (III, 9, p. 984). Assim como não espera que cheguemos a dar mostras de virtude ao morrer, também não deseja que incorramos no vício: "Puis qu'il y a des mors bonnes aux fols, bonnes aux sages, trouvons en qui soyent bonnes à ceux d'entre deux" (III, 9, p. 984).

Eis a conduta a ser ensaiada pelo homem comum: não a indiferença em relação às circunstâncias da morte e à própria morte, mas a busca de um morrer menos sofrido, de um fim menos doloroso ("essayons (...) d'en trouver quelqu'une [mort] deschargée de tout desplaisir"). Sem dúvida, a tentativa pode fracassar, já que temos muito pouco poder sobre as circunstâncias da nossa própria morte, como, de resto, sobre toda a nossa vida: "Mais Theophraste, philosophe si delicat, si modeste, si sage, a il pas esté forcé par la raison d'oser dire ce vers latinisé par Ciceron: Vitam regit fortuna, non sapientia[?]" (III, 9, p. 984). Mas pelo menos podemos tentar - ao menos o ensaio está sob o nosso poder. Quanto ao homem de idade avançada, que já se encontra perto do próprio fim, resta-lhe narrar sua boa ou má fortuna (e agradecê-la ou lamentála):

"Combien aide la fortune à la facilité du marché de ma vie, me l'ayant logée en tel poinct qu'elle ne faict meshuy ny besoing à nul, ny empeschement. C'est une condition que j'eusse acceptée en toutes les saisons de mon aage, mais en cette occasion de trousser mes bribes et de plier bagage, je prens plus particulierement plaisir à ne faire guiere ny de plaisir ny de desplaisir à personne en mourant. Elle a, d'une artiste conpensation, faict que ceux qui peuvent pretendre quelque 
materiel fruict de ma mort en recoivent d'ailleurs conjointement une materielle perte." (III, 9, p. 984)

\section{Recusa da autarquia estóica. Conhecer e lidar com os próprios condicionamentos.}

Até aqui nós mostramos que as viagens de Montaigne são concessões oportunas que ele faz às paixões que o acometem. Por meio delas, o ensaísta consegue simultaneamente atender às demandas dos afetos e da razão, aos imperativos do prazer e do dever. Mostramos que Montaigne possui um senso de conveniência que the permite discernir as ocasiões em que ceder aos afetos não apenas não contraria os deveres como o permite realizá-los de maneira ainda mais rigorosa. Vimos como isso se dá na administração doméstica, na esfera política e na iminência da morte. Agora nos resta mostrar que esta relação do ensaísta com as próprias paixões estabelece uma outra forma de liberdade que a perfeita autarquia almejada pelos estóicos.

Para estes, as 'coisas exteriores' (os bens segundo a opinião comum) são fonte de servidão. Aquele que as toma como fins últimos (téloi) de suas ações, isto é, que as busca como condição para sua felicidade, aspira-as sem saber se sua posse está ou não inscrita no seu destino. Assim, pode passar a vida buscando-as sem nunca as alcançar (ou pode acreditar poder mantê-las sendo que está fadado a perdê-las). Ele se escraviza, portanto, a coisas que escapam ao seu poder. Para escapar desta condição servil, os estóicos recomendavam a imitação do modelo do sábio, que busca os bens de opinião, mas mantendo-se indiferente à sua posse ou perda, visto que apenas visa, ao escolhê-los, a própria racionalidade da escolha, única coisa que ele sabe estar 
sob seu poder. Enfim, eles recomendavam a imitação da autarquia do sábio, de sua perfeita independência das coisas exteriores, que ele não toma como condição para sua felicidade.

Montaigne se reconhece incapaz desta perfeita autarquia. Ele não consegue se manter totalmente indiferente e independente das 'coisas exteriores' - e sabe que jamais o conseguirá. Ele não pode deixar de ser afetado por elas, de entristecer-se, de sentir medo, de encolerizar-se, de desejar. Mas, se ele aprende que não pode propriamente suprimir as paixões, percebe que talvez ainda tenha algum controle sobre elas. Ele compreende que pode evitar as circunstâncias, objetos e representações que as despertam, e que pode desviar sua consciência ao menor indício da tormenta, antes que as paixões ganhem corpo e o arrastem, provocando perturbações desnecessárias. Montaigne percebe, enfim, que pode se deixar levar pelos afetos quando assim for conveniente, isto é, quando o medo, a tristeza, a cólera, o desejo e as demais paixões não contrariarem o dever. Mais do que isso, ele compreende mesmo que há certas ocasiões em que os imperativos da razão e do dever e as pressões da paixão convergem, apontam na mesma direção, levam à mesma conduta - e que, nestas circunstâncias, deixar de seguir as paixões é deixar de seguir a razão. Nestes raros momentos preciosos, Montaigne percebe que deve fugir da dor e buscar o prazer.

Mas, se é assim, isto é, se o autor dos Ensaios ainda consegue ter algum controle sobre as paixões que o acometem e evitar ser arrastado por elas e decidir quando pode ceder às suas pressões, então ele é livre. Não porque é perfeitamente independente das 'coisas exteriores', mas porque conhece quais o mantêm em relação de dependência (quais despertam nele o 
desejo, a tristeza, o medo etc.), em que circunstâncias essa dependência assume a forma da servidão (o tempo que as paixões incipientes levam para se tornarem avassaladoras) e como evitá-las. Montaigne é livre não porque não tem condicionamentos, mas porque conhece o que o condiciona. E mesmo esta liberdade não é uma conquista definitiva, mas algo que ele tem de se esforçar cotidianamente para manter; uma liberdade entremeada de episódios de servidão, de momentos de fraqueza, de idas e vindas. Daí sua hesitação quando avalia o poder que o conhecimento do que o condiciona Ihe dá: "ceux qui le sentent en ont un peu meilleur compte, encore ne sçay-je" (III, 9, p. 1000). 


\section{Cap. 2 - 'A difícil arte de deslizar sobre o mundo' ou 'Montaigne, um político discreto' (De poupar a própria vontade - III, 10)}

A duplicidade do título do presente estudo não é casual. Ela procura refletir os dois planos do ensaio de que nos propomos tratar - um texto simultaneamente ético e político, no qual Montaigne realiza uma crítica das paixões, propõe um modo de regulação das condutas individuais e, ao mesmo tempo, debruça-se sobre o campo da política, empreendendo uma crítica da ambição. Em seu primeiro plano, o propósito do capítulo "De poupar a própria vontade" é ético e seu teor é prescritivo: trata-se de uma crítica das paixões, da recusa da afeição excessiva às coisas, da adesão demasiadamente estreita do sujeito a tudo o que the é alheio e da servidão a que tal adesão conduz. Neste ensaio, Montaigne propõe uma verdadeira ménagerie ${ }^{11}$, mas a casa a ser administrada é o eu. Ele prescreve ao leitor a regulação de seus próprios afetos, de maneira que encontre a justa medida em sua aplicação às coisas e resguarde sua liberdade em relação às mesmas. O quadro (helenístico) é conhecido: trata-se de guardar certa distância em relação às coisas exteriores, a tudo que não está sob o nosso poder, mas sob o poder da Fortuna, podendo ser-nos surrupiado a qualquer momento e sem maiores razões, lançando no

${ }^{11} \mathrm{O}$ título original do ensaio é De mésnager sa volonté. Mésnager é a ação relativa à mesnagerie, a arte da administração doméstica, disciplina que estabelece e executa as regras da gestão da casa (mesnage) e do governo da família e que, na França do século XVI, equivalia à oikonomia dos antigos. O termo é empregado por Montaigne no contexto de uma crítica das paixões. Ele prescreve ao leitor a gestão de seus próprios afetos (o termo vontade é utilizado em um sentido amplo), cuja aplicação sobre os objetos exteriores ele deve regrar, de modo a evitar a afeição excessiva e a intranquilidade e servidão que dela decorrem. 
desespero e no tormento aqueles que não souberam guardar tal distância que não souberam evitar as paixões. Montaigne pretende nos ensinar a difícil arte de "deslizar sobre o mundo" ("glisser le monde"), de evitar "mergulhar muito a fundo nas coisas" ("s'y enfoncer"); pretende nos ensinar a assegurarmos a tranquillitas.

Este, no entanto, é apenas o horizonte mais geral do ensaio, pois a crítica das paixões em "De poupar a própria vontade" realiza-se, sobretudo, num contexto em particular - o da política. Neste texto, Montaigne alerta o leitor para o risco da perda da própria liberdade numa circunstância precisa: a da dedicação à vida pública e às ocupações e cargos políticos. O ensaísta opõe a intranquilidade dos homens que se entregam à vida pública (que se deixam sufocar e arrastar por suas ocupações e cargos) à tranquilidade com que ele próprio desempenhou a função de prefeito $^{12}$ de Bordeaux, como ele o diz: "Consegui misturar-me com os cargos públicos sem afastar-me de mim sequer a distância de uma unha, e dar-me a outrem sem me tirar de mim mesmo" (III, 10, 1007).

Mas, a crítica das paixões tem principalmente um alcance político em "De poupar a própria vontade", pois os afetos comprometem a eficácia e a justiça da ação política, levam os indivíduos a subordinarem o bem comum aos seus interesses privados; cindem a sociedade em seitas e partidos, lançam os cidadãos e as nações nas mais graves disputas. Em "De poupar a própria vontade", Montaigne se debruça sobre a paixão política por excelência: a ambição, o desejo de honras, renome, glória. Acima de tudo, o ensaio faz a

\footnotetext{
${ }^{12}$ Maire, no original. A tradução é aproximada, uma vez que as funções do maire, no tempo de Montaigne, não correspondem exatamente às de um atual prefeito.
} 
crítica desta paixão, pois os homens que se entregam apaixonadamente à vida pública quase sempre o fazem porque visam a projeção pessoal e, com isso, comprometem não apenas a própria liberdade, mas igualmente a liberdade da cidade.

Montaigne foi um político discreto. Foi acusado por detratores de não ter feito nada de marcante enquanto esteve à frente da prefeitura de Bordeaux seus mandatos não teriam deixado vestígios. Em "De poupar a própria vontade", a crítica da ambição permite-lhe responder aos ataques: sua administração discreta foi o feito de um homem que não buscava se projetar, não procurava o destaque diante dos olhos do público, não colocava o interesse privado (o desejo de honras) à frente do bem comum. Também foi obra de um homem que conhece as ilusões da ambição, a intranquilidade e a servidão dos que são movidos por ela. De tal forma que seu mandato à frente da prefeitura de Bordeaux - espécie de conciliação paradigmática entre o cuidado de si e o cumprimento dos deveres políticos - é mais do que um simples dado biográfico, mera curiosidade sobre sua vida: é peça-chave para a compreensão da ética e da política que nos oferece com seus Ensaios.

\section{Crítica da Servidão às Paixões e Prescrição de uma Terapia}

Acompanhemos, então, a trama argumentativa do ensaio. Montaigne começa-o com um curto proêmio, no qual formula a prescrição em torno da qual se constrói todo o capítulo. Ele afirma que devemos evitar os afetos excessivos. Afirma-o, sobretudo, visando uma circunstância específica: a ocupação dos cargos e funções políticas. Tal prescrição visa nos auxiliar a evitar a servidão e a intranquilidade. 
O ensaísta parte do quadro legado pela tradição helenística ${ }^{13}$. Aquele que se apaixona por algo (que experimenta uma afeição ou aversão excessivas) prende-se ao objeto amado ou temido e perde a própria liberdade. Passa a viver em função de tal objeto, ocupando-se dele mesmo quando não está presente, pois seus pensamentos permanecem retidos nele. De tal forma que o apaixonado está sempre fora de si, preso ao objeto da paixão. É uma consciência que não vive o aqui e o agora, que está sempre alhures: no passado, no futuro, noutro lugar. Enfim, é alguém que perdeu o domínio sobre si mesmo (a autarquia), pois seus atos e pensamentos são comandados por aquilo que ama ou teme.

Contra o risco de tal servidão (e ainda de acordo com os ditames da ética antiga), Montaigne propõe uma terapia das paixões. Os termos em que

\footnotetext{
${ }^{13}$ A referência mais imediata do ensaio que ora analisamos é o De tranquillitate animi, texto em que Sêneca formula uma série de prescrições para aquele que deseja assegurar a tranquilidade da alma (a tranquillitas, virtude característica do sábio estóico, estado de alma que acompanha a indiferença às coisas exteriores). Na verdade, todo o ensaio montaigniano parece ser uma espécie de amplificação, realizada no interior do quadro da experiência do autor, da primeira prescrição senequiana: "parcius se inserat officiis" (cf. De tranquillitate animi, IV, 2). Sem dúvida, a crítica da servidão e da perturbação implicadas no páthos é bem mais ampla e antiga, configurando um problema comum a toda a ética clássica (lembremo-nos do Platão do Górgias, que descreve em termos metafóricos o tormento incessante de quem se deixa conduzir pelo desejo, que nunca é saciado: eles são "obrigados a verter em tonéis sem fundo água que trazem com peneiras igualmente incapazes de retê-la”; cf. Górgias, 493c). No entanto, os termos nos quais o problema aparece formulado no ensaio montaigniano remetem mais diretamente às filosofias helenísticas, com especial destaque ao texto de Sêneca que mencionamos, de cuja formulação do problema Montaigne parece partir e cuja resposta, como veremos, parece recusar.
} 
esta se deve dar serão apresentados mais adiante, mas sua prescrição é feita logo no proêmio, por meio de uma contraposição entre o modo de agir do ensaísta, que a aplica, e o dos homens em geral ("le commun des hommes") que se deixam dominar. Montaigne começa dizendo que as coisas o afetam, mas pouco; que ele deseja e teme, mas não a ponto de deixar-se prender. Diz que procura reforçar "pelo estudo e pelo discurso" (III, 10, 1003) esta propensão que reconhece em si mesmo, esforçando-se para restringir a poucas coisas os laços afetivos estreitos ("esposo (...) poucas coisas" - III, 10, idem). Conta-nos, enfim, que dirige seus afetos para si mesmo ${ }^{14}$ e opõe-se com todas as forças às paixões que o prendem alhures. E conclui: "minha opinião é que devemos emprestar-nos a outrem e darmo-nos apenas a nós mesmos" (III, 10, idem).

Este modo de agir vale para a relação com tudo que lhe é alheio ${ }^{15}$. Mas Montaigne imediatamente se volta para um campo determinado: o da relação com outrem. Diz que nas ocasiões em que o solicitaram a cuidar de negócios alheios ("affaires estrangieres") comprometeu-se a encarregar-se deles ("m'en charger"), mas não a entregar-se apaixonadamente à tarefa ("m'en passionner nullement” - III, 10, 1004). Em oposição, então, descreve o comportamento da maioria dos homens, que são servis. Eles comprometem-se a fundo em toda e qualquer tarefa de que se encarregam, sem discriminação de ocasião ou importância ("nas pequenas coisas como nas grandes, no que não lhes toca

\footnotetext{
${ }^{14} \mathrm{O}$ sentido desta conduta, inteiramente conforme, aliás, aos preceitos da ética helenística, será analisado mais adiante.

${ }^{15}$ Um dos pontos mais sensíveis do ensaio - aliás, de todos os Ensaios - é justamente o dos limites entre o eu e o outro. Analisaremos este problema, tal como Montaigne o desenvolve neste ensaio, mais adiante.
} 
como no que lhes toca" - III, 10); são propensos a uma vida servil e intranquila ("tão servis para seus amigos quanto importunos para si mesmos" - III, 10). Contrário a esta conduta, o ensaísta recomenda a discriminação das ocasiões e assuntos que realmente exigem um comprometimento maior - um discernimento que deve comandar o trabalho sobre os afetos.

\section{Circunscrição ao Campo Político. A Justa Medida do Amor de Si.}

Imediatamente, então, Montaigne passa para o campo da política, relatando as circunstâncias em que assumiu a prefeitura de Bordeaux. Contanos que disse aos que lhe impuseram o cargo que não comprometeria a própria liberdade com uma aplicação excessiva à nova ocupação, como fizera seu pai quando, anos antes, conduzira a cidade. A dedicação desmedida de Pierre Eyquem aos assuntos públicos, no entanto, não configura um vício aos olhos do ensaísta, posto que visava o interesse coletivo, não a projeção pessoal ("jamais houve alma mais caridosa e popular” - III, 10, 1006), não sendo pautada por uma intenção pervertida. Apesar disso, não deixa de lhe parecer um comportamento a ser evitado - até porque se apoia numa opinião que considera falsa: aquela segundo a qual a coletividade vale mais e tem precedência sobre o indivíduo, que deve se sacrificar em seu nome. Recorrendo, então, à justa medida do amor de si, Montaigne refuta o preceito que teria pautado o modo de agir de seu pai, mostrando que o indivíduo, ao contrário do que Pierre Eyquem pensava, deve alguma atenção a si mesmo: "Quem conhece seus deveres descobre em seu papel que deve aplicar a seu favor o uso dos outros homens e do mundo, e, para fazê-lo, contribuir para a sociedade pública com os deveres e ofícios que lhe tocam" (III, 10, idem). 
Numa única e mesma frase, o ensaísta formula as duas exigências que devem ser satisfeitas: a do indivíduo (aplicar os outros a seu favor) e a da coletividade (aplicar-se em favor dos outros).

Tudo se passa, no entanto, como se tal equilíbrio fosse o meio do caminho entre dois polos contraditórios: devo me dedicar um pouco menos à cidade para me preservar; devo me dedicar um pouco menos a mim mesmo, pois tenho deveres em relação à coletividade. Seria como se as exigências pessoais e as da cidade se opusessem e o indivíduo tivesse de temperar uma com a outra. Ora, não é este o sentido da justa medida proposta por Montaigne, pois imediatamente ele afirma que não prescreve uma dedicação menor às tarefas políticas ("não quero que recusemos aos cargos que tomamos a atenção, os passos, as palavras, nem o suor e o sangue se for preciso" - III, 10, 1007), apenas recusa a presença da paixão em seu exercício ("não sem ação, mas sem vexação" - idem). Este é o elemento a ser combatido. Por meio deste combate, o indivíduo atenderá às suas próprias prerrogativas (assegurará sua liberdade e tranquilidade) e, ao mesmo tempo e igualmente, atenderá às prerrogativas da cidade, que será beneficiada por uma ação política mais eficaz e mais justa, porque não apaixonada. Inversamente (poderíamos imaginar), o indivíduo que se entrega apaixonadamente às ocupações políticas sacrifica a si mesmo bem como a cidade - compromete sua própria liberdade e a condução dos assuntos públicos. De tal forma que não há tensão, mas convergência entre os interesses da cidade e os do indivíduo: o bem de um implica o bem do outro, como o mal de um, o mal do outro. Neste ponto, Montaigne permanece estreitamente alinhado com os antigos. 


\section{Afastar a Paixão em nome da Ação. Montaigne Agente.}

Busquemos compreender melhor a segunda parte do problema - isto é, de que maneira a entrega apaixonada do indivíduo às funções públicas compromete os interesses da cidade. Montaigne se ocupa desta questão em um novo movimento argumentativo do ensaio, no qual distingue a ação da paixão e aponta o erro dos que veem 'mais ação' no envolvimento apaixonado com determinada atividade e 'menos ação' numa relação fria e desinteressada. Ocorre, diz o ensaísta, justamente o contrário: a paixão reduz o espaço da ação, consome as forças do agente e obscurece seu raciocínio, mergulha-o na ansiedade e na desordem de espírito, apressa o andamento das coisas e impede a calma consideração das circunstâncias ("esta aspereza e violência de desejo mais impede do que serve à condução do que empreendemos" - III, 10, 1007). Ação e paixão, diz Montaigne, são mutuamente excludentes ("uma vai bem sem a outra" - idem), como comprova a experiência. Afinal, vê-se frequentemente um desempenho melhor naqueles que mantêm uma relação desinteressada com a atividade, enquanto se constata a inércia de homens profundamente preocupados com os mesmos eventos ("têm a alma mais absorvida [pela guerra] do que o soldado que nela emprega seu sangue e sua vida" - idem). A paixão, enfim, não leva à ação e ainda a atrapalha, pois a preocupação excessiva com os resultados da ação (a expectativa de que o fim seja alcançado) prejudica o bom andamento dos meios: "Aquele que se porta mais moderadamente em relação à vitória e à derrota está sempre em si mesmo; quanto menos aguilhoa-se e apaixona-se pelo jogo, com tanto mais vantagem e segurança o conduz" (III, 10, 1009). Daí o erro dos que se entregam apaixonadamente à vida pública. Eles comprometem a eficácia e a 
justiça de suas ações, que só podem advir de uma fria ponderação. Daí a recomendação montaigniana para que se coloque em prática uma terapia dos desejos e das aspirações que corrija nossa relação com os fins.

\section{Economia dos Desejos e Aspirações. Os Costumes como Medida.}

Um novo movimento do ensaio, então, dedica-se a formular esta terapia. Toda uma tradição já denunciara os mecanismos perversos da paixão, que põem o sujeito num movimento perpétuo, numa busca sem fim, em que cada objeto alcançado imediatamente perde o brilho diante de outro que chama atenção à distância - movimento acompanhado de insatisfação e ansiedade permanentes. Montaigne segue de perto esta tradição, assimila sua crítica das paixões e até mesmo parece adotar a terapia que ela propõe - mas altera significativamente seus termos. Vejamos a passagem em que começa a apresentar sua própria versão da terapêutica dos afetos:

"De resto, impedimos a captura e a retenção pela alma ao Ihe darmos tantas coisas para agarrar. Algumas, devemos apenas apresentar-Ihe; outras, atar; outras, incorporar. Ela pode ver e sentir todas as coisas, mas deve alimentar-se apenas de si, e deve ser instruída quanto ao que Ihe concerne propriamente, e que propriamente faz parte de seus haveres e de sua substância. As leis da natureza nos ensinam o que exatamente nos é necessário. (...) os sábios (...) distinguem sutilmente os desejos que provêm dela daqueles que provêm do desregramento de nossa imaginação" (III, 10, 1009; grifos nossos) 
Montaigne, como se vê, prescreve diferentes tipos de relação e níveis de afetividade ('ver e sentir', 'atar a si', 'incorporar a si', 'alimentar-se') conforme os diferentes objetos, recomendando que evitemos afeiçoar-nos em excesso ('incorporar a si', 'alimentar-se') ou que no-lo permitamos somente em relação a poucas coisas: àquelas que nos concernem, que fazem parte dos nossos haveres e substância. Segundo certa tradição ('os sábios'), trata-se dos objetos das nossas necessidades naturais (comer, beber etc.), aqueles pelos quais garantimos a conservação da nossa própria vida. Eles são "nossos haveres e substância" porque por meio deles (isto é, à medida que os buscamos) agimos com vistas à nossa preservação, à realização da nossa própria natureza; de tal forma que, quando os buscamos, visamo-nos, buscamo-nos. Todo excesso de afetividade por outros objetos que não os de nossas necessidades naturais (por exemplo, a honra ou a riqueza) é fonte de servidão e intranquilidade, pois é afeição por um outro sobre o qual não temos poder, e que pode ser-nos subtraído a qualquer momento pela Fortuna. Inversamente, quando buscamos apenas a satisfação das nossas necessidades naturais, desligamo-nos do outro e recuperamos a autarquia e a tranquilidade. ${ }^{16}$

${ }^{16} \mathrm{O}$ quadro de referências teóricas por detrás desta passagem é dado, sobretudo, pelos estóicos e pelos cínicos. Trata-se, em linhas muito gerais, da defesa da indiferença em relação às coisas exteriores e da busca, única e exclusiva, da satisfação das necessidades naturais e, por aí, da oikeiosis - o habitar-se a si mesmo, querer-se como a natureza o quer. Montaigne parece se aproximar do estoicismo pela maneira como concebe a indiferença, pois ele não prescreve que deixemos de buscar as coisas exteriores, apenas que evitemos a paixão (assim como os estóicos qualificavam as coisas exteriores de indiferentes, mas preferíveis). Por outro lado, como veremos a seguir, afastar-se-á da regra de conduta cínica: a da restrição dos desejos à satisfação das necessidades naturais. 
Ocorre que Montaigne, quando se volta para si mesmo e se examina, não encontra a natureza operando, mas somente os costumes que o determinam e constituem ("o que falta para o meu costume considero que me falta" - III, 10, 1010, grifos nossos). Assim, quando se permite apaixonar-se somente pelos objetos que concernem e pertencem ao eu (por aquilo, enfim, que não é outro), ele não restringe as paixões aos objetos das necessidades naturais, mas aos dos costumes do seu país, da sua cidade, da sua classe, da sua família ("taxemo-nos, tratemo-nos de acordo com esta medida, estendamos até lá nossos pertences e nossas contas" - III, 10, 1009). A medida dos afetos, pois, não é a da natureza, mas a do costume. De resto, Montaigne acrescenta que se trata de uma medida mais ampla e generosa (mais de acordo com o homem comum, que não é sábio) do que a prescrita pela tradição supracitada. Nem por isso, no entanto, deve ser obedecida com menos rigor: "é a maior extensão que podemos outorgar aos nossos direitos. Quanto mais amplificamos nossas necessidades e nossa posse, tanto mais nos comprometemos com os golpes da fortuna e das adversidades" (III, 10, 1011).

\section{A Política como Teatro. Recusa do Partidarismo sem Crítica.}

Interessa principalmente realizar esta terapia dos afetos no contexto político. Na sequência imediata do texto, então, Montaigne insiste que devemos nos aplicar às nossas funções, mas não sem deixar de nos distinguir das mesmas - de separar a pessoa do cargo ocupado, o eu da função desempenhada: "É preciso representar devidamente nosso papel, mas como papel de um personagem emprestado" (III, 10, idem). Sem avançar sobre o problema do estatuto do eu e dos contornos que o determinam, o ensaísta 
prescreve certo distanciamento do sujeito em relação às funções que desempenha, as quais devem ser exercidas segundo o modelo da representação teatral. Ele recomenda o recuo crítico que permite ao ator aplicar-se integralmente à execução do papel e, ao mesmo tempo, assegurar a integridade do eu: "da máscara e da aparência não devemos fazer uma essência real, nem do alheio o próprio" (idem). Sem investigar o problema da alienação, que ocupará as reflexões de pensadores posteriores, Montaigne parece chegar às suas portas, conduzido pelo problema da servidão. Aqui, o risco a ser combatido é o da perda da própria liberdade, do domínio sobre si mesmo, em função da afeição excessiva aos cargos e funções. O autor se apresenta, enfim, como modelo na prevenção deste risco: "o prefeito e Montaigne sempre foram dois, por uma separação bem clara" (III, 10, 1012).

Não se trata, no entanto, de uma defesa do uso da máscara - do ocultamento e da dissimulação, da manipulação do outro no espaço público em favor de seus próprios interesses privados. Trata-se, justamente ao contrário, de demarcar com clareza as fronteiras do público e do privado, de prescrever para o homem privado um recuo crítico em relação aos cargos que ocupa, que Ihe permita atender aos seus interesses privados (assegurar sua liberdade e tranquilidade) e ao mesmo tempo buscar o interesse público - o bem comum. $\bigcirc$ ambicioso, que se afeiçoa vaidosamente aos cargos que ocupa, busca no exercício da vida pública a realização de fins privados - procura a satisfação pessoal nas honras que conquista como homem público. Ao fazê-lo, contudo, compromete tanto a sua satisfação pessoal (pois permanece intranquilo, sempre em busca de mais honras e com medo de perder as que já conquistou) quanto o interesse público, que ele mantém subordinado aos seus interesses 
privados. Ao combater a afeição pelos cargos (ao distinguir-se dos papéis que ocupa), ele pode finalmente encontrar a tranquilidade que a busca da honra não Ihe trazia, ao mesmo tempo em que passa a poder buscar, no exercício dos cargos, o fim próprio da vida pública - o bem comum.

O mesmo movimento é realizado por Montaigne quando examina a relação do indivíduo com o partido a que pertence - no caso, o partido religioso. Em nenhum momento o ensaísta recusa a adesão convicta a um grupo, nem mesmo a certeza de que se trata da melhor das posições ("eu me agarro firmemente ao mais são dos partidos" - III, 10, 1013), mas recusa a adesão sem crítica, a incapacidade para discriminar os erros dos aliados e reconhecer os acertos dos adversários - a conduta, enfim, da maioria dos homens, tão contrária ao seu modo de agir: "quando minha vontade entregame a um partido, não é com uma obrigação tão violenta que infecte meu entendimento. (...) Eles adoram tudo o que está do seu lado: eu nem sequer desculpo a maior parte das coisas que vejo do meu" (III, 10, 1012). A maioria dos homens adere integralmente a um dos lados, daí a incompreensão que sofreram as opiniões do ensaísta: "Ele é da Liga, pois admira a graça do Senhor de Guise. A atividade do Rei de Navarra maravilha-o: ele é huguenote." (III, 10, 1013)

Ora, os indivíduos são incapazes de criticar o partido a que pertencem porque a crítica também os afetaria, uma vez que, apaixonados, não se distinguem do grupo. Eis porque se encolerizam quando outros o atacam: defendem-se a si próprios, quando defendem o partido. Mas qual é exatamente o objeto da paixão que os arrasta? A causa do partido, que creem representar melhor o bem da coletividade? Poderíamos até admitir que a crítica de 
Montaigne atinja lateralmente este 'apaixonado bem intencionado' (como de alguma forma parecia atingir, no começo do ensaio, o engajamento apaixonado de seu pai), mas ela visa, antes de tudo, outra figura: o indivíduo que não critica o grupo porque tem interesses pessoais vinculados a ele, tendo a ganhar com sua vitória e a perder com sua derrota ("eles não se interessam pela causa comum, enquanto ela fere o interesse de todos e do estado, mas somente enquanto os machuca privadamente. Eis porque são aguilhoados por ela em função de paixão particular e para além da justiça e da razão pública." - III, 10, 1012). Interesses privados são o objeto de sua paixão, à qual Montaigne se opõe francamente: "meu interesse não me fez desconhecer nem as qualidades louváveis em nossos adversários, nem aquelas que são repreensíveis naqueles que segui” (III, 10, 1013).

Uma terapia das paixões, enfim, é a condição do recuo crítico em relação ao partido. Quem ganha com isso é o interesse geral. Ganha também o indivíduo, que não mais se perturba diante das derrotas do grupo. Ganha, enfim, o próprio partido: "prejudicamos os partidos justos quando queremos socorrê-los [a todo custo]. Sempre me opus a isto. Tal expediente só ocorre às cabeças doentes; para as saudáveis, há vias mais seguras e não somente mais honestas para manter a moral e aliviar os acidentes contrários" (III, 10, 1014). 


\section{A Terapia das Paixões. O Momento Oportuno. Diversão versus Patientia.}

É necessário, pois, avançar na definição dos preceitos de uma terapia das paixões. Montaigne começara a fazê-lo algumas páginas atrás. Agora, aprofundar-se-á na tarefa. Ele começa lembrando que certos sábios da antiguidade não precisavam se preocupar com os afetos excessivos: eram fortes o bastante para se apaixonar e suportar tranquilamente a perda do objeto amado ("não temeram apegar-se e comprometer-se até o âmago com várias coisas" - III, 10, 1015). Sua força Ihes permitia enfrentar as turbulências das paixões sem prejuízo para a própria tranquilidade ("estas pessoas estão seguras de sua força, sob a qual se protegem de todo tipo de acontecimento adverso, fazendo os males lutarem em função do vigor da resistência" - idem). O ensaísta acrescenta que tais sábios, no entanto, não servem de modelo para a maioria dos homens (dentre os quais o próprio Montaigne se coloca), que são homens ordinários, não possuindo a força de um Catão ("não nos lancemos atrás destes exemplos; não os alcançaríamos" - idem). Em seu lugar, propõe o exemplo de outras figuras (Sócrates, Zenão e Ciro) que preferiam evitar o avanço dos afetos em vez de suportar os seus excessos. Montaigne traça, assim, uma oposição entre o enfrentamento que supõe a força (a enkrateia ou patientia) e uma estratégia que consiste em evitar o avanço dos afetos, lidando com eles enquanto ainda são incipientes. Os impulsos afetivos, neste contexto, são compreendidos segundo uma metáfora biológica - 'nascem' e 'crescem', ganhando corpo. O homem comum, incapaz de suportar a tormenta, deve atuar sobre seus afetos enquanto ainda são frágeis, aproveitar o momento oportuno e agir assim que se despertam ou, de preferência, antes, quando prevê seu 
despertar ("sinto a tempo os ventinhos que me vêm roçar e sussurrar por dentro, precursores da tempestade" - III, 10, 1017).

Que gênero de ação Montaigne prescreve? Resistir às primeiras manifestações afetivas, fazendo frente aos objetos que inspiram medo ou desejo? Não. Talvez por desconfiar demais de suas forças ou da possibilidade de agir sobre os próprios afetos, o autor nunca propõe um embate ou ação direta sobre eles, nem mesmo enquanto incipientes. Em vez disso, a estratégia é a do desvio, da fuga; a terapia consiste em evitar o enfrentamento: "Sócrates não diz: - Não vos rendais aos atrativos da beleza, fazei frente a ela, esforçaivos contra ela! Ele diz: - Fugi dela!" (III, 10, 1015). Trata-se de evitar as circunstâncias e situações em que, por experiência, sabemos que nossos afetos tendem a se tornar excessivos; trata-se de evitar, enfim, a presença dos objetos ou imagens (pensamentos, lembranças) que os alimentam e intensificam: "outrora, eu gostava dos jogos de azar (...) desfiz-me deles há muito tempo, apenas porque, por mais que fizesse uma cara boa ao perder, não deixava de me sentir aguilhoado por dentro" (III, 10, 1015). E quando o encontro não puder ser evitado, que se busque o pronto afastamento da consciência, seu desvio (divertissement) para outros objetos ou representações: "Zenão, vendo aproximar-se Cremônides, jovem que ele amava, para sentar-se perto dele, levantou-se subitamente" (idem). De maneira semelhante, Montaigne constrói o discurso consolatório da famosa passagem do ensaio "Da experiência", procurando substituir a imagem assustadora de sua doença por uma representação mais favorável: "trato minha imaginação o mais suavemente que posso (...) Meu espírito é próprio para este serviço: (...) diz que é para o meu bem que eu tenho cálculos" (III,13, 1090). Incapaz de 
poder atuar sobre os próprios afetos, o homem comum deve agir sobre as representações que os mobilizam ${ }^{17}$.

A terapia que Montaigne prescreve, assim, aplica-se a um certo tipo de homem, que constitui uma generalidade com a qual o autor se identifica: é o homem comum, imperfeito, fraco, o não-sábio. Embora descrita de diferentes formas, conforme os pressupostos de cada escola, tal figura esteve presente em todas as doutrinas éticas da antiguidade, como contraponto à figura do sábio. Por diversas vezes, a confissão que Montaigne faz da própria fraqueza, em inúmeras passagens dos Ensaios, foi considerada pelos comentadores um sinal da recusa montaigniana da possibilidade de um projeto ético. Montaigne assinalaria a falibilidade incontornável do homem e recusaria, de uma vez por todas, a possibilidade dele tornar-se sábio e, assim, realizar a virtude. No lugar de uma ética, então, restaria um acordo permanentemente tenso entre as exigências egoístas do próprio indivíduo (que se sabe incontornavelmente falível e que não deve se arrepender por seus próprios erros) e as imposições

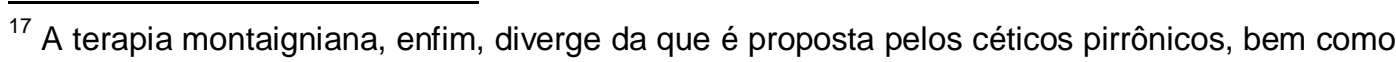
das terapias estóica e epicurista, pois não se trata de procurar uma representação antitética para opor a uma primeira phantasía e, com isso, obter a isostheneia e a ataraxia - como no caso dos pirrônicos. Nem de substituir uma interpretação falsa sobre uma representação (p. ex., 'a morte é temível') por uma supostamente verdadeira ('a morte não é temível'), como no caso dos estóicos e epicuristas. Montaigne propõe o desvio da consciência de uma representação que provoca uma paixão (dor, tristeza, medo, cólera etc.), para uma outra que restitua a tranquilidade da alma, pouco importando seu conteúdo e, sobretudo, sua verdade ou falsidade. Vale, até mesmo, uma construção discursiva de cujo conteúdo a própria consciência desconfia. Ela sabe da precariedade da terapia ("se [meu espírito] persuadisse como prega, socorrer-me-ia com sucesso" - III, 13, p. 1090), mas a toma como o único recurso possível (“amanhã, providenciaremos outras escapatórias" - Idem, p. 1095).
} 
e normas da sociedade, que o indivíduo deve respeitar em seu próprio interesse, uma vez que, fraco, depende da vida em sociedade. Esta, por exemplo, é a leitura que faz Hugo Friedrich ${ }^{18}$, que deriva da declaração de falibilidade feita por Montaigne uma moral com traços pragmáticos. Ocorre, no entanto, que a confissão de fraqueza feita pelo ensaísta não parece retirá-lo da busca do aperfeiçoamento. Isto é evidente num ensaio como "De poupar a própria vontade", que se abre com as seguintes palavras: "Tenho grande zelo em aumentar por estudo e por discurso este privilégio de insensibilidade que em mim é naturalmente bem avançado." (III, 10, 1003). A declaração montaigniana da própria falibilidade, pois, não parece incompatível com a perspectiva de algum aperfeiçoamento (de alguma melhoria de seu próprio estado), ainda que a realização de um ideal de homem acabado, perfeito (o sábio) pareça afastada. A percepção da própria fraqueza, enfim, apenas leva o autor à adoção de uma outra terapia, de uma outra forma de evitar as paixões, diferente daquela adotada pelo sábio. Sêneca já dizia o mesmo num texto como o "De constantia sapientis": "Mas, o sábio e o aspirante à sabedoria usarão de remédios diferentes. (...) Vós, vós estais em plena ação; para ele, a vitória é coisa adquirida." ${ }^{\text {"S }}$. Sem dúvida, as prescrições montaignianas devem ser sempre singularizadas, o leitor dos Ensaios deve fazer a experiência de si e verificar se é ou não sábio, devendo, a partir daí, escolher a terapia que lhe é mais adequada. De qualquer forma, dirigindo-se ao homem comum, fraco, imperfeito, Montaigne se volta para a quase totalidade dos homens, de forma

\footnotetext{
${ }^{18}$ Cf. Montaigne, pps. 194-209, 240-1.

${ }^{19}$ De constantia sapientis, (XIX, 4-5)
} 
que as suas prescrições têm um alcance muito mais geral do que se poderia suspeitar.

\section{Origem vã das disputas e desfechos vergonhosos: paixão no começo e no fim}

Montaigne insiste na facilidade desta ménagerie: "com pouquíssimo esforço eu detenho este primeiro abalo [branle] de minhas emoções, e abandono o assunto que começa a me pesar, e antes que me arrebate" (III, 10, 1017). Insiste, ainda, na facilidade com que lidaríamos com as frustrações e perdas se diminuíssemos as expectativas, se evitássemos os afetos excessivos: "um quarto de onça de paciência nos provê contra tais inconvenientes” (idem, 1016). Quanta intranquilidade poderia ser evitada se agíssemos no momento oportuno sobre os nossos afetos! E quantas disputas entre homens, povos e nações! Com uma nova inflexão argumentativa, Montaigne aponta a motivação vã da maioria das disputas entre indivíduos, partidos e nações: contendas e guerras que se alimentam de paixões inflamadas e que poderiam ser evitadas se os afetos fossem abrandados. Aqui, Montaigne chega à expressão última das consequências da paixão: a ruptura dos laços com o outro, o lítigio entre indivíduos e, mais gravemente, a guerra entre partidos e povos. Assim, a rigorosa estrutura argumentativa que subjaz o movimento fluido do ensaio alcança o seu fim. Pois, Montaigne inicia seu texto com a prescrição da moderação das paixões, distingue-as das ações, propõe a limitação dos desejos, faz a crítica da alienação, apresenta a terapia que devemos seguir e, finalmente, chega ao ponto a que é conduzido aquele que 
não pôs em prática a ménagerie: a perturbação, a turbulência, que se dão nos planos interno (a luta do indivíduo contra as próprias paixões, ou contra si mesmo) e externo (as querelas, a guerra). Em ambos os casos, o momento oportuno apresenta-se logo no início: aí, a ação é fácil; mas, depois que as paixões se inflamaram, fazem-se necessárias grandes providências. ${ }^{20}$

Montaigne arrola uma série de exemplos para mostrar que a maioria de nossas disputas começa por motivos vãos, passíveis de fácil esclarecimento. Ele recorda as maiores guerras e contendas da história - disputas que dividiram o mundo e levaram ao colapso as mais brilhantes formas de governo - para mostrar que, mesmo estas, começaram por causas vãs: "e a gravação de um selo, não foi a primeira e principal causa do mais horrível abalo que esta máquina jamais sofreu? Pois Pompeu e César são apenas os rebentos e a consequência dos dois outros" ${ }^{21}$ (idem, 1018). A lição que o ensaísta extrai dos exemplos é clara: devemos agir sobre as causas da contenda antes que as paixões entrem em cena - no momento em que ainda é possível a calma consideração do ponto em divergência: "na entrada [a l'enfourner], é preciso apenas um pouco de aviso; mas, uma vez que vós embarcastes, todas as cordas se retesam" (idem). Assim, toda uma série de disputas inúteis e guerras

\footnotetext{
${ }^{20}$ Aqui, o moralista dá lugar ao juiz e ao diplomata - afinal, quantas querelas entre indivíduos e partidos Montaigne não foi chamado a dirimir? Neste movimento do texto, o ensaísta faz uma espécie de radiografia dos litígios e processos diplomáticos, nos quais as paixões tem um peso significativo. A maneira pela qual intervem e o tipo de ação que solicitam obedecem ao modelo descrito no movimento anterior: uma crescente intensificação que pede uma ação preventiva. 21
} 
vãs poderiam ser evitadas: "quão mais fácil é não entrar nisso do que sair?" (idem).

Mas, a crítica de Montaigne não se limita a apontar a origem vã de nossas guerras e disputas - ela insiste, ainda, sobre seu desfecho frequentemente vergonhoso ("a maior parte dos acordos de nossas querelas de hoje são vergonhosos e mentirosos" - idem, 1019). Pois, se elas começam com a falta de senso dos homens, que se inflamam por tolices e lançam-se em contendas irrefletidamente ("se mettent inconsideréement et furieusement en lice" - idem, 1019), elas terminam, as mais das vezes, com gestos de covardia - recuos, desmentidos, retratações pusilânimes. Montaigne descreve o comportamento típico dos homens que se lançam irrefletidamente às querelas: inflamam-se no início, lançando-se com fúria à contenda; mas, logo, sua força esmorece, seu ímpeto diminui - diante do adversário, recuam, desmentem-se, e buscam pôr fim à contenda por meio de acordos baseados na mentira e na covardia: "nós sabemos como nós o dissemos e em que sentido (...) é às expensas de nossa franqueza e da honra de nossa coragem que renegamos nosso pensamento e procuramos refúgios na falsidade para entrarmos em acordo." (idem, 1019)

Trata-se, de fato, da descrição de um tipo: pois é assim que o homem apaixonado entra nas querelas mais desnecessárias, e assim que, delas, sai. $\mathrm{O}$ processo que ele obedece segue uma lógica quase necessária: ao lançar-se impetuosamente às contendas, ele dispende suas energias logo de início, recaindo, inexoravelmente, na falta de ânimo e na fraqueza. Neste quadro, o vício da temeridade implica necessariamente no seu extremo oposto - a 
covardia. O apaixonado, assim, oscila entre os extremos viciosos, justamente porque não soube regular sua vontade, preservando suas energias do começo ao fim do processo. Por espelhamento, então, podemos inferir o comportamento do virtuoso, que busca de maneira calma e tranquila a solução da desavença, entrando em disputas somente em último caso, quando esgotadas as alternativas legítimas de evitá-las. Ele não entra em contendas, portanto, movido pelos afetos. Assim, preserva suas energias - que não são consumidas pelas paixões - e permanece forte ao longo de todo o litígio, não sendo levado, por fraqueza e desânimo, aos recuos, desmentidos e à busca de um acordo vil. Montaigne emprega uma imagem botânica para ilustrar, pelo avesso, esta virtude - a constantia: "devemos proceder ao contrário do caniço, que produz uma haste longa e reta quando brota; mas depois, como se estivesse enfraquecido e sem fôlego, começa a fazer nós frequentes e espessos, como pausas, que mostram que ele não tem mais o primeiro vigor e constância" (idem, 1018).

\section{Prestação de Contas e Crítica da Ambição: o Tato Político de Montaigne}

Chegamos, enfim, à conclusão do ensaio - fim que bem poderia servir de começo para o comentário. Pois, Montaigne conclui "De poupar a própria vontade" com uma prestação de $\operatorname{contas}^{22}$ de seu mandato à frente da prefeitura

\footnotetext{
${ }^{22}$ Sobre este ponto, Géralde Nakam (Les Essais, Miroir et Procès de leur Temps, p. 445-51) propõe uma leitura bastante interessante, interpretando o ensaio segundo o "modelo das provas a que era submetido o magistrado ateniense": dokimasia (exame prévio ao exercício da função), epikheirotonia (voto de confiança a que era submetido durante o exercício, que
} 
de Bordeaux. Ora, todo o capítulo pode ser compreendido como uma grande justificação do seu modo de agir quando ocupou este posto - empresa que lhe teria dado o ensejo para uma crítica das paixões, em geral, e da ambição, em particular. Na conclusão, então, Montaigne elenca as duas críticas que foram feitas aos seus mandatos. A primeira: não teria se aplicado o bastante em suas funções de prefeito, mas "como homem que se move por demais frouxamente e com uma vontade débil" (III, 10, 1020). Ao que ele responde: os que me dirigem esta crítica "não estão de modo nenhum distantes da verdade", pois "eu tento manter minha alma e meus pensamentos em repouso" (idem). Mais uma vez, o ensaísta mostra ter agido de acordo com a exigência ético-política da serenidade (a tranquillitas), de tal forma que a dosagem de sua aplicação não deve ser confundida com incapacidade ("pois falta de preocupação e falta de senso são duas coisas diferentes") ou falta de empenho ("mobilizei-me [pelo povo] como o faço por mim").

O ponto culminante do ensaio, no entanto, vem com a resposta dada por Montaigne à segunda crítica que lhe dirigem. Ele afirma que alguns o criticam por não ter feito nada de marcante durante seu mandato - nada que tivesse permanecido na memória de seus concidadãos: "dizem também que esse meu

poderia ser suspenso caso se averiguasse não ter o magistrado cumprido bem seus deveres), logistai kai euthunai (prestação de contas ao expirar o exercício do cargo). Cada uma dessas "provas" é rastreada pela comentadora em De poupar a própria vontade: o discurso em presença dos jurats ("A mon arrivée, je me deschiffray fidelement et conscientieusement..." - III, 10 , p. 1005) cumpre as vezes da primeira, ou seja, constitui sua dokimasia; a reeleição para o segundo mandato ("C'est une charge qui (...) peut estre continuée par seconde election (...) Elle le fut à moy" - idem, ibidem), a da segunda, ou seja, sua epikheirotonia; sendo o corpo todo do ensaio considerado como a prestação final de contas, sua euthunai. 
mandato passou sem deixar marca nem vestígio" (III, 10, 1021). Contra esta crítica, o ensaísta afirma que não deixou de lado nenhuma iniciativa que o dever tenha exigido ("aucun mouvement que le devoir requist en bon escient de moy"); que não levou adiante apenas as prescritas pela ambição ("ceux que l'ambition mesle au devoir et couvre de son titre" - idem). Diz ter desempenhado todas as tarefas que sua função de prefeito Ihe impunha, mas não ter buscado se destacar aos olhos do povo. Se pôde cumprir seu dever "à noite, na Câmara do Conselho", assim o fez - não deixou para desempenhar suas tarefas "ao meio-dia, na praça pública". Montaigne sabe que os homens só se contentam com a visão das ações, que precisam vê-las em curso; do contrário, pensam que nada foi feito ("se não ouvem barulho, parece-lhes que estamos dormindo" - idem). Mas fez prevalecer um outro critério sobre o desejo de projeção pessoal: o dever. Assim, agiu de maneira diferente da maioria dos homens, que "[buscam] sua reputação e proveito particular, não o bem", como aqueles cirurgiões da Antiguidade, "que faziam as operações de sua arte sobre estrados à vista dos passantes, para adquirir (...) freguesia." (III, $10,1022)$

Tais considerações lhe dão o ensejo para uma crítica direta da ambição, empreendida por meio de dois argumentos. No primeiro, sustenta que ela não convém à maioria dos homens (entre os quais o próprio ensaísta se coloca), que são comuns, incapazes de ações dignas de glória e que, esperando granjear louvores por meio de ações corriqueiras, mostram tanto mais sua própria mediocridade ("eles querem atribuir-lhe o preço que ela[s] Ihes custa[m]" - III, 10, 1023). No segundo, sustenta que a ambição é contraproducente, que a busca da honra só conduz à desonra, posto que 
implica numa postura servil ("Desdenhemos essa sede de fama e de honras, baixa e suplicante, que nos faz mendigá-las a toda espécie de pessoas (...), por meios abjetos e pelo preço vil que for. É desonra receber honras assim."idem). Louvável é a ação livre, cujo fim encontra-se nela mesma, no seu valor intrínseco. Aquela que se executa como meio para a projeção pessoal é feia e repreensível. Ora, os motivos que levam o agente às ações de destaque são sempre dignos de suspeita: "Na medida em que uma boa ação é mais ruidosa, vou descontando de seu valor a suspeita que começo a ter de que seja praticada mais por ser ruidosa do que por ser boa" (III, 10, 1023). A passagem se encerra, então, com o elogio da ação discreta: "Muito mais mérito têm as ações que escorregam da mão do autor despreocupadamente e sem alarde, e que depois algum homem de bem nota e resgata da sombra, impelindo-as para a luz por causa de si mesmas." - idem)

Terminada a crítica da ambição, Montaigne retorna à refutação de seus críticos, insistindo que agiu de acordo com as circunstâncias e visando unicamente o cumprimento de seu dever. Afinal, eram tempos de crise, uma época em que o tecido social do país, já tão esgarçado pelas guerras de religião, ameaçava romper-se em definitivo; um período, pois, em que intervenções incisivas (inovações) não eram recomendáveis, posto que agravariam ainda mais o quadro de crise (iniciado, aliás, por uma primeira inovação: a Reforma). Neste contexto, convinha ao político manter certa distância dos eventos, conduzir-se com delicadeza nas situações, observar e aguardar que os tumultos arrefecessem, intervindo somente quando necessário. Seguindo o modelo de uma medicina empírica, Montaigne se propôs a observar as evoluções da 'doença' que acometia a cidade e a deixá- 
la, tanto quanto possível, seguir seu curso natural em direção ao arrefecimento - sabendo que, as mais das vezes, o remédio prejudica mais o corpo do que a doença. Esta ação cautelosa, enfim, visava conservar e prolongar (fazer durar) a ordem frágil que ainda subsistia no corpo social, esperando que o tempo e o arrefecimento dos ânimos lhe permitissem recuperar o vigor original. Ocorre que tal ação (a ação de conservação) é silenciosa e imperceptível - apenas a inovação salta aos olhos. Seu senso de conveniência e sua profunda compreensão de seu tempo, portanto, forneceram a Montaigne os motivos para se manter à sombra.

\section{Uma Ambição Morna e Discreta}

Terminada a leitura do ensaio, acreditamos ter dado alguma clareza à atuação política de Montaigne ou, mais precisamente, à sua posição a respeito das paixões (sobretudo, da ambição) no contexto político. Como vimos desde o proêmio do capítulo, o ensaísta se esforça para afastar a ambição do horizonte da política, seja pelo risco que ela representa para a liberdade e a tranquilidade do indivíduo, seja porque os interesses públicos devem permanecer à frente dos interesses privados. De resto, a ambição não convém ao homem medíocre, figura que representa a maioria dos homens e na qual Montaigne se reconhece. De tal forma que, ainda que admitíssemos a existência de uma ambição montaigniana, ela não poderia ser senão objeto da terapia das paixões proposta pelo ensaísta. Lembremo-nos de suas palavras ainda no proêmio do ensaio: "Mas, às paixões que me distraem de mim e me prendem alhures, a essas certamente me oponho com todas as minhas forças". (III, 10, 1003) 
Poderíamos, no entanto, desconfiar das razões alegadas pelo autor e suspeitar da aparente assepsia de sua atuação política, tal como a descreve no "De poupar a própria vontade". Poderíamos nos perguntar se Montaigne não é pouco sincero quando leva tão longe a crítica das paixões e se não oculta, por trás do que diz, alguma ambição. Afinal, todo o ensaio é uma defesa de sua atuação política, na qual ele parece exibir-se discretamente como um político zeloso, atento ao dever e às circunstâncias históricas. O texto, sem dúvida, parece ter esta intenção. Deveríamos inferir daí, então, uma ambição montaigniana? Como ela seria possível depois de um ataque tão longo e profundo às paixões? Como conciliar a trama argumentativa do ensaio com o efeito que, ao final, ele parece produzir no leitor (uma admiração imediata por um político tão zeloso e atento ao bem comum)?

Para responder a esta questão, devemos lembrar que a terapia montaigniana das paixões não tem como alvo a afetividade enquanto tal. Como vimos, o ensaísta prescreve uma economia dos afetos que visa evitar os excessos, dando lugar aos impulsos moderados. Retomando uma das frases que citamos anteriormente, vemos Montaigne a dizer que a alma "deve alimentar-se apenas de si", mas "pode ver e sentir todas as coisas" (III, 10, 1009, grifos nossos). Ainda que não seja definido com clareza ao longo do ensaio, o termo paixão indica o impulso que compromete a tranquilidade do agente, impede-o de agir e põe em xeque sua liberdade. É somente este impulso (um impulso excessivo) que deve ser evitado por meio da terapia da diversão, a qual abre caminho para uma ação tanto mais plena, equilibrada, justa e eficaz. Neste sentido, poderíamos admitir que Montaigne experimenta uma ambição morna e discreta, que ele busca a honra sem ansiedade, sem 
paixão - sem prender-se a este outro e escravizar-se a ele. E se seus argumentos pareceram frequentemente radicais ao longo da trama do ensaio, a ponto de nos fazer crer que atacavam a ambição e a afetividade tout court, isto se deve ao fato de que tinham como alvo um excesso - a cultura da ação notável, tão característica da época. Contra um excesso, apenas outro é eficaz - apenas o outro extremo é capaz de reconduzir à justa medida: como na "arte dos arqueiros, que para chegar ao ponto vão buscando a mira num grande espaço acima do alvo" (III, 10, 1006).

\section{Montaigne Agente}

Se isto é verdade, se Montaigne assegura, por meio de uma busca morna da honra, sua tranquilidade e sua capacidade de ação, somos obrigados, por fim, a indagar os comentadores que defendem a tese da passividade do autor dos Ensaios ou que pretendem restringir o alcance de suas ações. Pensamos mesmo num grande clássico do comentário montaigniano, como o livro Montaigne, de Hugo Friedrich, que fez história com sua preciosa contribuição para o estudo da obra montaigniana e marcou diversos intérpretes posteriores ${ }^{23}$.

\footnotetext{
${ }^{23}$ Vemos certa proximidade, por exemplo, entre as consequências que Frédéric Brahami tira da crítica cética montaigniana no seu livro Le Scepticisme de Montaigne e as que Friedrich extrai de sua leitura da Apologia a Raimond Sebond. Embora com diferentes matizes, os dois comentadores caminham na direção de um irracionalismo de tipo vitalista que, no caso de Friedrich, assenta-se - como sugerem suas constantes alusões a Goethe, Dilthey, Burckhardt e mesmo Nietzsche - em pressupostos de certa tradição do pensamento alemão.
} 
Friedrich insere sua leitura ${ }^{24}$ do ensaio "De poupar a própria vontade" no segundo momento do movimento dialético de humilhação e afirmação do homem, que ele acredita presidir a estrutura dos Ensaios. Ele considera que Montaigne fornece com sua atuação política mais um exemplo da afirmação da condição humana - frágil, contingente, complexa, mistura de bem e mal, razão e paixão. Segundo o comentador, o ensaísta restringiria ao máximo sua aplicação aos cargos públicos (obrigação que se Ihe imporia) em nome de uma "livre disposição de si mesmo" (do máximo de espaço que pode conceder às próprias pulsões); optaria por um grau mínimo de intervenção sobre a ordem política em nome de um 'deixar correr' que, no final das contas, convergiria favoravelmente com $\mathrm{o}$ andamento do mundo, o qual seria avesso às intervenções. Nesta concessão mínima à obrigação dos cargos - entende Friedrich - Montaigne se ajustaria à sua condição humana mista: à sua precariedade (sua necessidade de segurança e, portanto, de uma vida em comunidade) e, ao mesmo tempo, às pulsões que lhe comandam o espírito, ansioso por liberdade.

Ocorre que esta concessão mínima à cidade, esta quase inação, este 'deixar correr' passivo em que o indivíduo atende sobretudo às suas próprias exigências e, por aí mesmo, ajusta sua conduta ao andamento do cosmos, vão na direção contrária do que Montaigne sustenta no "De poupar a própria vontade". Em primeiro lugar, porque a dosagem de sua aplicação aos cargos políticos não se funda numa necessidade (aliás, típica do individualismo moderno, que Montaigne, para Friedrich, inaugura) de dar livre curso às próprias pulsões, mas numa exigência ética herdada da tradição helenística - a

${ }^{24}$ Cf. Montaigne, pps. 261-265. 
tranquillitas. De tal modo que é uma outra ação, um outro trabalho - ação ou trabalho sobre si - que vêm regular a ação política. Em segundo lugar, porque mesmo a exigência ética não vem restringir o espaço da atuação política, mas, ao contrário, ampliá-lo, vindo fortalecer a ação com vistas à coletividade, tornála mais justa e eficaz. Isto porque se trata de afastar a paixão do domínio da ação. De tal forma que, tanto do lado da ética quanto da política, o ensaísta age - ainda que sobre uma matéria que pede cautela, observação, atenção aos seus próprios movimentos e exigências. É justamente por isso que Montaigne parece passivo: porque respeita rigorosamente a dinâmica de suas próprias pulsões bem como a das pulsões dos homens na história. Mas, o faz somente para adaptar a terapia à matéria, a ação ao objeto; pois, ele não deixa os eventos correrem - apenas observa-os, buscando aprender a maneira correta de agir e esperando o momento propício para intervir, calma e discretamente. 


\section{Conclusão}

Ao longo das páginas precedentes, procuramos reconstituir a trama argumentativa de dois ensaios montaignianos com vistas a afastar a imagem de passividade atribuída ao ensaísta frequentemente e de maneira equivocada por boa parte do comentário dos Ensaios. Sobretudo, procuramos mostrar justamente nos ensaios em que o autor mais parece passivo (naqueles em que os intérpretes mais reconhecem um Montaigne 'entregue aos próprios afetos') a permanência de uma ação discreta, conveniente. Procuramos mostrar que, embora Montaigne se reconheça incapaz da fortaleza ou da indiferença do sábio (da patientia ou da constantia, as duas modalidades de virtude que Sêneca descreve no De constantia sapientis), nem por isso ele se deixa levar pelos afetos, ao menos não quando não é conveniente (pois há circunstâncias, como mostramos em nossa análise do ensaio Da vaidade, em que as exigências da razão e as da paixão coincidem, e "suyvre le vent" é o melhor a ser feito).

Em nossa leitura do ensaio Da vaidade, procuramos reconstituir a crítica que Montaigne dirige à indiferença do sábio, ideal de virtude que ele se recusa a tomar como modelo de suas próprias ações. Isto porque a paixão é um fato incontornável. Sempre alguma coisa há de despertar em nós os arroubos da cólera, prostrar-nos sob o peso da melancolia ou aterrorizar-nos. É impossível permanecermos indiferentes às "coisas exteriores". Em De poupar a própria vontade, Montaigne recusa um segundo modelo de virtude: a patientia, a fortaleza diante das pressões da paixão. Uma vez diante dos objetos que despertam nele a cólera, a tristeza, o medo etc., Montaigne não consegue deixar de ser arrastado; reconhece-se fraco, incapaz de fazer frente à violência 
dos afetos. Isto não significa, no entanto, que ele aceite a servidão às paixões. Uma vez que tenha recusado os modelos de virtude de que se reconhece incapaz, Montaigne pode formular uma terapia adequada às suas próprias capacidades. Procuramos descrevê-la em nossa leitura do ensaio De poupar a própria vontade. Se o autor não pode permanecer indiferente aos bens e males de opinião nem fazer frente à pressão das paixões, pode ao menos tentar evitar o encontro com os objetos ou com as representações que as despertam. E caso esse encontro infeliz venha a ocorrer, pode desviar a própria consciência antes que as paixões ganhem corpo.

Acreditamos, assim, ter explicitado todo o esforço do autor para manterse ativo, senhor em alguma medida de suas próprias ações (enfim, para escapar da servidão das paixões). O ensaio De poupar a própria vontade é notável neste sentido. Contrariamente ao que pensa Hugo Friedrich, que vê neste texto uma espécie de recusa da ação ou uma concessão mínima à atividade (Montaigne dedicando-se o mínimo possível aos seus deveres na prefeitura de Bordeaux em nome de um 'deixar correr' que, no final das contas, convergiria favoravelmente com 0 andamento do mundo ${ }^{25}$ ), a recusa montaigniana da dedicação excessiva aos assuntos políticos visa evitar uma paixão: a ambição, afeto que tantas vezes move às escondidas os homens engajados. A atuação comedida de Montaigne à frente da cidade (seus mandatos discretos que não deixaram nenhum grande feito) visava evitar um duplo perigo: a perda da própria liberdade (a escravidão à busca da honra) e a dissolução da frágil ordem política que ainda subsistia sob as pressões das guerras de religião, mas que talvez não resistisse a outras inovações que

${ }^{25}$ Cf. Montaigne, pps. 261-265 
pretendessem ficar marcadas na história. Todo o ensaio De poupar a própria vontade, enfim, é marcado por uma exigência de ação, mas de uma ação conveniente, discreta, adequada às exigências próprias de seu objeto.

No ensaio Da vaidade, as paixões aparecem de maneira diferente; nele, Montaigne não tanto as evita como entrega-se a elas. Pressionado pelos aborrecimentos com a administração da casa, pelo horror que the provoca a visão da perfídia e pelo medo de ser sua próxima vítima, Montaigne se lança em viagem, afasta-se dos motivos de tormento e busca um pouco de alegria e de prazer noutras paragens. Neste ponto, os defensores de um Montaigne passivo comemoram: eis a prova de que tinham razão. Ocorre que Montaigne não se entrega às paixões propriamente, mas concede-lhes espaço quando reconhece ser oportuno. Quando analisa os deveres que se Ihe impõem na administração da casa e na vida pública, o ensaísta percebe que há circunstâncias em que os mesmos deixam-Ihe um espaço de liberdade em que pode dar vazão aos afetos. Assim, se a administração dos próprios bens aborrece-Ihe, Montaigne percebe que pode afrouxar um pouco o controle sobre suas finanças, lançar-se de vez em quando em viagem e negligenciar aqui e ali os próprios negócios, pois o dever que se lhe impõe é sobretudo não empobrecer e não exatamente enriquecer - objetivo que facilmente o conduziria ao vício da cupidez. Da mesma forma, percebe que não apenas pode como deve fazer vista grossa para os pequenos furtos dos servos, pois a preservação da fides no seio da família (o estreitamento dos laços desta pequena coletividade que é a casa) sobrepõe-se à administração dos bens. Não apenas as circunstâncias oportunas, mas mesmo a sobreposição dos 
deveres abre algumas brechas em que a concessão às paixões torna-se possível.

O mesmo vale para a vida pública. Quando Montaigne escreve o ensaio Da vaidade, o conflito entre católicos e protestantes já tinha assumido há muito tempo a forma da guerra civil. O Estado francês encontrava-se à beira do colapso. A Reforma Protestante havia abalado suas bases e a prática generalizada da perfídia lentamente esgarçava o tecido social, então prestes a se romper. Diante deste quadro caótico, qualquer intervenção direta sobre a ordem pública (qualquer tentativa de corrigir ou mudar seus rumos) não somente seria inútil como ainda perniciosa. O Estado francês encontrava-se à beira da dissolução justamente porque uma primeira inovação veio romper a ordem lentamente forjada pelo trabalho paciente dos costumes. Qualquer ação que pretendesse alterar novamente o estado das coisas arriscaria pôr a perder o resquício de ordem que ainda havia e apressar o colapso. Sobretudo na medida em que esta ação assumisse a forma da perfídia, suposto remédio amargo que os maquiavelianos acreditam ter lugar em circunstâncias extremas, mas que Montaigne entende acelerar o processo que ela justamente pretenderia corrigir. Num tempo em que todos pretendem se destacar por meio de inovações, em que todos pretendem salvar o Estado administrando-Ihe o veneno da quebra da palavra dada, Montaigne se afasta, concede espaço ao seu desejo de viajar. Mas não por passividade, e sim porque entende a ação política sobre outras bases que as da inovação e da perfídia.

Deste modo, contra as leituras da passividade montaigniana, procuramos mostrar as estratégias que o autor dos Ensaios elabora para escapar da servidão das paixões, bem como o senso de conveniência através 
do qual ele reconhece as ocasiões em que pode conceder-Ihes espaço. Procuramos, enfim, recuperar minimamente a conciliação muito feliz que o autor estabelece entre dever e prazer, razão e paixão, as imposições da coletividade e suas próprias exigências individuais. Noutras palavras, procuramos recuperar, para além da dimensão afetiva dos Ensaios, também incorporada em nossa leitura, sua dimensão normativa (a ética que se desenha ao longo de suas páginas), a qual foi rifada pelos comentadores que só vêem na obra montaigniana a descrição de uma singularidade que dá vazão aos próprios afetos e, no máximo, cede pragmaticamente às exigências das leis e dos costumes. Procuramos, enfim, criar condições para uma apreciação mais justa dos termos em que se dá esta ética.

Podemos indicar, a título de esboço, o modo pelo qual acreditamos estruturar-se esta ética dos Ensaios que, segundo pensamos, apóia-se em certos pilares: a experiência de si, os costumes e valores tradicionais, o comércio com os homens (a prática da conversação e o estudo da História) e as opiniões reputadas legadas pela tradição da Filosofia Moral ocidental. A experiência de si é o que fornece a Montaigne uma clara percepção das suas possibilidades. É ela que lhe ensina sua própria fraqueza, sua mediocridade e, por contraste, a inutilidade ou vaidade dos modelos de sabedoria e virtude (a patientia e a constantia) que não se lhe aplicam. Diante dessa fragilidade constitutiva que ele percebe em si mesmo (de sua incapacidade para se alçar à ciência e à virtude), Montaigne segue os costumes, que the aparecem como a única fonte normativa que resta, e que dá forma tanto aos indivíduos quanto à sociedade. Ocorre que Montaigne é um homem instruído, alguém longamente formado pelo comércio com os homens do presente (a prática da conversação) 
e do passado (a leitura da história), bem como pelo estudo da Filosofia Moral. Ele é um homem cujo juízo foi forjado pela conversação e pela leitura dos historiadores (que Ihe ensinaram a discernir as razões das ações dos homens) e pelos moralistas (que despertaram nele o amor pelas virtudes). Ainda que tardiamente, Montaigne é o homem que realiza de alguma forma o programa de estudos que ele próprio propõe para Diane de Foix no ensaio Da educação das crianças: "Je n'ay dressé commerce avec aucun livre solide, sinon Plutarque et Seneque (I, 26, p. 146); "je ne sçache point meilleure escolle (...) à former la vie que de luy proposer incessamment la diversité de tant d'autres vies, fantasies et usances" (III, 9, p. 973). Suas leituras, viagens e conversações forjaram seu juízo, tornaram-no apto a escolher e a julgar bem e mesmo a reconhecer quando os costumes vão de encontro ao bem (à justiça, à fidelidade, à generosidade etc.). A institution não Ihe deu o "Conhecimento do Bem" nem de nenhuma das virtudes, mas deu-lhe um senso que the permite regrar seu próprio comportamento.

Precisemos um pouco melhor o que queremos dizer. Montaigne segue os costumes e as leis, afinal, este é o único parâmetro de conduta objetivo que resta, não havendo nenhum Bem, Razão ou Natureza Humana sobre os quais fundar o próprio comportamento. Na medida em que o eu profere apenas opiniões, recusar-se a seguir as leis e os costumes em nome de uma pretensa autonomia traria um enorme perigo político: seria o equivalente a avalizar a anarquia. Ocorre que Montaigne é um homem de boas opiniões (a todo momento nos Ensaios ele provoca o leitor para que as julgue por si mesmo e confira se seus juízos são ou não acertados). De tal forma que Montaigne em geral segue os costumes, mas aqui e ali ele aponta equívocos e recusa-se a 
seguir o comportamento da maioria, contrapondo aos usos o seu senso de conveniência. É o que ele faz o tempo todo nos dois ensaios que analisamos. Se Montaigne seguisse estritamente os costumes e o que recomenda a opinião geral, ele não se permitiria viajar durante a velhice, pois se arriscaria a não cumprir com o dever de se despedir dos amigos e da família; ele se aplicaria rigorosamente à gestão dos bens (o que aliás seu pai esperava) para aumentar o próprio patrimônio; evitaria afastar-se da família e da esposa, em relação a qual tem deveres sexuais a cumprir; enfim, engajar-se-ia a fundo à frente da prefeitura de Bordeaux (tal como fizera seu pai), a ponto de compromoter a própria saúde e, provavelmente, a eficácia de suas ações.

De tal forma que parece difícil negar que o jugement de Montaigne intervém de alguma forma na composição de seu comportamento, fazendo de sua conduta algo mais complexo do que a simples anuência aos costumes imediatamente vigentes. Mas, quais seriam então os critérios sobre os quais se apóia o juízo montaigniano? Talvez costumes ou valores mais antigos, que os homens do presente teriam abandonado ("on peut s'opposer à ce que l'alteration et corruption naturelle à toutes choses ne nous esloingne trop de nos commencemens et principes." - III, 9, 958). Talvez valores imemoriais, crenças, opiniões e costumes lentamente sedimentados ao longo das épocas, mas eventualmente esquecidos no presente, e que um homem instruído como Montaigne, através de suas leituras, experiências e conversações com outros homens instruídos, é capaz de resgatar das sombras, para lembrar aos homens do presente que estão se desviando da conduta adequada (que se esqueceram da modéstia, da moderação, da generosidade, da fidelidade, da justiça; enfim, do bem). Os valores, nesse sentido, não seriam entidades 
metafísicas desde sempre estabelecidas de maneira clara e distinta, mas a matéria bruta do que poderíamos chamar de cultura, da qual somente o homem de juízo (não o erudito pedante) é capaz de se apropriar e de atualizar.

Retornemos aos 'pilares' que indicamos há pouco para tentar dar um pouco mais de precisão às nossas idéias acerca da maneira pela qual acreditamos estruturar-se a ética dos Ensaios. Montaigne se descreve como um homem capaz de julgar e escolher bem. Seu juízo foi forjado por uma educação que inclui suas leituras (História, Filosofia Moral, Poesia etc.), a conversação com os homens e suas viagens. Tudo isso lhe permitiu penetrar e se apropriar do chamamos, mais acima, de cultura. Mas os valores que Montaigne pode discernir na cultura geral constituem apenas uma das referências a partir das quais ele regra seu comportamento. A outra, como já vimos, são os costumes imediatamente vigentes, que Montaigne segue na na maior parte dos casos. A terceira, enfim, é a experiência de si, que definimos como a ausculta de sua própria fraqueza moral, mas que também inclui a experiência de seu próprio corpo. Este, de fato, também é uma instância reguladora da conduta. A experiência da doença, da velhice, e a perspectiva para a qual elas apontam (a morte) põem dificuldades para o sujeito moral e exigem um certo tipo de resposta: novamente, nem a indiferença nem a fortaleza, mas o desvio da consciência. As dores, os apetites, enfim, tudo o que se aprende com a experiência psicofisiológica é contabilizado como parâmetro de conduta.

Avaliando, então, as linhas mais recentes do comentário montaigniano, poderíamos dizer que nos afastamos um pouco da perspectiva de André Tournon. Isto porque o comentador parece apostar demais numa autonomia 
montaigniana e, sobretudo, porque ele a entende na forma de uma fidelidade do autor à sua própria natureza individual ou singularidade. Para Tournon ${ }^{26}$, o essencial da obra montaigniana é o ensaio, procedimento por meio do qual Montaigne toma a si mesmo como "objeto" de suas investigações e elabora uma "ética inovadora"27. Antes de mais nada, os Ensaios são "ensaios do juízo", isto é, exercícios de julgamento acerca das mais variadas matérias (das predileções poéticas do autor ao tratamento dado aos índios no Novo Mundo, de suas aventuras amorosas na juventude à disputa entre católicos e protestantes nas guerras de religião). Ao registrar suas opiniões ao longo das páginas de seu livro e, sobretudo, ao retomá-las e acrescentar-lhes novas observações, Montaigne pode discernir seus próprios procedimentos intelectuais e opções morais e, através deles, chegar a uma imagem fiel de si mesmo (que ele dá a conhecer ao leitor): um homem de condição comum, sem ciência, somente mais cioso em ter uma clara visão de si mesmo ${ }^{28}$. A primeira grande novidade de Montaigne, dessa forma, seria o gênero que ele inaugura, que realizaria pela primeira vez "uma espécie de redução fenomenológica, reorientando a investigação do objeto para o sujeito, do veredito sobre o fato para a instância de julgamento"29.

Mas a "inovação montaigniana", de acordo com Tournon, iria ainda mais além, visto que o procedimento do ensaio permitiria ao autor desenvolver uma ética até então nunca elaborada: uma ética "da autonomia e da fidelidade a

\footnotetext{
${ }^{26}$ Tournon, A., Montaigne, São Paulo, Discurso Editorial, 2004

${ }^{27}$ Idem, ibid., p. 144.

28 Idem, ibid., p. 113.

${ }^{29}$ Idem, ibid., p. 114.
} 
$\mathrm{si}^{\mathrm{i} 30}$. Desde seus primeiros esboços, diz o comentador, os Ensaios norteariamse por um ideal de autonomia. A intenção inicial de Montaigne de dispor seus escritos em torno do Discurso da Servidão Voluntária de La Boétie seria uma prova disso. A "mensagem libertadora" do Discurso daria o sentido da obra montaigniana: meditações por meio das quais o autor se libertaria das opiniões estranhas ou as assumiria apenas na medida em que nelas provaria suas próprias convicções ${ }^{31}$. A crítica pirrônica empreendida na Apologia, diz o comentador, legitimaria a empreitada e estenderia seu alcance. Enfim, Montaigne encontraria no procedimento do ensaio (no registro de seus juízos e, através deles, de sua própria imagem) as normas de conduta com que se orientar: ao se registrar na obra, ele fixaria uma imagem que não poderia desmentir, revelando a si mesmo sua própria "natureza", isto é, sua singularidade, bem como tudo o que convém a sua saúde física e moral ${ }^{32}$. No final, Montaigne encontraria algo semelhante à sabedoria de um Sócrates que, após conhecer a si mesmo e a seus próprios limites (após aprender que nada sabe), reencontrara por reflexão a bondade espontânea do homem rústico. A grande novidade de Montaigne, completa Tournon, não estaria exatamente em suas conclusões, mas na caução que o ensaísta lhes dá: nem Deus, nem a Natureza, nem a essência do homem, mas ele próprio, isto é, sua palavra (os Ensaios pertencendo menos à ordem dos conhecimentos do que à ordem dos testemunhos $)^{33}$.

\footnotetext{
${ }^{30}$ Idem, ibid., p. 144.

${ }^{31}$ Idem, ibid., p. 150.

32 Idem, ibid., p. 151.

${ }^{33}$ Idem, ibid., p. 117.
} 
Apesar de todo o seu vigor e interesse, sobretudo pela articulação engenhosa que ela propõe para este duplo empreendimento que são os Ensaios, ao mesmo tempo fundadores de um gênero literário-filosófico e veículo de uma ética, tendemos a nos afastar um pouco da leitura que Tournon faz da obra montaigniana, sobretudo no que diz respeito aos modos e parâmetros que o ensaísta empregaria para regrar sua própria conduta. Isto porque Tournon nos parece ir um pouco longe demais em sua aposta na "autonomia" e na "fidelidade a si" montaignianas.

Em sua leitura do ensaio Da vaidade ${ }^{34}$, Tournon afirma que o "modo de pensamento" montaigniano "leva verdadeiramente em consideração a contingência e a aceita sem reserva", o que não significa que Montaigne "se deixa levar e desiste das preocupações éticas", mas que ele propõe uma nova ética, a "filosofia do ensaio, com as possibilidades de regramento que ela comporta" ${ }^{35}$. No lugar "de um conjunto de valores reputados universais e estáveis", Montaigne proporia uma "prática de reflexão, registrada e ratificada pela escrita dos Ensaios", através da qual ele poderia "reapropriar-se da própria vida e controlá-la, sem as condenações do arrependimento e a miragem da perfeição" ${ }^{\text {"36. }}$ O ensaio Da vaidade descreveria justamente este trabalho normativo da escrita, que "fixa uma imagem [do autor] para si mesmo, com valor de norma". "Não há mais necessidade de paradigmas: a fidelidade a si basta." Trata-se de "decifrar o que há de mais singular em si mesmo" e "de

\footnotetext{
${ }^{34}$ Tournon, "Action imparfaite de sa propre essence", in Route par Ailleurs, Le nouveau Langage des Essais, Paris, Honoré-Champion, 2006

${ }^{35}$ Idem, ibid., p. 159.

${ }^{36}$ Idem, ibid., p. 160.
} 
encontrar as vias que convém a sua natureza individual", completa Tournon ${ }^{37}$. O comentador insiste que essa "ética pessoal" não implica apenas a "libertação" dos modelos exteriores, mas tem como contraponto um "acréscimo de rigor moral", visto que Montaigne se veria obrigado, justamente para não ser tocado pela leis (pelas normas exteriores), a pôr "regras ainda mais estritas" para si mesmo ${ }^{38}$. Tudo se passa, então, como se Montaigne extraísse apenas de si mesmo (de sua própria "singularidade", da experiência ou imagem de si que a escrita fixa nos Ensaios) suas normas de conduta. Tournon parece então se aproximar de tantos outros comentadores (por exemplo, Auerbach e Friedrich) que vêem nos Ensaios a aurora do indivíduo moderno, de que Montaigne seria uma das primeiras figuras, ou pelo menos um esboço. Ocorre que, se o ensaísta confia tanto no seu juízo a ponto de fazer a crítica de certos costumes e condutas de seu tempo é porque ele se apropriou de toda uma tradição de pensamento e de cultura; é porque ele a fez sua, digerindo-a à sua maneira ("Les abeilles pillotent deçà delà les fleurs, mais elles en font apres le miel, qui est tout leur" - I, 26, 152). É somente neste sentido que podemos dizer que ele critica algumas condutas de sua época firmando-se sobre "si mesmo": apoiando-se sobre seu próprio juízo, Montaigne se assenta sobre boa parte da cultura ocidental (nada mais distante do indivíduo moderno, que pretende, este sim, fundar a ética e a ciência apenas sobre "si mesmo"). Uma passagem do ensaio Da vaidade é bastante ilustrativa do papel que o passado cultural tem para o autor, que demonstra gratidão por tudo o que recebeu do convívio com os homens do passado, e lhes retribui preservando sua memória:

\footnotetext{
${ }^{37}$ Idem, ibid., p. 161.

${ }^{38}$ Idem, ibid., p. 162.
} 
"J'ay veu ailleurs des maisons ruynées, et des statues, et du ciel, et de la terre: ce sont tousjours des hommes. Tout cela est vray; et si pourtant ne sçauroy revoir si souvent le tombeau de cette ville, si grande et si puissante, que je ne l'admire et revere. Le soing des morts nous est en recommandation. Or j'ay esté nourry dés mon enfance avec ceux icy; j'ay eu connoissance des affaires de Romme, long temps avant que je l'aye eue de ceux de ma maison: je sçavois le Capitole et son plant avant que je sceusse le Louvre, et le Tibre avant la Seine. J'ay eu plus en teste les conditions et fortunes de Lucullus, Metellus et Scipion, que je n'ay d'aucuns hommes des nostres. Ils sont trespassez. Si est bien mon pere, aussi entierement qu'eux, et s'est esloigné de moy et de la vie autant en dixhuict ans que ceux-là ont faict en seize cens; duquel pourtant je ne laisse pas d'embrasser et practiquer la memoire, l'amitié et societé, d'une parfaicte union et tres-vive." (III, 9, p. 996)

Montaigne, enfim, não pensa sozinho nem funda a ética apenas sobre si mesmo. Atrás dele há todo um cortejo de grandes homens. 


\section{REFERÊNCIAS BIBLIOGRÁFICAS}

ARGOD-DUTARD, FRANÇOISE (éd.). Des signes au sens: lectures du livre III des "Essais". Journées d'études du Centre Montaigne de Bordeaux, 1415 novembre 2002. Paris: Honoré Champion, 2003.

ARISTÓTELES - Éthique à Nicomaque, traduit par J. Tricot, Paris, Vrin, 1997.

AUERBACH, E. - “L'Humaine Condition”, in Mimesis: a realidade na literatura, Edusp/Perspectiva, São Paulo, 1971, pps. 245-270

BENDELAC, A. - Montaigne à la recherche d'un équilibre de relation entre le Moi et Autrui, in Bulletin de la Société Internationale des Amis de Montaigne, Vè série, n 17 (JANVIER-MARS 1976). pp. 31-48

BENSIMON, MARC. “Espace, Voyage, Écriture: 'De la vanité’”. In Montaigne: Espace, voyage, écriture, Actes du congrès international de Thessalonique, 23-25 septembre 1992. Paris: Honoré Champion, 1995.

BIGNOTTO, N. - "Montaigne renascentista”, in Kriterion - Revista de Filosofia, no. 86, Belo Horizonte, UFMG/FAFICH, 1992.

BIRCHAL, T. - Régard sur soi, l'esprit qui connaît: figures de la subjectivité chez Montaigne et Descartes. Montaigne Studies: an interdisciplinary forum, v. 25, p. 31-38, 2013.

- As razões de Montaigne. Sintese (Belo Horizonte.

1974), v. 33, p. 229-246, 2006. 
- Aquele que busca a Deus, o incrédulo e o honnêtehomme: natureza e sobrenatureza nestes três tipos de homem. Kriterion, v. XLVII, p. 335-346, 2006.

- Montaigne e a modernidade. Kriterion, Belo Horizonte, v. 86, p. 77-92, 1992.

- O Eu nos Ensaios de Montaigne. 1. ed. Belo Horizonte: Editora da UFMG, 2007. v. 1. 262p .

- Diante das diferenças: Montaigne e os limites da tolerância. In: José Alexandrino de Souza Filho. (Org.). Montaigne e seu tempo. 1ed.João Pessoa: Editora Universitária da UFPB, 2012, v. , p. 63-76.

- Sobre Auerbach e Montaigne: a pertinência da categoria de mímesis para a compreensão dos Ensaios. In: Rodrigo Duarte; Virgína Figueiredo. (Org.). Mímesis e Expressão. Belo Horizonte: Editora da UFMG, 2001, v. , p. 278-288.

- Montaigne e seus duplos: elementos para uma história da subjetividade. Tese de Doutorado, FFLCH-USP, mimeo, 2000.

BOUCHARD, PASCAL - Recherche sur la structure philosophique des essais 9 et 10 du livre III des Essais, in BSIAM, Vè série, $\mathrm{n}^{\circ}$ 10-11 (avrildécembre 1974). pp. 63-70

BRAHAMI, F. - Le Scepticisme de Montaigne, PUF, Paris, 1997 
BRAHAMI, FRÉDÉRIC ET NAYA, EMMANUEL (éd.). Montaigne et l'action, número especial do Bulletin de la Société des Amis de Montaigne, 8/17-18, 2000.

BRODY, JULES. "'De mesnager sa volonté': lecture philologique d'un essai". In O un amy! Essays on Montaigne in honor of Donald M. Frame. French Forum Publishers, 1977. Também In Lectures de Montaigne. Lexington: French Forum Publishers, 1982. pp. 28-54.

BRUN, JEAN - O Epicurismo, trad. Rui Pacheco, Lisboa, Edições 70, 1987

- O Estoicismo, trad. João Amado, Lisboa, Edições 70, 1986

CARDOSO, SÉRGIO - "O homem, um homem: do humanismo renascentista a Michel de Montaigne", in Perturbador Mundo Novo, Escuta, São Paulo, 1992

- "Uma fé, um rei, uma lei - A crise da razão política na França das Guerras de Religião", in A Crise da Razão, Companhia das Letras/Funarte, São Paulo, 1996.

- "Villey e Starobinski: duas interpretações exemplares sobre a gênese dos Ensaios", in Kriterion - Revista de Filosofia, vol. 23, no. 86, agosto/setembro de 1992.

- "Antigos, Modernos e Novos Mundos da Reflexão Política", in Novaes, A. (org.), A invenção do Estado Nação, Companhia das Letras, São Paulo, no prelo. 
- "Paixão da igualdade, paixão da liberdade: a amizade em Montaigne", in Novaes, A. (org.), Os Sentidos da Paixão, Companhia das Letras/Funarte, São Paulo, 2006 (13ª edição)

CARRAUD, VINCENT ET MARION, JEAN-LUC (éd.). Montaigne: scepticisme, métaphysique, théologie. Paris: PUF, 2004. (Coll. "Épiméthée")

CHARPENTIER, F. - "Ces poinctes eslevées de la Philosophie...": l'éthique des derniers essais", in Cahiers Textuel, 34-44, no. 2, 1986

COLOMBERO CARLO - Uomo e natura nella filosofia Del Rinascimento, Loescher, 1976

CONCHE, MARCEL. Montaigne ou la conscience heureuse. $5^{\mathrm{a}}$ ed. Paris: PUF, 2002.

CROQUETTE, BERNARD. Étude du livre III des "Essais" de Montaigne. Paris: Honoré Champion, 1985.

- Essais, livre III, chap. 9, "De la vanité". Paris: Éditions Pédagogie Moderne, 1981. ("Lectoguide second cycle")

DESAN, PHILIPPE (éd.). Montaigne politique. Actes du colloque international de l'université de Chicago (Paris, 29-30 avril 2005). Paris: Honoré Champion, 2006.

DUBOIS, CLAUDE-GILBERT. Essais sur Montaigne. La regulation de l'imaginaire. Éthique et politique. Caen: Paradigme, 1992. 
EVA, L. A. A. - Montaigne's Radical Skepticism. In: Maia Neto, J.R.; J.C. Laursen; G. Paganini. (Org.). Skepticism in the Modern Age. Building on the work of Richard Popkin.. 1ed.Leiden: Brill, 2009, v. 181, p. 83-106.

- A Figura do Filósofo - Ceticismo e Subjetividade em Montaigne. 1. ed. São Paulo: Edições Loyola, 2007. v. 1. 507p .

- Montaigne contra a vaidade. São Paulo: Editora Humanitas, 2004.

- Ceticismo e Paradoxo nos Ensaios de Montaigne, Tese de Doutoramento, FFLCH-USP, mimeo, 1999

- Notas sobre a Presença de Sêneca nos Ensaios de Montaigne. Educação e Filosofia, Uberlândia MG, v. 9, n.17, p. 39-52, 1995.

- "Montaigne e o ceticismo na Apologia de Raimond Sebond: a natureza dialética da crítica à vaidade", in O que nos faz pensar, 8 , nov. 1994, pps. 106-117

- A Vaidade de Montaigne. Discurso. Departamento de Filosofia da FFLCH da USP, USP, v. 23, p. 25-52, 1994.

- Montaigne e o ceticismo na Apologia de Raimond Sebond (mimeo), Dissertação de Mestrado defendida junto à FFLCH-USP, sob a orientação do Prof. Dr. Oswaldo Porchat, em março de 1994, 221p.

FRAME, DONALD M. - To 'Rise above humanity' and to 'Escape from the man': two moments in Montaigne's thought. (The Romanic review, LXII, no. 1, pp. 28-35; New York, 1971) 
FRIEDRICH, HUGO. Montaigne. Trad. de Robert Rovini. Paris: Gallimard, 1992. (coll. “Tel”)

GAUNA, MAX. Montaigne and the Ethics of Compassion. Lewiston, Queenston e Lampeter: E. Mellen, 2000.

GUTWIRTH, MARCEL. Michel de Montaigne, ou le pari d'exemplarité. Montréal: Presses de l'université de Montréal, 1977.

HADOT, P. - La citadelle intérieure. Introduction aux Pensées de Marc Aurèle, Fayard, Paris, 1992

HAY, CAMILLA HILL. Montaigne, lecteur et imitateur de Senèque. Poitiers: Université de Poitiers, 1938.

KRISTELLER, P. O. - Humanism and Scholasticism in the Renaissance, 'Byzantion', XVII, 1944-1945

- Otto pensatori del Rinascimento italiano (trad. it. di R. Federici), Milano-Napoli, Ricciardi, 1970

LANGER, ULLRICH (ed.). The Cambridge Companion to Montaigne. Cambridge: Cambridge University Press, 2005.

LEBRUN, GÉRARD - O conceito de paixão, in Novaes, A. (org.), Os Sentidos da Paixão, Companhia das Letras, 2006 (13ª edição), pps. 17-33

LEOPOLDO E SILVA, F. - "A referência a Montaigne na concepção pascaliana de história", in Kriterion - Revista de Filosofia, no. 86, Belo Horizonte, UFMG/FAFICH, 1992. 
LEVINE, ALAN. Sensual Philosophy: Toleration, Skepticism and Montaigne's Politic of the Self. Lanham Md.: Lexington Books, 2001.

LIDDLE, MICHEL - Montaigne et l'altérité, in BSIAM, VIlè série, n²9-3031-32 (juillet-décembre 1992 / janvier-juin 1993). pp. 161-168

LONG, ANTHONY - La Filosofia Helenística - Estoicos, Epicúreos, Escépticos, trad. P. Jordan de Urries, Madrid, Alianza Editorial, 1977.

MACLEAN, IAN. Montaigne philosophe. Paris: PUF, 1996. (coll. "Philosophies")

MATHIEU-CASTELLANI, GISĖLE. Montaigne ou la Vérité du mensonge. Genève: Droz, 2000.

MERLEAU-PONTY, MAURICE - "Leitura de Montaigne", in Sinais, tradução de M. E. G. Gomes Pereira, Martins Fontes, São Paulo, 1991

MICHEL, P. - Pour mieux lire le livre III des Essais. (Bulletin de la Société des amis de Montaigne, 4a. Sér., no. 12, pp. 9-24; Paris, 1967)

MONTAIGNE, MICHEL DE - Les Essais, Édition de Pierre Villey, reéditée par V. L. Saulnier; Col. Quadrige, PUF, Paris, 1999.

- Essais, Imprimerie Nationale Éditions,

Paris, 1998.

- Os Ensaios, Martins Fontes, São Paulo, 2001.

- Ensaios, trad. de Sérgio Milliet, Os Pensadores, Abril Cultural, São Paulo, 1980. 
NAKAM, GÉRALDE - "Les Essais" de Montaigne. Miroir et procès de leur temps. Témoignage historique et création littéraire. Paris: Nizet, 1984; Honoré Champion, 2001.

- Montaigne et son temps: les événements et les Essais. L'histoire, la vie, le livre. Paris: Nizet, 1982.

- Le Dernier Montaigne. Paris: Honoré Champion, 2002.

- "Langage de l'esprit, Langage du corps dans les derniers "essais" des Essais", in Montaigne, les derniers essais - Actes de la journée d'étude Montaigne; Textes réunis par Françoise Charpentier; UER Cahiers Textuel, 34-44, no. 2, Université Paris VII, Paris, 1986

- Montaigne maire de Bordeaux, à la mairie et dans les Essais, in BSIAM, Vlè série, n 13-14 (janvier-juin 1983). pp. 7-28

POUILLOUX, JEAN-YVES - La question de l'identité, in BSIAM, VIlè série, n 29-30-31-32 (juillet-décembre 1992 / janvier-juin 1993). pp. 153-160

- Montaigne. L'éveil de la pensée. Paris: Honoré Champion, 2002.

QUINT, DAVID. Montaigne and the Quality of Mercy: Ethical and Political Themes in the "Essais". Princeton University Press, 1998.

REGOSIN, RICHARD L. The Matter of My Book. Berkeley and Los Angeles: University of California Press, 1977. pp. 161-166. [Leitura de III, 9] 
SAMARAS, ZOÉ (éd.). Montaigne. Espace, voyage, écriture. Actes du congrès international de Thessalonique (23-25 septembre 1992). Paris: Honoré Champion, 2001.

- Le rôle de la fortune dans la pensée de Montaigne, in BSIAM, Vè série, $\mathrm{n}^{\circ}$ 10-11 (avril-décembre 1974). pp. 71-78

SCHAEFER, DAVID L. The Political Philosophy of Montaigne. Ithaca e Londres: Cornell University Press, 1990.

SCHMITT, CHARLES B. AND SKINNER, QUENTIN (eds.). The Cambridge History of Renaissance Philosophy. Cambridge: Cambridge University Press, 1998.

SCHNEEWIND, J. B. L'invention de l'autonomie, une histoire de la philosophie morale moderne. Paris: Gallimard, 2001.

- "Montaigne on moral philosophy and the good life". In The Cambridge Companion to Montaigne, ed. by Ullrich Langer. Cambridge: Cambridge University Press, 2005.

SCREECH, MICHAEL A. Montaigne et la mélancolie. La sagesse des “Essais". Paris: PUF, 1992.

SENECA - De Tranquillitate Animi, in Sénèque, Traités Philosophiques, vol. Il (texte établi, traduit et annoté par François et Pierre Richard), Paris, Librarie Garnier Frères, 1933 
- De Tranquillitate Animi, in Les Stoïciens (textes traduits par Émile Bréhier et édités sous la direction de Pierre-Maxime Schuhl), Paris, Gallimard, 1962

SÈVE, BERNARD. Montaigne. Des règles pour l'esprit. Paris: PUF, 2007. (coll. Philosophie d'aujourhui)

SMITH P. J. - "Continuar e conservar: Montaigne e o poder", in História: questões e debates (Depto. de História - UFPR), ano XIII, no. 25, pps. 58-81, jul.-dez. 1996

STAROBINSKI, JEAN. Montaigne en mouvement. Paris: Gallimard, 1993. (coll. "Folio")

TOURNON, ANDRÉ. Montaigne en toutes lettres. Paris: Bordas, 1989.

- Montaigne, la glose et l'essai. Éd. revue et corrigée. Paris: Honoré Champion, 2000.

- "Action imparfaite de sa propre essence". In Carraud, Vincent et Marion, Jean-Luc (éd.). Montaigne: scepticisme, métaphysique, théologie. Paris: PUF, 2004. P. 33-47.

VAN DELFT, LOUIS - Réflexion morale et économie du moi dans les Essais, in BSIAM, VIlè série, nº 19-20 (janvier-juin 1990). pp. 35-50

VASOLI, CESARE. "The Renaissance concept of philosophy". In Schmitt, Charles B. and Skinner, Quentin (eds.). The Cambridge History of Renaissance Philosophy. Cambridge: Cambridge University Press, 1998. pp. $57-74$. 
VILLEY, P. - Les sources et l'évolution des Essais de Montaigne, Osnabrück: Otto Zeller, 1976 (reimpressão da 2a. edição de 1933, Paris, Librairie Hachette)

- Les Essais de Montaigne, col. "Les Grands évènements littéraires", Nizet, Paris, 1992

- Montaigne et Francis Bacon, Slatkine Reprints, Genève, 1973

XENOFONTE - Econômico (trad. Anna Lia Amaral de Almeida Prado), São Paulo, Martins Fontes, 1999. 